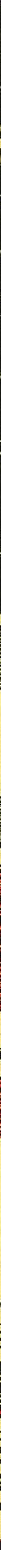

Tauno Saarela

simnissh communissm vissited 
Finnish communism visited 



\author{
Tauno Saarela
}

\title{
Finnish communism visited
}

The Finnish Society for Labour History

Papers on Labour History VII

Helsinki 2015 
The Finnish Society for Labour History 2015

() Tauno Saarela

Layout: Raimo Parikka

Kannen kuva: L. Vickberg, Nuoren Työläisen Joulu 1921

ISBN 978-952-5976-18-2

ISBN 978-952-5976-19-9

Hansaprint Vantaa 2015 


\section{Contents}

Introduction

Finnish and international communism

International and national in the communist movement 13

Finnish communism, bolshevization and stalinization

Comparative communisms: The Nordic example

Nordic communists in the Communist International

American impact on Finnish communism in the 1920s

109

Cultural communism

Class struggle in the cemetery

Oppressed worker or communist hero? Characters in Finnish communist magazines of the 1920s

Finnish communist youth and popular music, 1944-1969 167

Leader cults

Dead martyrs and living leaders: the cult of the individual within Finnish communism

Kuusinen vs. Mannerheim - Finnish leader cults in comparison

Dates and sources of original publications 



\section{Introduction}

Centralization and unity are words often connected with communism. The international communist movement indeed followed principles of centralization and thrived for unity. It has, however, been a subject of constant controversy, how successful it was in these attempts.

I have not been enthusiastic over emphasising the success of centralization. That is probably due to my experience of the communist movement but also to my academic training. In my first academic work I studied the relations between Finnish socialist intellectuals and the Communist Party of Finland in the 1930s. My intention was to challenge straightforward claims about the dominance of the communist party over these intellectuals. The dominance was usually substantiated by the fact that those intellectuals used concepts regarded as communist. A careful reading of the contents and meanings of these concepts in the context of various socialist tendencies, however, revealed that the socialist intellectuals rather found their ideological models in the ideas of Austrian and German left-socialists as well as leftists of the Second International. This study taught me that there can be differences within seeming unity. It also taught me to be interested in differences.

I did not give up those lessons in my proper studies of Finnish communism. When I drafted my outlines for studying communism in the early 1990s, I was much more interested in differences than similarities. I thought that the conditions of the country, the traditions of the labour movement had a strong impact on the agendas of the communist movements and made following of centralized instructions difficult. These varying conditions would also influence on the interpretation of these instructions. These guidelines can be found in the first article of this book, published 
in 1998. I have been rather loyal for those guidelines. That becomes evident in the other articles of this book but above all in my Finnish books Suomalaisen kommunismin synty 1918-1923 (Birth of Finnish communism, 1918-1923, (1996)), Suomalainen kommunismi ja vallankumous, 1923-1930 (Finnish communism and revolution, 1923-1930, (2008)) sekä Kansan Tahto. Pohjolan työtätekevien lehti (Kansan Tahto. The newspaper of the northern working people, (2006))

In addition to the guidelines, the articles of the book portray Finnish communist movement as an example concerning the relations between national and international in the communist movement. Finnish communism is also studied in relation to the instructions of the international communist movement and to other Nordic communist movements. One of the articles deals with the American impacts on Finnish communism. In general, the articles tell that there could be differences within one national communist movement.

Besides Finnish communism in a wider context, the articles deal with cultural aspects of Finnish communism. My interest in cultural issues is not merely cultural but has a strong connection with the political questions; by participating in the interpretation of cultural life the communist movement was struggling over political power. The leader cults, dealt with in the articles of the book, had also to do with power, but rather to maintain than to conquer it.

Seven of the articles have been published in other forums earlier; three of them have been presented as conference papers. As the articles were originally published in various forums, and as they were separated pieces on Finnish communism, it was necessary to give a short explanation of the formation and character of the movement. So, as the articles are published unchanged, there is repetition in their introductions. When the formation of Finnish communism in two countries starts to become boring, skip the introductions and proceed directly to the substance of the articles. 
The articles of the book give only a glimpse of Finnish communism, which was, on the basis of the success in parliamentary elections, among the strongest communist movements in Europe, and would deserve a more comprehensive book in English.

I thank the Finnish Society for Labour History for including my texts in their publication series. I also thank my British friends, Kevin Morgan, Norman LaPorte and Matthew Worley, who have encouraged me to publish in English and very often also found a forum for publication.

Publication of an article collection may give an impression that my vitality and interest in Finnish communism is coming to an end. I hope not.

Helsinki 15 March 2015

Tauno Saarela 



\section{Finnish and international}





\title{
International and national in the communist movement
}

\author{
A complex relation
}

In 1981 Perry Anderson stated that the dialectic between the international and national determinants of Communist party policies was a complex on ${ }^{1}$.

The problem is older than the communist movement. Its origins may be found in the thoughts of Karl Marx and Friedrich Engels. They had urged the workers of the world to unite in their struggle against the bourgeoisie but, on the other hand, they identified the nation states as forums for this struggle. It should, thus, be international in its contents and national in its form.

In Marx's time, the definition of this relationship was not put to the test. But with the advent of mass parties in the last decades of the 19th and the first decade of the 20th century it started to become clear that the workers were actively supporting their nations in many ways. This involvement was more evident at the outbreak of the First World War in August 1914, when many parties supported the war policies of their countries.

The Communist International (Comintern) was founded to solve the problems of the Second International. Lenin and other Bolsheviks thought they could overcome the problem between the international content and the national form of the working class struggle by creating a centralized International. The Second International had been only "a union of national parties", the Communist International was to become a coherent international party, "a world party". It was thought that activism in support 
of the nation states could be prevented by demanding absolute loyalty to the ideological, political and organizational "directives" given by the International. ${ }^{2}$

How well the Communist International succeeded has been the subject of constant controversy. When writing of the complexity of the relations between international and national determinants, Perry Anderson was commenting on the historiography of the communist movement. All of his predecessors didn't regard the relations as being this complex.

First, there were the studies that wanted to emphasize the international side of the relation. This group includes both the Cold War histories, which had a tendency to portray national communist parties as puppets of Moscow and communism as a Soviet conspiracy, and the loyal party histories.

A response to that trend were the studies which wanted to study communist parties almost entirely in relation to their own nations. These included also histories written by former party functionaries in the late 1960s and early 1970s. They ignored the connections with the International, and the context in these books could only seemingly he that of the own nation, but rather that of the party theory. ${ }^{3}$

The relation between the national and international determinants was pondered more thoroughly in the 1980s, as the article by Anderson indicates. A careful consideration of this complex relation was also evident in many books ${ }^{4}$. But in the 1980s some historians also expressed their concern at the disappearance of communism in the studies of communism, and at the birth of studies of communism without communism.

This concern reflected the strengthening of the social historical approach and the neglect of political and international aspects, as the communist parties were studied only in the context of their nations. ${ }^{5}$ The important result of these discussions was the realization that the determination of the character of the Communist parties depended very much on the context and the arguments for it. ${ }^{6}$ This argument finds a strong support in many recent stud- 
ies that have questioned the straight line between the leaderships and the members of the parties. ${ }^{7}$

After the opening of the Moscow archives the discussion of the contexts abated, while studies on communism have experienced a revival. The main themes in this revival have been those concerning the fate of national communists in the Soviet Union in the 1930s; relations between the Comintern and national parties; mechanisms of the Comintern central apparatus; and relations between Stalin, the Communist Party of the Soviet Union and the Comintern.

These studies have revealed the strong grip of the Russians and Stalin in the Comintern beginning in the late 1920s, and perhaps also strengthened the idea of a centralized communism, even though that would not have been the intention. The opening of the Moscow archives has also contributed to studies concentrating on daily politics and leadership or Russian context. ${ }^{8}$

Nowadays, political scientists are ready to admit that during the Cold War it was usual to give local conflicts world-wide significance, to see political conflicts as moral and relative differences as absolute. It was also usual that "in the glory days of the Cold War, each side attributed to the other a master plan for world domination joined with diabolitical efficiency in executing the plan". ${ }^{9}$

That is exactly what the Comintern did from the very beginning. However, the time has come to assess the efficiency of the Comintern and the extent to which it was able to guide political activities without taking into consideration also the ideological and cultural aspects of the movement.

\section{Imagined communities?}

It has been said that the nation is an imagined community. Furthermore, it has been argued that national identity is a discoursive entity concerning which various social groups and individuals have their own ideas. This discoursive entity is formed in a 
historical process; it is produced and reproduced again and again in various situations.

These arguments, with the acceptance of various contexts, could be helpful in approaching the history of the communist movement - or they could make it more complicated. Communism could be regarded as a discourse that was not immediately, if ever, final, but which began to take shape with the founding of the international communist movement. It was not created by the Bolsheviks alone, though they were in a privileged position and wanted to make their ideas universal, but also by communists in other countries. Within this discourse there were interpretations and changes of significance, and they were also due to various conditions and traditions.

In other words, the communist movement was, as were other political movements and doctrines, a place where various international and national impacts confronted each other and were interpretated. The national and international determinants were, however, not the same at various levels; they were not the same in Moscow, or in London, Paris and Helsinki, or in local communities, which even had a communist majority, as was the case in Karkkila and Oulujoki in Finland. The interpretations varied according to place and time, and they were not the same at the ideological, political and cultural levels of the movement.

Since, according to this conception, the interpretation depends on the place, more attention should be paid to analysing those worlds the communists lived in. And, in this analysis, the writings of Quentin Skinner and Dominick LaCapra, among others, about the interpretation of texts are useful. According to them, the ideas and the concepts presented in writings and speeches get their meaning against the social and linguistic context of the writer or speaker. These contexts include, for example, social and political conditions and situations, their ideologies and discourses, and the intentions and the past of the writer. ${ }^{10}$

This also provides the basis for the argument that ideas, concepts and directions are transformed when they move from one country and from one person to another. This was the case in the 
labour movement before the First World War. The ideas and concepts were transformed when they moved from the metropolises of the movement to other countries. ${ }^{11}$ In spite of calls for centralism and discipline, this state of affairs was not changed by the Communist International. The reception of ideas and concepts was not, even for communists, a passive occurrence; rather national communists interpreted new ideas and concepts through their past ${ }^{12}$. The further the International and the national headquarters were from the local communists, the more abstract the unity and solidarity.

\section{Engagement or isolation?}

The contexts of the Communist International in Moscow and the various national parties were not the same. The starting points for the International were the expectations and preparation of revolutions in Central Europe or in the colonial countries on the one hand, and the internal needs and security interests of Soviet Russia/the Soviet Union on the other hand. Their role in the decision-making of the International varied depending on the point in time. On the other hand, the situations in other countries brought other questions into the agendas of the Communist International. More constant features in the activities of the International were the attempts to get all the national parties to act according to accepted directions and ideas. Through them the Bolsheviks strengthened their grip in the International, and the various national interests were gradually redefined in terms of the international interests of the communist movement. ${ }^{13}$

Even from the perspective of revolution, the national communist parties faced a contradictory task. They were supposed to seize the power in their nations, and for carrying out this task they had, at least, to consider whether the conditions were favourable for the seizure of power. For this, it was necessary to know whether the workers would support communists, and in order to secure their support the movements had to pay attention 
to the day-to-day interests of the workers. Furthermore, they had to estimate the strength and attitudes of other social groups and parties. All this demanded an orientation according to the particular conditions prevailing in their own country.

On the other hand, the national communist parties, especially after the failure of the immediate world revolution, had to maintain the belief in the certainty of the coming revolution. That required the protection of the workers, particularly their own members and supporters, against the influence of other ideas, and this created a tendency towards the isolation of national communist movements.

In the national parties there were also two tendencies regarding the definition of communism. On one hand there were the old traditions and practices of the workers' movement, and on the other, the efforts of the Communist International, accepted also in many respects by the national parties, to make all the communist parties bearers of communism as defined by the International.

All of these tendencies converged under certain political circumstances. The communists were not the only actors in the nation states; they were seldom able to define their agendas and instead had to respond to issues launched by others or to become marginalised and thus mere agitators of the communist doctrines. ${ }^{14}$ Consequently, the ideas and activities of those who ruled nation states set limits for national communisms.

The tasks and status of the national communist movements were especially hampered by the birth of new nation states after the First World War. In these new nation states anti-communism often became an important theme in the creation of national identity. In Finland, for example, because of the interpretations of the Civil War waged in winter and spring 1918 and the close proximity of Soviet Russia/the Soviet Union, anti-communism was a central element in the thinking of many social and political groups. Therefore, communism was a more important issue in national politics than the size and status of Finnish communism would otherwise have justified. 
The restrictions placed by the governments on communism also helped to determine the ways in which the various national communisms manifested themselves. The conditions for communist activities were much weaker in those countries where political discourse and organisation and criticism of the authorities were restricted, even criminalised, compared e.g. with constitutionalist Britain, even though publishing of the resolutions of the Comintern was sometimes criminalised even there. The restrictions usually strengthened the tendency of isolation within the national communisms. This isolation didn't necessarily mean the withering away of the movement, as the Italian and Finnish cases demonstrate.

National and international aspects were not the same in every national communism. In Finland, the division of the labour movement and the birth of Finnish communism were, in a lasting and complicated way, associated with the interpretation of the Civil War. In addition, some of the traditions of the earlier Finnish labour movement were also strongly present in Finnish communism. Its strength and survival despite great difficulties was closely linked to its involvement with domestic issues and sources of discontent which could and would not find other channels.

Differences in the societies and in the traditions of the labour movements were also reflected in the character of the movements. In the 1920s, the support of communist movements in Germany and in Finland, measured by the results of parliamentary elections, was equal, about $13 \%$ at its best, and given their status in the trade unions, Finnish communism might even have been stronger than German communism.

Their activities in the national politics were, however, quite different. In Germany, the Communist Party of Germany (KPD) tried on many occasions to agitate against the state, in Finland, Finnish communism was, with some exceptions, rather more interested in finding shelter from the outside world than in fighting in the streets. There are many reasons for these differences in social structures and situations. For the Finns, the bitter defeat in the Civil War was crucial. But the differences also reflect different 
priorities; from the perspective of the Comintern, Germany was central, Finland peripherial. ${ }^{15}$

Of the tendencies in the national communisms, the one of isolation was usually stronger. The attempts of the International to strengthen its hold of the national parties contributed to the same tendency. Perhaps the Comintern was indeed working toward complete isolation, though its leaders didn't shout for joy, when most of the Communist parties were underground by the early 1930s.

There might be a tendency that the national Communist parties that were effectively isolated from the outside world were more likely to have found support from the International; they were compensated for their national weakness by the International.

The leaderships of the underground parties, which often had their headquarters in the Soviet Union, could also have been more inclined to accept eagerly the instructions of the Communist International. At least, the central committee of the Communist Party of Finland (SKP) was a good example of that.

\section{Continuity versus ruptures}

It has been usual to periodise the history of the Communist International, or rather its central apparatus, according to the changes in its main political slogans. ${ }^{16}$ These changes were certainly important in respect to the activities of the International, but they also demonstrate something else, namely repeated attempts to define communism and to adapt its institutions to changing political situations. The repeated criticism directed toward the national parties gives also grounds to wonder, whether the international communist movement had any clear idea of its politics.

The conception of the history of international communist movement as series of reorientations is supported by other periodisations. On the basis of the relation between international and national aspects it is possible to discern three phases. 
The first phase, the post-war years 1918-1920, could be characterized by the hope that an international army of the proletariat would sweep capitalism away. During this brief, early period no national interests were very relevant in defining the international. During the second phase, from 1920 onwards, the national interests of the Soviet Russia and Bolsheviks began to transform into the international interests of the international and national communist movement. The launching of the Popular Front in 1935 brought yet another change when the communist parties received a permission to orientate themselves to the national traditions, or rather to compete with them. This competition was evident in some national movements from the very beginning, although there was no encouragement from the International.

All this is not to say there were no elements of continuity in the international communist movement, be they ideas concerning the communists' own role, their identity or their enemies ${ }^{17}$, but rather to point out that there were elements of continuity and discontinuity in the communist movement in this respect, too. And the discontinuities were not necessary the same at all levels of international communism.

The foundation of the Communist International was characterised by a firm belief that capitalism could not develop, that it was a moribund system. This belief - or hope - was not shattered when capitalism didn't die immediately after the First World War and the communists found it necessary to speak of the "temporary stabilization of capitalism". The hope or belief received new fuel in the beginning of the Great Depression.

According to the Bolsheviks, and probably the other communists, too, there was a direct link between revolution and poor economic and political conditions of workers. This concept didn't break down during the Great Depression, although it didn't "produce" communist revolutions, but rightist revolutions or coups instead. In some countries, however, the actions taken by governments in order to ease the pressures of the Depression, were able to shatter this concept and lead people to think that capitalism was also able to improve the status of workers. 


\section{The acquisition of power}

Did the acceptance of the idea that capitalism was a moribund system mean that all those who became communists shared the opinions of the Bolsheviks that the only option for the workers was to revolt, seize power and repress the rights of the bourgeoisie by use of force? Or did they regard Russian revolution as a more general ideal, as a liberation from all oppression, regard to the means by which they could reach this goal? These questions are posed to sharpen our understanding of the relation between the actual views expressed by Lenin and the Communist International, and those of the various national movements.

The Bolsheviks didn't want to study the conditions under which their revolution took place, but rather they tried to enlarge its significance and make an example of it. Furthermore, with the emphasis on the party's role and importance, it became easier to forget the conditions under which it had come to power, when such affection might have reduced the authority of Bolsheviks.

It was not usual among communists to ask whether the Russian revolution was an international example. In 1919-20, however, many Left communist groups doubted whether the revolution in Western Europe could be of the same kind as in Russia. ${ }^{18}$ The same doubt was cast by some persons or groups who first joined the International but left it later. ${ }^{19}$ Antonio Gramsci was occupied with these very questions in the early 1920 s and later in prison. ${ }^{20}$

Did this mean that all the rest accepted the view that the revolution in their countries would be like the October Revolution? At least, there were no successful revolutions or coups based on the Russian example between 1919 and 1943, though there were attempts. This is not, however, to say, the communists would not have tried, had the conditions been more favourable.

The issues of power were not discussed in all national communist movements because they were not considered urgent or because any discussion of the subject was seditious. In many countries, however, the activities of the opponents had convinced the communists that it was possible to get the power only by force. 
Therefore, they might have thought of seizing power by actively creating tensions between the state apparatus and various movements. But it is also possible that the old belief, according to which the working class would come to power more or less automatically, survived, as in Finnish communism. This belief could be on the basis of the struggle at the ideological and cultural level.

Whatever their conceptions of power, the importance of the national communist movements lay in what they accomplished during their "preparatory" work. In their activities the national movements usually tried to question the values, the customs and the organizational forms of their nations and to present an alternative for them. It was very often struggle for forums, interests, symbols and identities.

It could be argued that the longer freedom of speech, assembly and association were not granted, the more precious they became as final goals. Perhaps even participation in some of the activities organised internationally from Moscow, as for example the work in the aid organisations for political prisoners, might have also contributed to the same tendency regardless what Moscow thought. $^{21}$

The unintentional influence of communist parties and organisations was probably greatest. Through their speeches they certainly gave rise to fears out of proportion to their size $e^{22}$, but that might have been their intention. Their unintentional and also paradoxical influence can be seen elsewhere. Is it, for example, that despite their principally negative attitude towards the bourgeois democracy and willingness to suppress the rights of the well-to-do, many communists defended civil rights or at least the pluralist principles of civil society during the 1920s? Perhaps they also taught initiative to various groups of people, which was not necessarily their intention. 


\section{Did the national feature of Communism disappear in Moscow?}

In the Communist International, it was customary to encourage the idea that the representatives of the International were capable of interfering in all matters no matter where they arose. That was evident in the way the International sent "advisers" to various countries $^{23}$ and later in the nominations to the secretariats in the Comintern. ${ }^{24}$

Eric Hobsbawm has spoken of the minority of genuinely international cadres, whose nationality was of merely biographical interest. ${ }^{25}$ It would be tempting to include all the functionaries in the Comintern into these "international cadres". But did the functionaries lose their past and national origins in Moscow?

Did, for example, Otto Ville Kuusinen preserve something of his Finnish past during his many years in the secretariat of the Comintern? ${ }^{26}$ That he did is not clear in the organizational theses he wrote for the Third Congress of the Comintern - Lenin who had blessed them during the Congress called them later too Rus$\operatorname{sian}^{27}$

But there was one more general feature of Kuusinen's past in the Finnish labour movement that was preserved. During his early years he had learned that the correct political position was in the center, and he used to criticise reformists in the right and anarchists in the left. From that standpoint it was easy to proceed with condemnations of the right- and left-deviations in the Comintern - even the order was usually the same. ${ }^{28}$ But in this respect, the whole Comintern was Kautskyist.

The Comintern obviously realised the importance of its location for the attitudes of the various national parties and their members. At least, the International used to invite national communists suspected of "deviant" thinking to Moscow. The central committee of the SKP tried to follow the example. ${ }^{29}$ But did the communists entirely forget their earlier thoughts in Moscow?

The example of August Thalheimer and Heinrich Brandler, the German communists, who as "rightists" had been summoned 
to Moscow to learn the correct way of thinking, proves otherwise. They didn't give up their thoughts. Thalheimer, for example, wrote an analysis of fascism that differed from that of the International during the preliminary work of the Comintern program. But Thalheimer was not, during his Moscow years, working in the central apparatus of the Communist International. ${ }^{30}$

But what about the representatives of the parties in Moscow? Did they come to Moscow to get advice or criticism, or did they come there to pursue their national ideas and national interpretations? Both of these questions refer to the fact that there was something national in these individuals. The respect they felt for the Communist International and for Soviet Russia/the Soviet Union, the fact that they were living in Moscow and naked pressure often combined to persuade these persons to accept the "international" ideas of the functionaries in the International.

\section{Different agendas}

Differences between the national communisms were evident in many respects. Not even the reception and implementation of ideas originating from the International were alike; rather the parties made choices, as demonstrated in the case of one of the political slogans in the international communist movement, that of the alliance between proletariat and peasantry. ${ }^{31}$

This concept was one of those ambiguous concepts so common in the communist terminology; it could refer to the cooperation between working class and peasants in the capitalist society for taking the power, but also to the situation after the seizure of power, in which case it was identified with the dictatorship of the proletariat. In this latter respect it was part of the bolshevisation of the doctrine in the communist movement - to talk of the dictatorship of the proletariat referred more generally to Marxist tradition - and not only to its Russian interpretation and to the supposed Russian model. 
In spite of its importance in the Comintern, this concept was not considered important everywhere. This goal was not very relevant, for example, for the communist parties in Britain and Germany, but on the other hand it was important for the parties in Italy and Finland.

The explanation is, of course, rather simple, and it has something to do with the level of industrialisation; the number of peasants compared to the proletariat was not great in Britain and in Germany, and accordingly, the alliance between the proletariat and the peasants was not regarded as important. In Italy and in Finland, where the number of peasants was much higher than that of the proletariat, this alliance was discussed quite at length. In Finland, $70 \%$ of the population got its living from the agricultural sector in 1930 .

This was, however, not the only reason. The peasant question had been an important one in the Finnish labour movement before the Civil War and the division of the labour movement. In Finland, a great number of the members and supporters of the labour movement were living in the countryside and working in the agricultural sector at least part of the year. The tenant question had been of special importance - and difficulty - in the labour movement. In Britain and in Germany, these questions did not have this degree of significance.

In this respect, there was a certain continuity, but also a rupture. In the old labour movement it had been usual to think that the proletariat included agricultural workers, crofters and even some of the smallholders. But the new slogan presented two different groups, proletariat and peasants, and wanted to demonstrate the priority of the former.

In Finnish communism, the use of these concepts was not uniform; some didn't want to accept the term peasant. They regarded it as referring to those who had participated in the Civil War on the White side and preferred the concept smallholder. That term was also frequently used in the titles of electoral organizations and parliamentary groups from 1924 onwards. Even the most important agricultural propagandist, who was living in Soviet Rus- 
sia and wrote articles for Finnish newspapers, preferred to follow the old ways of writing in spite of his pseudonym ("Peasant") and the ubiquity of that word in his articles. ${ }^{32}$

The situation in the home country also had an effect on how the advice of the International was received. In the autumn 1923, the leadership of the Communist International placed its hopes, at least for a while, in the German Revolution as a starting point of the World Revolution. Otto Ville Kuusinen was among the hopeful leadership, and, encouraged by the prospects in Germany, gave Finland instructions to make preparations for the revolution even there. These instructions included, for example, occupying the gas and electric plants.

What guided Kuusinen's thinking was, of course, the idea of the cumulative revolution. He had even earlier connected the revolution in Finland to the revolution somewhere else. He had, as a matter of fact, good grounds for that - the Revolution in Finland in 1918 was, in some respects, a result of the Russian Revolutions. Kuusinen's thoughts in the autumn 1923 might also, more generally, reflect on his inclination to be enthusiastic with regard to the revolution in other countries when there were difficulties in Finland. ${ }^{33}$

Kuusinen's ideas had no significance in Finland. They didn't even become known there, because the other members of the central committee residing at that time in Petrograd didn't send them to Finland. Perhaps they were somewhat more aware of what was happening in Finland in those days.

In Finland, Finnish communism was, a few months earlier, hit by severe blows. In August, the national and local leaders of the Socialist Workers' Party (SSTP), among them the members of the parliament, had been arrested, the activities of the party and the publication of its newspapers were forbidden. Under those circumstances, the members of Finnish communism were not taking steps to occupy gas or electric plants in order to make revolution but rather to found new organizations and newspapers to be able to participate in the municipal elections. Maybe this was their revolution under those circumstances. 


\section{Cells in factories, local districts or nowhere?}

It was also possible to accept certain principals, but their implementation was not as easy.

One of the central elements in the bolshevisation of the parties was the reorganisation of the party structures. The Third Congress of the Comintern prescribed cells, fractions and working groups as units of the party organisation. This vague description was later crystallised in an order, according to which cells in factories and other working places should be the basis of the party organisation.

The implementation of this directive met with difficulties, and it was thus repeated in many meetings of the Comintern. Especially the demand to abandon the form of organisation by districts and regions ran against the traditional western conception of the party based on local organisations, and was therefore opposed. According to E.H. Carr, this also succeeded in demonstrating the small number of factory workers in the national parties. ${ }^{34}$

Carr assumed that it was easier for underground parties to reorganise on the basis of factory cells. The example of the SKP doesn't, however, support this argument. From 1925 the SKP tried to create its underground organisation on the basis of working places, but without much success. The secret functionaries of the SKP working in Finland could not lay foundations for factory cells in many of the large working places in Helsinki, Turku and Oulu, even though most of the workers in them were communist-oriented. The result was a little better in Tampere, but in many other towns the few cells consisted of one or two men or women, and their contacts with party functionaries, or vice versa, were rather occasional.

The leaders of the SKP tried to justify the factory cells by claiming that the employers could not sack their workers because they had to keep the factories running. In a country where the connections with the SKP were criminalised and where there were not very many actual industrial working places and an oversupply of workers this was not very convincing. 
That is why many of the workers were not enthusiastic about secret party work as long as there were possibilities for public activities. Neither could they understand why there should be a secret party organisation in the factory, as there usually was a trade union organisation that took care of their interests. Not even after the summer 1930, when many of these trade union organisations were forbidden as communist, did the communist oriented workers want to organise themselves into party cells. Instead, they left party politics and worked in local trade and cooperation organisations or even in organisations of the Social Democratic Party.

In 1925, the SKP issued instructions that organisations in the factories should be the basis for public reorganisation of Finnish communism in Finland. These instructions came late, those in Finland had already reorganised themselves on a geographical basis after the Socialist Workers' Party was forbidden in August 1923. The directives of the SKP were thus not successful in this respect either.

\section{Revolutionary tribune in theory and practice}

The resolution entitled Theses on communist parties and parliament adopted in the Second Congress of the Communist International in 1920, was probably not among the most important issues for the parties in Britain or in Sweden. But in Finland, where the Socialist Workers' Party got 27 out of 200 seats in the parliament in the summer of 1922, the resolution was studied carefully. The example of Finland demonstrates that it was possible to accept the directions of the International but to interpret them differently, more according to the earlier concepts. ${ }^{35}$

According to the resolution of the International, parliament could not "serve as the form of proletarian State administration" nor, in conditions of imperialism, "as the centre of the struggle for reforms" or "for improving the lot of the working class", as in the preceding epoch. For communists, parliament was useful only as a revolutionary tribune from which they could "help the masses 
to shatter the State machine and parliament itself In the late summer of 1920, the International still, at least in this respect, lived in the euphoria of the immediate world revolution. Therefore, it wanted to see the speeches from the parliament as a spark for it. ${ }^{36}$

The Socialist Workers' Party accepted the theses in its meetings and repeated them in the directives for the parliamentary group. In practice, the group didn't, however, try to agitate for revolution from the parliamentary tribune, but presented claims for undoing the wrongs of the Civil War and its aftermath and for securing the civil rights of workers and their organisations.

These questions were very important for the Finnish workers, at least, for those who had participated in the Civil War on the Red side. However, the parliamentary group didn't use their speeches to try to agitate the workers to open the gates of the prisons immediately. They rather wanted to point out the moral bankruptcy of the bourgeois society that, according to them, didn't follow its own constitution in denying the rights of workers.

The idea to utilise parliament for purposes of agitation was not a new one. Participation in parliament was viewed, for example by Anton Pannekoek, a Dutchman who lived in Germany in the first decade of the century, from the standpoint of developing class consciousness. For Pannekoek, whose writings were known also in Finland, agitation from the parliament and the organisation of the workers thereby was a long-term process. This idea was preferred by the SSTP. It was also in accordance with the experiences of the Finnish labour movement in 1907-1918.

The parliamentary group of the SSTP did not have much influence on the discussions of the parliament. The group could, and would, not sabotage its work, as the resolution of the International had advised. This part of the resolution was a dead letter for Finnish communist oriented members of the parliament in the late 1920s, too. Not even the German communists, who got a substantial group in the German parliament in 1924, could have much influence on the work of the parliament, even though they tried to organise demonstrations in the opening of the parliament. ${ }^{37}$ 


\section{International or national calendar? ${ }^{38}$}

The repetition of certain ideas, slogans and concepts, and cultural events was of great importance in tying the members to international aspects of the communist movement, although the influence was not immediate.

To celebrate the First of May as an international occasion of the workers' movement was among the most important decisions of the Second International. In this respect, the Communist International and the Communist Youth International tried to go much further by launching several festivals, by means of which the communist movement wanted to demonstrate its strength and internationalism. On the basis of successive festivals and campaigns, it was even possible to write a communist calendar.

Among the festivals initiated by the Communist International and the Communist Youth International were, for example, the anniversaries for the three Ls in January and for the Paris Commune in March, the International Youth Day in September, and the anniversary of the Russian Revolution in November. In the late 1920s these celebrations included also Red Day on the first Sunday in August.

The timetable of Finnish communism was not, however, determined entirely by the festivals created by the international communist movement. There were earlier celebrations, some of which were international, such as the First of May and the International Women's Day, or national, as the celebration of Work in August. The Finnish communists could also find reasons for various events in their recent past or in the present. Among them were the occasions arranged at the gravesides in memory of the victims of the Civil War; the Red Orphans' Day, celebrated in July, for assisting the children who had lost their parents in the Civil War; and political prisoners' week from 1925 on in the beginning of December as a kind of demonstration against the Finnish Independence Day and from 1929 on in March at the suggestion of the Comintern. Finnish communists had, furthermore, to take a 
stand on the anniversaries of the independent Finland and on the established festivals, such as Christmas and Midsummer.

The SKP had no official standing toward Midsummer or Christmas, but Kullervo Manner, the chairman of the party, criticized the magazines published for Christmas. According to him, the articles and pictures published in them would be good for the Salvation Army or for right-wing magazines. He didn't either want to celebrate Christmas: "To talk of Christmas, Christmas trees and their candles, is not for us."

The old traditions that had become popular during the early Finnish labour movement remained very strong in Finnish communism's celebrations of Midsummer and Christmas. They were, for example, evident in the references to pagan ways of celebrating both Christmas and Midsummer as feasts of light or to celebrate Christmas in the "Christmas churches", i.e. in the workers' halls on the Christmas Day morning, with their "sermons". In this respect the feasts of Finnish communism were closer to those of the Austrian social democrats than those of Russian communists. ${ }^{39}$

But the celebrations originating from the international communist movement were not entirely international either. This is evident, for example, in the anniversaries for the three Ls, Karl Liebknecht, Rosa Luxemburg and V. I. Lenin.

In its first congress in November 1919, the Communist Youth International urged its members to organise anniversaries in the memory of Karl Liebknecht and Rosa Luxemburg, who were killed in January 1919. In Finland these anniversaries took place for the first time in $1921 .^{40}$

They had their origin in Germany, but they received a Russian flavour after the death of Lenin in 1924. Besides the Liebknecht-Luxemburg anniversaries, the Communist International and the Communist Youth International urged the importance of organizing Lenin anniversaries or Lenin weeks. The Executive Committee of the Communist International, as a matter of fact, mentioned only Liebknecht and Lenin, which indicated a wish to leave Rosa Luxemburg aside because she, according to the Bol- 
sheviks, had made a serious mistake in emphasising the spontaneity of the working class.

In Finland, these instructions were not obeyed. From 1925 onwards there were usually anniversaries for the three Ls, even though the central committee of the SKP also preferred successive Liebknecht and Lenin weeks. There was also discussion among the SKP leadership of writing an explaining article of luxemburgism, as Rosa Luxemburg's views were labelled in the Soviet Union, but nothing came of that.

The functionaries of the International thought that by means of these anniversaries it would be possible to teach something of the actuality of Lenin's ideas. As a matter of fact, they themselves restricted that possibility by writing in their directives everything they could think of. Therefore, they probably were not very useful for organising actual events, but might have been more important in shaping the ideas of the communist youth. At least, they gave an idea of Lenin's greatness and genious, as well as of Liebknecht's courage and readiness to speak against arms, and that was possibly the most relevant lesson for the communist youth in the late $1920 \mathrm{~s}$

\section{Popular culture: trash or part of own culture?}

The creation of their own festivals and of the choirs that performed in them can be seen as an attempt to prevent the influence of popular culture in the workers. The Communist International didn't articulate this standpoint, but in the leaderships of national parties there were plenty of doubts about popular culture.

In his article "The Lost World of the British Communism" Raphael Samuel writes that the communists "related uneasily to working-class culture" and were "apt to think of working-class pleasures as degrading". According to them, "Hollywood films' were rubbish, popular reading 'trash", dance halls were viewed "with suspicion". 
In Finland it is also possible, on several occasions in the 1920s and later on, to find the same kind of attitudes about the way the workers spent their leisure time. ${ }^{42}$ For some of the Finnish communists in the 1920s, restaurants with jazz bands and dancing were condemned as "nests of debauchery" and traps for workers. Also jazz music as such were condemned, and films presented in the cinema theatres were regarded as "bourgeois filth".

On the other hand, as early as the 1920s large workers' associations were able to have their own movie theatres, whose programmes didn't very much differ from those of the other movie houses. Orchestras playing popular jazz were also regular performers in the communist youth festivals of the late 1920s. On these occasions even the International could be played in a jazz arrangement ${ }^{43}$. Those participating in the communist youth movement in Finland were also in other ways active in popularizing jazz. ${ }^{44}$

The different attitudes toward popular culture could also be seen in publishing. ${ }^{45}$ The literary weekly and the pictorial magazine published by Finnish communists in the 1920s were also of international origin, but not according to Moscow's precepts. The actual model for the pictorial magazine came from Germany, but the basis for these publications was Finnish. Both of these enterprises were started for economic reasons, to raise money for the companies that were publishing daily newspapers. But as if by accident, these publications started to compete with other leisure activities, and they could be regarded as more or less conscious attempts to create some kind of counter culture.

The contribution of Itä ja Länsi (East and West), the pictorial magazine published in 1924-1930, to workers' leisure was in the presentation of fashion, film stars, various cultural events, cookery, anecdotes, cartoons, and, of course, plenty of pictures. The field of Revontulet (Northern Lights), the literary weekly, published in Oulu in 1926-1930, was a little different - it published short love, detective and other stories, but also excerpts from classical literature. 
Neither Itä ja Länsi nor Revontulet got a favourable reception at the headquarters of the central committee of the SKP in Moscow. The leaders of the SKP were, firstly, annoyed by the fact that the initiative for these enterprises came from Finland and not from the central committee. Secondly, they found "pornography" in the fashion pictures of Itä ja Länsi and criticized the "petty-bourgeois character" of Revontulet. They, however, moderated their criticism toward Itä ja Länsi after the editor promised to publish more pictures and stories about the Soviet Union.

The dispute over these magazines demonstrates how some communists wanted merely to condemn popular culture and how others wanted to offer their own alternative in this field, too. These different attitudes reflected not only national and international aspects, but also differences between the generations.

\section{"Uncle Joe" or the "steely" leader?}

Stalin, the Russian communists and the Communist International were all involved with the creation of the Stalin myth. In the Communist movement Stalin became "superhuman personification of the communist virtues", as Raphael Samuel has put it. But during the years of the Second World War alliance, British communists gave Stalin also the affectionate diminutive "Old Joe" or "Uncle Joe". ${ }^{46}$

Among Finnish communists this could have been felt as a sacrilege, for them Stalin was always a respected and honoured leader. But for most Finnish communists Stalin was not an ally in the war, at least not during the Winter War in 1939-1940. The Finnish communist culture was also born and lived under persecution, and was, therefore, inclined to be somewhat sober-sided. But obviously the solemn form of address also reflected the unspoken knowledge that thousands of Finns were killed in the purges in the Soviet Union in the late thirties. And this was enough to prevent them from addressing Stalin affectionately. ${ }^{47}$ 
These examples point out that Perry Anderson was right; the relations between national and international determinants in the Communist movement are complex. I may, however, have committed the mistake the Bolsheviks did, that is, I may have generalized on weak grounds, on the basis of one country, but if so, my mistake is not as fatal as that of the Bolsheviks.

\section{Notes}

1 Perry Anderson, 'Communist Party History', in Raphael Samuel(Ed.), People's History and Socialist Theory. (London: Routledge \& Kegan Paul, 1981), p. 150.

2 On this, see Frank Deppe, 'Proletarischer Intemationalismus und nationaler Klassenkampf. Zur Europa-Politik der Kommunistischen Parteien', in Frank Deppe (Hrsg.), Arbeiterbewegung und westeuropäische lntegration (Köln: Pahl-Rugenstein, 1976) pp. 319-336; Eric J. Hobsbawm, 'Working-Class Internationalism', in Internationalism in the Labour Movement 1830-1940. I. Edited by Frits van Holthoon and Marcus van der Linden (Leiden: E.J. Brill, 1988) pp. 6-8.

3 Anderson, op. cit., pp. 145-146; in Finland, for example, history books written by former party functionaries include Antti Hyvönen, Suomen Kommunistinen Puolue 1918-1924 (Tampere: Kansankulttuuri, 1968); Antti Hyvönen, SKP:n maanalaisuuden vuodet (Kuopio: Kansankulttuuri, 1971); for Britain see James Klugmann, History of the Communist Party of Great Britain. Volume One. Foundation and Early Years 1919-1924 (London: Lawrence and Wishart, 1968).

4 See e.g. Maurice Isserman, Which Side Were You On? The American Communist Party During the Second Word War (Middletown: Wesleyan University Press, 1985 (1982); Paolo Spriano, Stalin and the European Communists. (London: Verso, 1985); Kevin Morgan, Against Fascism and War Ruptures and continuities in British Communist politics, 1935-1941 (Manchester: Manchester University Press, 1989).

5 Geoff Eley, 'International Communism in the Hey-Day of Stalin', New Left Review, May/June 1986; David Mayfield, 'What is the significant context of Communism', Social History, 1988 pp. 351-362; see also Geoff Eley and Keith Nield, 'Why does social history ignore politics?', Social History, 1980 pp 249-271.

6 Mayfield, op. cit., pp. 352, 361. 
7 For Finland, see e.g. Leevi Norrena, Talonpoika, pohjalainen - ja punainen. Tutkimus Etelä-Pohjanmaan Järviseudun työväenliikkeestä vuoteen 1939 (Tampere: Suomen Historiallinen Seura, 1993); Elina Katainen, Akkain aherrusta aatteen hyväksi. Suomen Naisten Demokraattinen Liitto 19441990 (Tampere: Kansan Sivistystyön Liitto, 1994); Kimmo Rentola, Kenen joukoissa seisot? Suomalainen kommunismi ja sota 1937-1945 (Juva: WSOY, 1994); for the United States, e.g., Isserman; Robert Cohen, When the Old Left Was Young. Student Radicals and America's First Mass Student Movement, 1929-1941 (New York: Oxford University Press, 1993); New studies in the Politics and Culture of U.S. Communism. Edited by Michael E. Brown, Randy Martin, Frank Rosengarten, and George Snedeker (New York: Monthly Review Press, 1993); for Britain, e.g. Nina Fishman, The British Communist Party and the Trade Unions, 1933-45 (London: Scholar Press, 1994); Opening the Books. Essays on the Social and Cultural History of British Communism. Edited by Geoff Andrews, Nina Fishman and Kevin Morgan (London, Boulder: Pluto Press, 1995).

8 On Communism studies after the opening of Comintern archives, see e.g. Brigitte Studer, 'Die Rückkehr der Geschichte: Das Bild der Komintern nach Öffnung der Archive', Beiträge zur Geschichte der Arbeiterbewegung, 2/1997 pp. 15-29; Tauno Saarela, 'Kommunismitutkimuksen pauloissa', Työväentutkimus 1995 pp. 2-9.

9 See e.g. Arthur Schlesinger, jr., 'Some lessons from the Cold War', in The End of the Cold War Its Meaning and Implications. Edited Michael J. Hogan (New York, 1992), p. 55.

10 See Quentin Skinner, 'Meaning and Understanding in the History of Ideas', History and Theory 1969; Quentin Skinner, 'Motives, Intentions and the Interpretation of Texts', New Literary History 1972; Quentin Skinner, The Foundations of Modern Political Thought. Volume One: The Renaissance (Cambridge: Cambridge University Press, 1978), pp. xi-xiv; Dominick LaCapra, Rethinking Intellectual History. Texts, Contexts, Language (Ithaca: Comell University Press, 1987 (1983)), pp. 14-71; Dominick LaCapra, History \& Criticism (Ithaca: Comell University Press, 1985), pp. 127, 129. See also Kari Palonen, Tekstistä politiikkaan. Johdatus tulkintataitoon (Jyväskylä: Jyväskylän yliopisto, valtio-opin laitos, 1987), pp. 110-115.

11 See, e.g. Helmut Konrad, 'Arbeitergeschichte und Raum', in Geschichte als demokratischer Auftrag. Karl R. Stadler zum 70. Geburtstag (Wien: Europa-Verlag, 1983), pp. 69-70; Ernst Hanisch, 'Neuere Studien zur Marxismus-Rezeption in der deutschen und österreichischen Arbeiterbewegung, in Arbeiter und Arbeiterbewegung im Vergleich. Berichte zur internationalen historischen Forschung. Herausgegeben von Klaus Tenfelde. Historische Zeitschrift Sonderheft. Band 15. München 1986, pp. 585-608, 610. On the transformation in general, see Palonen 1987, pp. 85-87, 100-101; Jukka Kanerva, Kari Palonen, 'Introduction', in Transformation of Ideas on a Periphery. Edited by Jukka Kanerva, Kari Palonen (Ilmajoki: The Finnish Political Science Association, 1987), pp. 8-9. 
12 This is evident in studies of Marxism, see Stuart Macintyre, A Proletarian Science. Marxism in Britain 1917-1933 (Bristol: Cambridge University Press, 1980); Paul Buhle, Marxism in the United States. Remapping the History of the American Left. Revised Edition (New York, London: Verso, 1991).

13 Regarding the Communist International, Kevin McDermott and Jeremy Agnew, The Comintern. A History of International Communism from Lenin to Stalin (Hong Kong: Macmillan Press Ltd, 1996). Even in the earlier Internationals the strong parties had tried to tum their national strategies into international ones, see e.g. Susan Milner, The Dilemmas of Internationalism (Worcester: Berg, 1990), pp. 11-12.

14 In his classic study on German Communism, Die Wandlung des deutschen Kommunismus. Die Stalinisierung der KPD in der Weimarer Republik. Band 1-2. (Frankfurt am Main, 1969), Hermann Weber pointed out that the disengagement of the Communist party from the political issues of the Weimar Republic created preconditions for the power of the party apparatus, and contributed to party's becoming more and more the agitator on behalf of the International in Germany, ibid., pp. 8-13, 16.

15 Regarding the Germans, see Ossip K. Flechtheim, Die KPD in der Weimarer Republik (Frankfurt am Main: Europäische Verlagsanstalt, 1973 (1969)).

16 Kommunistinen Internationaali. Historiallinen katsaus (Moskova: Edistys, 1973); McDermott and Agnew; concerning the periodisation, see also Jürgen Rojahn, 'A Matter of Perspective: Some Remarks on the Periodization of the History of the Communist International', in Centre and Periphety. The History of the Comintern in the Lights of New Documents. Edited by Mikhail Narinsky and Jürgen Rojahn (Amsterdam: IISG, 1996), pp. 35-45.

17 See Mikko Majander's article in this book.

18 For a discussion of left Communist groups, see Hans Manfred Bock, Geschichte des "linken Radikalismus" in Deutschland. Ein Versuch (Frankfurt am Main: Suhrkamp, 1976), pp. 98-103; John Gerber, Anton Pannekoek and the Socialism of Workers' Self-Emancipation, 1873-1960 (Dordrecht: Kluwer Academie Publishers, 1989), pp. 144-145.

19 Similar doubts were east, for example, by some Swedes and the Norwegian labour party, see Erland F. Josephson, SKP och Komintern. Motsättningarna inom Sveriges Kommunistiska Parti och dess relationer till den Kommunistiska Internationalen (Uppsala: Historiska Institutionen vid Uppsala Universitet, 1976); Lars Björlin, 'Röd skandinavism i Komintern. SKPs kris och splittring 1924', Arbetarhistoria 1994, pp. 18-30; Per Maurseth, Gjennom kriser till makt (1920-1935). Arbeiderbevegelsens historie i Norge 3 (Oslo: Tiden Norsk Forlag, 1987), pp. 271-299; see also K.H. Tjaden, Struktur und Funktion der KPD -Opposition (KPO). Eine organisationssoziologische Untersuchung zur Rechtsopposition im deutschen Kommunismus zur Zeit der Weimarer Republik (Hannover: SOAK Verlag 1983 (1964).

20 See e.g. Walter L. Adamson, Hegemony and Revolution. A Study of Antonio Gramsci 's Political and Cultural Theory (London: University of California Press, 1983 (1980), pp. 86-90, 215-228. 
21 Concerning International Red Aid (Mezhdunarodnaja organizatsija pomoshtshi bortsam revoljutsii) (MOPR), see E.H. Carr, Socialism in one country 1924-1926. Volume three (Aylesbury: Pelican Books, 1972), pp. 985-989; on its work e.g., Wolfgang Abendroth, Ein Leben in der Arbeiterbewegung. Gespräche, aufgezeichnet und herausgegeben von B. Dietrich und J. Perels (Frankfurt am Main: Suhrkamp, 1976), pp. 91-107.

22 On this, see e.g. Eric Hobsbawm, 'History and Illusion', New Left Review 220.

23 Finns were e.g. sent to Scandinavia and America, see e.g. Erkki Salomaa, Yrjö Sirola. Sosialistinen humanisti (Kuopio: Kansankulttuuri, 1966), pp. 294-297; Alexander Kan, Nikolai Bucharin und die skandinavische Arbeiterbewegung (Mainz: Decaton, 1993; for the other advisers, see e.g. Reinhart Kössler, 'Revolution in a Foreign Land: Eyewitness Accounts by Soviet Advisers to China, 1923-1927, in Internationalism in the Labour Movement 1830-1940, op. cit., pp. 109-134.

24 Peter Huber, "The Cadre department, the OMS and the "Dimitrov" and "Manuilsky" Secretariats during the Phase of the Terror', in Centre and Periphery, op. cit., pp. 122-152.

25 Hobsbawm 1988, p. 12.

26 On this see Kimmo Rentola's article.

27 Tauno Saarela : Suomalaisen kommunismin synty 1918-1923 (Tampere: Kansan Sivistystyön Liitto, 1986), pp. 345, 348.

28 Ibid, p. 57.

29 Ibid., pp. 342-343.

30 See e.g., Jürgen Kaestner, Die politische Theorie August Thalheimers (Frankfurt/ Main: Campus Verlag, 1982), pp. 69-74, 115-122; Heikki Marjomäki, Oppositio vaiko pelkkä nolla? Kommunistische Partei (Deutschlands)-Opposition (KPO). August Thalheimer in Memoriam, Uudistuva Ihmiskunta 4/1986, pp. 1-30.

31 The examples regarding Finnish communism are based on my forthcoming book Suomalainen kommunismi vastakulttuurina, 1923-1930.

32 Cf. Tauno Saarela, 'Santeri Mäkelä vuoden 1918 jälkeen', in Talonpoikainen sosialisti. Santeri Mäkelä poliittisena toimijana ja kirjailijana. Toimittanut Tauno Saarela (Helsinki: Työväen historian ja perinteen tutkimuksen seura, 1997), pp. 54-78.

33 The same attitude is quite evident in Kuusinen's speeches during the meetings of the Red Finn refugees and in the founding congress of the SKP in August 1918, see Saarela 1996, p. 39-43, 56-58.

34 Carr, pp. 948-972.

35 Saarela 1996, pp. 275-289.

36 The Communist International 1919-1943. Documents. Selected and edited by Jane Degras. Volume I 1919-1922 (London: Oxford University Press, 1956), pp. 150-155.

37 Weber, p. 334.

38 This is mainly based on my forthcoming book mentioned above; see also Katainen, pp. 26-29; Tauno Saarela, 'Class Struggle in the Cemetery', in 
Labour Movements. Socialist History 9. Edited by Willie Thompson, David Parker, Mike Waite and David Morgan (London: Pluto Press, 1996), pp. 82-89.

39 On Christmas and Finnish communists, Tauno Saarela, 'Joululta piti riisua juhlavaipat, mutta ... Suomalaisen kommunismin joulu 1920-luvulla, Kansan Uutiset 23.12.1997; on the Austrian Social Democracy, Josef Weidenholzer, Auf dem Weg zum "Neuen Menschen". Bildungs- und Kulturarbeit der österreichischen Sozialdemokratie in der Ersten Republik (Wien: Europaverlag, 1983 (1981)), pp. 179-191; Bela Råsky, Arbeiterfesttage. Die Festund Feiernkultur der sozialdemokratischen Bewegung in der Ersten Republik Österreich 1918-1934 (Wien-Zürich Europaverlag, 1992), pp. 3, 34-35, 41; for the Bolsheviks, cf. Richard Stites, Revolutionary Dreams. Utopian Visions and Experimental Life in the Russian Revolution (New York: Oxford University Press, 1991 (1989)), pp. 109, 230-231

40 Regarding the beginning of these anniversaries, see Unter dem roten Banner Bericht über den ersten Kongress der Kommunistischen Jugendinternationale (Berlin: Junge Garde), p. 74; Die Jugend der Revolution. Drei Jahre proletarische Revolution 1918-1920 (Berlin: Verlag der Jugend-Internationale), pp. 27,30 .

41 Raphael Samuel, 'Class Politics: The Lost World of British Communism, Part Three', New Left Review 165, p. 71.

42 For more information about attitudes in the 1940s, Vesa Kurkela, Tanhuten valistukseen. Mustikkivalistus ja perinnetyö Suomen demokraattisessa nuorisoliitossa (Helsinki: Työväenmusiikki-instituutti, 1986).

43 Ludvig Kosonen, Lippulaulu. Kuvaus Suomen kommunistisen nuorisoaktiivin elämästä vuodelta 1929 (Leningrad: Kirja, 1932), p. 34.

44 Pekka Jalkanen, Alaska, Bombay ja Billy Boy. Jazzkulttuurin murros Helsingissä 1920-luvulla (Helsinki: Suomen etnomusikologinen seura, 1989), pp. 112-123.

45 See, Tauno Saarela, 'Postilla vai Nyyrikki? Suomalainen kommunismi ja lehdet 1920-luvulla', in Palstojen takaa. Toimittanut Jouko Joentausta (Helsinki: Yleinen Lehtimiesliitto, 1997), pp. 7-18.

46 Raphael Samuel, 'Staying Power: The Lost World of British Communism, Part Two', New Left Review, March-April 1986, pp. 108-109. On the Stalin myth, C. Tucker, Stalin as Revolutionary. A Study in History and Personality, 1879-1929 (New York: W.W. Norton \& Company, 1974), pp. 462-487; Robert C. Tucker, Stalin in Power The Revolution from Above, 1928-1941 (New York and London: W.W. Norton \& Company, 1992), pp. 146-171.

47 On the Finnish communists during the purges and the Winter War, see Rentola, pp. 23-75, 166-208; on adressing Stalin, Max Engman, Kaksoiskotka ja Leijona. Nikolai Valapaton muisto ja muita kirjoituksia (Helsinki: VAPK, 1992), pp. 231-233. 


\section{Finnish communism, bolshevization and stalinization}

The terms Bolshevization and Stalinization have not been used to describe the development of Finnish communism in the interwar years because they have not been considered useful. This is not to deny the influence of the Russians or the new communist doctrine on the Finnish movement, but rather to avoid the simplification and finality that such concepts indicate. Emerging at the moment of Finland's separation from the former Tsarist empire, Finnish communism was born at once in Finland and Soviet Russia and proved willing to adapt to Bolshevism. Counteracting these links, however, was an extensive movement by West European standards, and one that remained strongly committed to Finnish labour and socialist traditions, and to the problems of Finnish society.

Other factors likewise affected relations between communists in Finland and the workers' fatherland just over the border, among them, the prohibitions and repression of the Finnish state and linguistic barriers arising from speaking a language shared with no other communist party. These national characteristics meant that Finnish communism did not fit easily into the usual pattern of communist parties falling into line with the policies of the Communist International (Comintern). Indeed, approaching Finland without these preconceptions one arrives at a paradoxical conclusion: that it was only after the dissolution of the Comintern in 1943 that the notion of Stalinization can, to some degree, be applied to Finnish communism. Even then, however, and at 
the height of the Finnish movement's 'splendid isolation' during the Cold War, the transformation was always incomplete. In this, as in earlier periods, though some aspects of Finnish communist politics may justly be described as 'Stalinized', its unevenness and complexity cannot easily be reconciled with the suggestion of totality that the Stalinization concept often conveys.

\section{Finnish communism}

Finnish communism was born in Finland and Soviet Russia, and a commitment to both countries was an innate characteristic of the movement. ${ }^{1}$ The civil war fought from January to May 1918 after Finnish independence ended in defeat for the Reds. Consequently, most of the leaders and functionaries of the revolutionary government escaped to Soviet Russia. There they concluded that the Finnish revolution had failed because they had stayed within the boundaries of bourgeois democracy. In order to overcome this, the exiles founded what became known as the Communist Party of Finland (Suomen kommunistinen puolue; SKP) in Moscow in August 1918. ${ }^{2}$ The new party determined to abandon the previous working methods of the Finnish labour movement - working through parliament, the trade unions and the co-operative movement - and propagate instead armed revolution and the establishment of a resolute dictatorship of the proletariat. Due to its illegal status in Finland, the SKP was forced to work underground, and until 1944 its principal organs were located in the Soviet Union.

In Finland itself, a commitment to communism emerged in the summer of 1919 among those dissatisfied with the politics of the refounded Social Democratic Party (Suomen Sosialidemokraattinen Puolue; SDP). The SDP's condemnation of the attempt to seize power, rejection of extra-parliamentary action and willingness to co-operate with the centre parties led many to accuse its leadership of forsaking the strict line of class struggle of the pre-civil war labour movement. After a failed attempt to secure 
a majority at the SDP congress in December 1919, a number of disgruntled members consequently founded the Socialist Workers' Party of Finland (Suomen sosialistinen työväenpuolue; SSTP) in May 1920. Subsequently, the SSTP received nearly 15 per cent of the vote in the parliamentary elections of 1922, winning 27 seats out of a possible 200. Supporters of the SSTP also boasted a majority within the Finnish trade union movement (Suomen ammattijärjestö; SAJ), including most of the important unions. But although the SSTP was concentrated in the traditional fields of the Finnish labour movement, its activity was soon made illegal; in August 1923, the party's central and local leadership, as well as its members of parliament, were imprisoned. From this point, the SSTP effectively ceased to function.

The proscription of SSTP - which was consolidated by the courts in 1924-25 - gave rise to discussions on the founding of a new party. Ultimately, however, Finnish communism in the 1920s was given expression through various local workers' associations which tried to keep up national and regional co-operation on the basis of socialist workers' and smallholders' electoral organizations (Sosialistisen työväen ja pienviljelijäin vaalijärjestö; STPV). In the period 1924-29, this loose organization gained between 10 and 13 per cent of the vote and between 18 and 23 seats in parliament before all public activities of Finnish communism were outlawed in the summer of 1930. With its representatives in parliament and on municipal councils now excluded, it was only from the autumn of 1944 that supporters of Finnish communism could again participate fully in the country's political life.

Though the establishment of two distinct branches of Finnish communism demonstrated different ideas with regard to the character and tasks of the revolutionary labour movement, the representatives of the SKP made contact with their Finnish comrades in the summer of 1919 and they worked together closely from the autumn of 1920. Some of the leaders of the SSTP and STPV belonged to the Finnish Bureau, the main body of the SKP in Finland, and some of the Finnish activists participated in the conferences of the SKP held in the Soviet Union. The SKP also 
provided financial support for the SSTP's and STPV's election campaigns and some of their newspapers. Despite these interconnections, the differing conditions in which the two branches of Finnish communism existed had a clear impact on their political line. Those in Soviet Russia were captured by the idea of the world revolution and found their salvation in Bolshevik ideas. In Soviet Russia, where communists were in power, it was easier to follow the instructions of the Bolsheviks and the Comintern than in Finland, where the movement sought to overcome the losses of the civil war while fighting for its very existence. As such, the decision of the SSTP to accept the Comintern's '21 conditions' of admission in the winter of 1921 should be regarded as an expression of solidarity with the Russian Revolution - an attempt to find shelter and support - rather than as a conscious endorsement of the centralized organizational structure instigated by the Bolsheviks.

\section{Isolation and commitment}

Despite a notable electoral presence - combined, the SSTP and SDP boasted 40 per cent of the vote and a parliamentary contingent numbering between 78 and 82 - the influence of the labour movement on political and social questions in Finland was far weaker after the civil war than before. The bourgeois parties proved unwilling to compromise in their attempt to create a united national state, resorting to administrative measures and repression to eradicate opposing lines of thought. This applied especially to those who advocated revolution and had contacts with an emergent communist movement that was regarded with suspicion; social democrats, by contrast, functioned largely without interference. For the Finnish bourgeoisie, the civil war had been fought for freedom against the Russians and their Finnish supporters; communism was thus continuously linked with the Soviet Union and a possible Soviet invasion of Finland. As such, its 
impact on Finnish society - as an image of the enemy was greater than the size of the communist movement might have suggested ${ }^{3}$

Likewise, Finnish communists proved unwilling to co-operate with other political forces. Such an attitude had a strong basis in the history of the Finnish labour movement and the commitment of pre-war social democracy to unwavering class struggle and the refusal to cooperate with other parties. Though individuals in the labour movement had from 1909 onwards advocated joint action with bourgeois parties to defend Finnish autonomy, the more militant conception of class conflict had been strengthened by electoral success. Between 1907 and 1916, the social democratic vote in parliamentary elections rose from 37 to 47 per cent, with the party gaining a majority in the parliament of 1916. Though the social democratic and bourgeois parties formed a coalition government after the 1917 February Revolution, each wished to exercise power alone, as the descent into civil war in the winter of 1917-18 made clear. ${ }^{4}$

Significantly, the SSTP and the SDP drew contrasting conclusions from the civil war. While social democrats held that the mere existence of Finnish communism strengthened bourgeois co-operation and the resort to force, members of the SSTP accused them of being content to work within the inadequate structures of bourgeois democracy. Simultaneously, the struggle to control and direct common labour organizations sustained the antagonism between members of Finnish communism and social democrats. Above all, the social democrats' demand that their greater strength in parliament should be replicated within the trade union movement aroused fierce opposition, as did their constant threat to form separate trade union organizations. Verbal hostilities were the rule, co-operation the exception. ${ }^{5}$

Isolation from other political forces, on the other hand, did not indicate isolation from Finnish society. The birth of Finnish communism was connected to large questions regarding the interpretation of the civil war and the character of the new nation state. These issues were closely related to questions of civil rights and liberties, and to the position of working people in the country. 
Though Finnish communism was, in a sense, connected to the losing side in the war, it retained a significant support base, as indicated by its successes in parliamentary elections and within the trade union movement. Moreover, members in Finland also became committed to the existing organs of government and, in fighting for their existence, their representation in parliament acquired an importance perhaps greater than in countries where communist parliamentary activities were not impeded.

\section{Marxism and marxism-leninism}

Finland had been a part of the Russian empire until December 1917. However, while the Finnish labour movement understood that the country's fate depended on the ability of the Russian revolutionaries to overthrow Tsarism, it had not regarded them as ideological or practical exemplars, but relied instead on the teachings of German Marxists. ${ }^{6}$ Following defeat in the civil war, however, the SKP's founders were undoubtedly captivated by the new communist doctrine and tried to disseminate it in Finland. Following the decisions of the Comintern, the SKP also passed on instructions on the character and political line of a communist organization. The banning of the SSTP and the Bolshevization process initiated by the Comintern's fifth world congress in 1924 strengthened these objectives. Though it was not safe to organize special campaigns for Bolshevization in Finland, the concept soon became familiar via various newspaper articles.

According to the fifth world congress, Bolshevization was supposed to indicate 'the final victory of Marxism-Leninism (or in other words Marxism in the period of imperialism and the epoch of the proletarian revolution) over the "Marxism" of the Second International and the syndicalist remnants. ${ }^{7}$ Difficulties in publishing communist books hindered the dissemination of this new interpretation of Marxism. Nevertheless, its basic ideas were introduced via some of Lenin's writings, published in Finnish in the early 1920s, and by Stalin's Problems of Leninism, published 
in Finland in 1926. Writings commemorating the anniversaries of Lenin, Liebknecht and Luxemburg also familiarized Finnish readers with them. Even so, the priority given to communist doctrine did not entirely overshadow earlier forms of Marxism, and Karl Kautsky's and Aleksander Bogdanov's books were being used in youth study groups even in the late 1920s. Furthermore, earlier Marxist interpretations - for example, a determinist reading of history - survived in Finland. No attempt was made to ponder whether the movement itself was 'burdened' with the remnants of social democratic ideology as indicated by the fifth congress. As the SDP had participated in the revolution - not 'betrayed' it as in Germany - there was not the same intense need to condemn it as in many other countries. ${ }^{8}$

Though Finnish communism was not a profoundly theoretical movement, there were areas where the influence of the new communist ideas occurred almost automatically. From the outset, the Bolsheviks had a monopoly in defining the international situation' and the 'general tasks' demanded by it. It was, for example, on their initiative that the Comintern declared the world to be living through a period of revolutions. Chastened at having confined their struggle within the boundaries of the Finnish state, the SKP's founders readily accepted the ideas of the Bolsheviks. Nor did communists based in Finland voice doubts regarding such an assessment. Although they did not share the Comintern's belief in the immediacy of revolution, they were willing to accept later Comintern assessments informed by Soviet interests. The negative, even hostile, attitude to communism of the bourgeoisie and Finnish authorities nourished the commitment of Finnish communists to the defence of the Soviet Union.

Nevertheless, with regard to Comintern instructions on daily political activity, members of the SSTP and the STPV tended to interpret policy through the traditions of the Finnish labour movement. Instructions from the east did not necessarily relate to the immediate political situation in Finland, and were not always regarded as safe or reasonable. In any case, it was not always possible to publish resolutions and instructions from the Comint- 
ern. Such efforts, as with the attempt to publish the manifesto and resolutions of the Comintern's second world congress, often led to confiscation by the police. Thus, decisions became known mainly through Finnish versions published in Soviet Russia, or from manuscript texts and other publications circulated by the underground organization of the SKP.

This, in turn, led to differing interpretations of theory and practice. The Comintern and the SKP had a tendency to overlook the practical difficulties faced by the movement in Finland and regarded the constant persecution of 'communist' organizations and members as a sign of the regime's weakness and imminent collapse. In response, they urged the movement in Finland to launch a vehement challenge to the existing system. Those in Finland, by contrast, were more content with attempts to improve the legal and economic position of the workers.

Due to these divergent circumstances, Finnish communism was not very Bolshevized in terms of discipline. While the SKP leadership kept repeating that the movement in Finland should follow its instructions, there were numerous occasions where such obedience was not forthcoming. In the autumn of 1923, with the SKP and the Comintern overwhelmed by the expectation of a German October, instructions were issued indicating the imminence of revolution in Finland. Despite this, communists in Finland continued to concentrate on the creation of their own organizations and newspapers. Similarly, in the winter of 1924, communists in Finland failed to follow the SKP's instruction to base their election campaign on the condemnation of social democrats as 'traitors of the working class', preferring instead to focus on civil rights. Nor were they inspired, in the presidential elections of the winter of 1924-25, by the slogan of a 'workers' and peasants' government' and Kuusinen's nomination as their presidential candidate. Instead, priority was again given to civil rights, and a political prisoner was selected as candidate. As late as the summer of 1928, members of Finnish communism chose to ignore the SKP's repudiation of their standing on joint lists during the municipal elections. ${ }^{9}$ 
The discrepancy between theory and practice was clear. The united front was supposed to be an offensive tactic through which communists propagated demands relating to the workers' daily interests. In Finland, however, it became a defensive action geared towards safeguarding the participation of the SSTP and the STPV in the elections of 1922 and 1924. Other expressions of the united front were rare. Neither the SSTP nor the STPV favoured the sorts of manoeuvre proposed by the SKP, exposing social democrats as the workers' enemies on account of their rejection of united front proposals. This certainly was the case in the northern parts of the country, where the movement was strong and the social democrats enjoyed only limited support. The same was also true of the youth movement, ${ }^{10}$ while the SAJ's leadership was similarly unwilling to follow every instruction coming from the SKP.

It was not always necessary to say no to the Comintern's instructions; often there were none. The initiatives of the mid1920 s, especially those regarding social and welfare legislation, were formulated by the parliamentary group on the basis of SDP policy prior to the civil war. The SKP leadership did not have anything to say about this, but its impact could be felt in the parliamentary group's initial willingness to accept sickness insurance legislation proposed by the social democrats in 1927 before voting against it in 1929. However, if this change of line reflected the Comintern's adoption of 'third period' politics, it was also due to the stronger influence of rural areas in the parliamentary group for smallholders were not covered by the legislation. ${ }^{11}$

The cultural activities of Finnish communism were also initiated mainly by the movement in Finland. Though their magazine, Itä ja Länsi (1923-30), published pictures and short news items about the economic and cultural achievements of the Soviet Union, it was not strongly committed to propagating the new communist message. The literary magazines Liekki (1923-30) and Revontulet (1926-30) were full of short stories, which, with their gloomy depictions of oppressed workers and moralizing about society's injustices, tended to follow in the tradition of the Finn- 
ish labour movement rather than the new communist ideas of the positive revolutionary hero. ${ }^{12}$ Similarly, the main aspirations of the performance groups, which became very popular among young communists in Finland from 1927 onwards, drew on Finnish working-class traditions. They did share aspects with the propaganda troupes of other European communist youth organizations, as well as Blue Blouses in the Soviet Union. With their uniforms - shirts adorned with the red star and hammer and sickle - and derisive songs, they also challenged the authorities and other political groups in a way that anticipated the combative spirit of the Comintern's third period. Even so, besides supplying meagre information on other groups, neither the Communist Youth International nor the Communist Youth League of Finland (Suomen kommunistinen nuorisoliitto; SKNL) had much to do with the emergence and work of these groups. ${ }^{13}$

\section{Organizational bolshevization}

A characteristic of the Comintern's Bolshevization campaign was to insist that communist parties shift their organizational basis from residential areas to the workplace. This demand was based on Russian experience, whereas in Finland, as in most of Western Europe, local organization had hitherto followed the demarcations of electoral districts. The same practice was at first maintained by the SSTP, but when it was outlawed the possibility of a new organizational model emerged. Communists in Finland, however, did not believe in forming organizational bases within the workplace. After a campaign was launched in autumn 1926 to found so-called electoral associations within large urban workplaces, some 30 to 40 of these were formed, but most were soon disbanded.

Certainly, the SKP wanted to build its underground organization in the workplace. Early in 1925, it set itself the target of raising the number of factory cells from 70 to 500 and, in the summer of that year, proposed founding a party cell in every Finnish 
workplace. These grandiose ambitions were not achieved, however; the number of factory cells peaked at 389 in September 1926, fell to 232 in December 1926, and continued to decline thereafter. Even the figure of 389 represented only a small percentage of the 4,000 or so industrial plants in Finland, and in any case depended on dubious statistical liberties such as the claiming of a cell where just one or two SKP members were working in a particular workplace. There were, moreover, few reports of communist activity or even propaganda within the factories, and cell members preferred to work in the legal organizations. ${ }^{14}$

In terms of inner-party relations, the prohibition of the SKP and persecution of communists in Finland strengthened the position of the apparatus at the expense of party democracy. Party congresses and other meetings were held in Soviet Russia and, with the possible exception of the 1921 congress, dominated by functionaries living there. It is therefore difficult to regard them as democratic, and party representatives were nominated rather than elected. By contrast, legal organizations in Finland followed traditional democratic procedures, albeit hindered by the attentions of the state authorities.

Financially, the SKP was at first a rather affluent party because it did not hesitate to appropriate the money and property brought by the Red government to Soviet Russia. ${ }^{15}$ However, the SKP also had heavy expenses and assisted thousands of 'red refugees' in Russia and their families in Finland. As such, the money was soon spent and already, in 1920, the SKP started to receive subsidies from the Russian party and Comintern. From 1926, the SKP was financed solely by the International, and such support proved essential for its survival.

Comintern financial assistance was also important in Finland, where legal organizations were debarred from normal fund-raising activities such as organizing collections, lotteries or the sale of insignia. Though the SSTP received a considerable sum from Finnish labour organizations in the US in 1920, its election campaigns would have been more modest but for Comintern subsidies and some of its activities would not have taken place. 
Discrepancies still existed. As the SKP leadership was central to the allocation of the money, most of it was used to strengthen the party's underground organization and the use of the subsidy was not considered properly from the point of view of the whole movement.

Though communists in Finland did not dutifully follow the instructions of the SKP, the Comintern did not often interfere in their affairs; it settled disputes in the central committee of the SKP but issued wider instructions on the party's tasks in Finland only after the SSTP was banned in the autumn of $1923 .{ }^{16}$ Even the instructions to the SAJ conference in spring 1926 were mainly formulated by the SKP leadership. It was, however, more usual for the SKP to develop its own interpretation of the more general instructions produced by the Comintern. In this respect, Finland differed fundamentally from countries like Germany and Britain, which were central to the Comintern's wider political perspective and often discussed in the organs of the International. It also differed from parties in the Scandinavian countries that received regular and detailed Comintern instructions.

This relatively limited interference suggests that Finland was not deemed a particularly important country within the Comintern. Yet it also reveals that the Comintern trusted the SKP to take care of the movement in Finland, often guided by discussions with representatives of the Russian party. Even so, there was never a foreign Comintern representative based in Finland, and this enabled the SKP to control communications between Finland and the Comintern. Furthermore, the character of information coming out of Finland was affected by the restrictions imposed on communist activity and publications. In any case, Finnish communism was not a movement much given to political discussion. Doubts regarding the politics of the Comintern or SKP were seldom articulated; rather, instructions were not strictly followed or interpreted in relation to Finnish traditions.

Despite this, the Comintern appeared relatively satisfied with this state of affairs until the spring of 1928, when the Polish-Baltic national secretariat strongly criticized the platform adopted by 
the Finns for the municipal elections of December. This criticism, alongside similar concerns regarding trade union policy, led to the 'Finnish question' coming up regularly on the agendas of the Comintern's political secretariat in 1929.

The trade union issue had its background in the Russian trade union movement's attempt to avoid isolation following the dissolution of the Anglo-Russian trade union agreement in 1927. As a result, the Russians started to advocate co-operation between the Russian and Nordic trade unions. This idea was supported by the Norwegians and Finns, who regarded co-operation as a step towards a united international trade union movement. Despite the misgivings of the 'Amsterdam' international, or International Federation of Trade Unions, an agreement on mutual co-operation and assistance was accepted by Norwegian, Russian and Finnish trade unions representatives in Copenhagen in February 1928. ${ }^{17}$ Yet, the agreement was not subsequently ratified by the Norwegian and Finnish unions, and trade union leaders in Finland feared for the unity and even the survival of the SAJ given the social democrats' threat to withdraw should the agreement be endorsed. Even the leaders of the SKP hesitated and, before falling into line, tried to get the Russians to revise the agreement. Ultimately, although the majority of local trade union associations supported the agreement, fear of division and losing contact with the Scandinavian trade union movement meant that the agreement was not ratified by the SAJ leadership. As a result, the Comintern and SKP condemned those opposing the ratification as 'opportunists', and the Copenhagen agreement proved an important factor in the dissolution of the SAJ and Finnish communism. ${ }^{18}$

All of this took place at a time of deepening economic crisis and as the right-wing parties stepped up their efforts to exclude Finnish communism from even the slightest role in the Finnish political system. According to Comintern theory, such developments were proof of the last phase of a dying capitalism and reason for the communist movement to move onto the offensive. The communist response in Finland was muted, however. On Inter- 
national Red Day in August 1929, on the anniversary of the October Revolution, and on May Day in 1930, some party members did take to the streets in defiance of the authorities. ${ }^{19}$ It is true that demands to brand the social democrats and 'opportunists' within the communist movement contributed to the isolation of Finnish communism and the eventual banning of all communist activity in Finland in June 1930. This would, however, have happened even without the unhappy interference of the Comintern.

\section{'Stalinized' isolation?}

The outlawing of all communist activity in Finland prompted the Comintern to place the SKP under strict control, meaning that most of the subsequent questions concerning Finnish communism were decided in Moscow. ${ }^{20}$ Communists in Finland were criticized by the International for being tied to legal forms of action and the movement was directed underground. Although the membership of the SKP passed 2,000 for the first time in 1932, it had no great appeal and only a small minority of members of the STPV joined its ranks. Its underground organization was also weakened by numerous arrests in 1930-33. Its significance in the early 1930s lay more in the fact that it kept alive the idea of a communist party.

The move to underground organization was also expressed in the SKP's formation of a 'red' trade union movement in the summer of 1931. While this was in line with Comintern policy during the third period, it also reflected workers' unwillingness to join Suomen ammattiliittojen keskusjärjestö (SAK), the new trade union movement founded by social democrats in October 1930. Yet the SKP initiative failed to attract members from beyond its own ranks or to provide contact between the party and the wider working masses. Other policies adopted from Comintern resolutions also failed to find support. Given that the Comintern believed the time was ripe for socialist revolution, a workers' and peasants' government was presented as an immediate goal. 
According to the Comintern, economic struggles in the depression developed quickly into political ones, and the communist party's task was to hasten this development to promote rebellion and civil war. To this end, the SKP and the Comintern began to emphasize economic questions and push political issues and civil rights into the background. This betrayed the inability of the Comintern to differentiate between bourgeois democracy and fascism; and while the SKP was criticized for its incapacity to fight and understand the significance of fascism, the Comintern itself failed to pay due attention to the increase in right-wing extra-parliamentary activity in Finland in the latter half of 1929. Instead, it focused on branding social democrats and 'opportunists' within the ranks of Finnish communism. Although the Comintern accused the SKP of confusing the white regime of Finland with fascism, it too labelled Finland as a 'fascist dictatorship' from the summer of 1930 to 1934 .

It was only in 1933 that the SKP began to change its orientation. The strikes that broke out that spring convinced the SKP that it was necessary to enter the social democratic trade unions and, in August 1933, the party instructed members and supporters to join and form an opposition within the reformist organizations. In July 1934, the party decided to give up the 'red' trade unions entirely. The change of line, however, took some time, as many old members of the SAJ were reluctant to join the social democratic trade unions, while the social democrats were unwilling to allow them in. This reorientation was closely linked to a change in the assessment of social democrats. Up to the summer of 1933, these were denounced as supporters of fascist dictatorship, and it was only in October 1934 that the SKP was ready to speak of co-operation.

Did this period indicate the 'Stalinization' of Finnish communism? The policies and activities of the SKP undoubtedly followed the instructions of the Comintern, both into isolation and out of it. The leaders of the SKP also committed themselves to self-criticisms concentrating on the ideological weaknesses of the Finnish labour movement in 1917-18 and the absence of a 
Bolshevik Party in 1918. The debate was guided by the myopic outlook of the Comintern and the Russian party leadership; the past was studied only on the basis of the shortcomings of the revolutionary party, while all estimation of circumstance, context and political power relationships was buried beneath theoretical assumptions. To mention 'objective grounds' was to attempt to hide mistakes, declared Kullervo Manner (the chairman of the SKP) in 1932.

Simultaneously, the establishment of Finnish courses within the International Lenin School (ILS) in the autumn of 1930 was used to disseminate Russian ideas and methods to the cadres of the SKP. These nine-month courses continued until 1938, and about 140 individuals took part in them. In the short run, however, the impact of the ILS students on Finnish communism was small, and most of those who were sent into underground work in Finland were subsequently arrested and imprisoned. ${ }^{21}$

But although the Comintern and the SKP expected communists in Finland to follow their instructions, this did not take place. Rather, the SKP became isolated from former supporters of Finnish communism, most of whom followed their own course. After the ban on legal organization, it was difficult for those who had supported Finnish communism to participate in political activity. Besides political suppression, the hard economic conditions, unemployment and disappearance of various forums - the closing of 'communist' labour halls, for instance - made any such activity difficult. Some joined the social democrats, but bitterness about their behaviour remained so strong that withdrawal from politics was often considered a better option. After all, indignation towards social democrats was the main reason why the great majority of former SAJ members had remained outside the SAK.

In northern Finland, erstwhile members of the STPV did get involved in the depression movements formed in the countryside, continuing the tradition of organizing around a particularly important issue, such as crop failure. Finnish communism was not an important actor in the so-called 'hack rebellion' which, in the summer of 1932, broke out in Nivala, in Northern Ostro- 
bothnia, when peasants clashed with the police. Its influence was larger, however, in the movement in Muhos, a commune 40 kilometres east of Oulu. This gave communists in northern Finland the opportunity to participate in elections and produce a peasant newspaper. ${ }^{22}$ Elsewhere, supporters of Finnish communism became voters for the SDP against the the instructions of the SKP. ${ }^{23}$

Accordingly, it was the improvement in political and economic conditions - rather than orders from the SKP - that prompted members of the STPV to join the SAK from the mid-1930s. Equally, it may be argued that it was a group of social democratic intellectuals that led supporters of Finnish communism, and even the SKP, out of isolation. This group started to talk about workers' co-operation and the defence of civil rights in 1933-34, receiving far more publicity than the SKP. This message, along with their ability to see the differences between fascism and bourgeois democracy, won them followers within the ranks of Finnish communism - particularly after the trial of Toivo Antikainen, a member of the SKP central committee, and the change of line adopted at the Comintern's seventh world congress in the summer of 1935. ${ }^{24}$ Raoul Palmgren, who was one of this intellectual group, formulated a project that focused primarily on the ideas and values of Finnish society, challenging dominant interpretations of Finnish history and the supposed continuity between the bourgeoisie of the nineteenth century and that of the 1930s. Where the former had stood for political rights and liberties, Palmgren argued, the latter suppressed them. For Palmgren, the working class embodied the best traditions of the progressive bourgeoisie. ${ }^{25}$ Such an approach was based on the Marxism of German leftists in the Second International. However, it also tallied with the traditions of the Finnish labour movement, and even with the ideas of Finnish communism which, from the beginning, had challenged the ideological institutions of bourgeois society.

There are other occasions when communists in Finland did not simply follow Soviet initiatives. This was evident after the Soviet invasion of Finland in November 1939, when many of them condemned the Soviet action and defended their home country even 
at the front. Nor did they welcome the formation of a Finnish people's government under the leadership of Otto Ville Kuusinen, who under Soviet protection returned from Moscow to Terijoki. Even Arvo Tuominen, the general secretary of the SKP, criticized the government from Stockholm. ${ }^{26}$

\section{A new beginning}

These two traditions were preserved once Finnish communism secured legal status following the truce between Finland and the Soviet Union in September 1944. ${ }^{27}$ On the one hand, the SKP emerged from the underground. On the other, the People's Democratic League of Finland (Suomen kansan demokraattinen litto; SKDL) was a new organization to the left of the SPD formed in October by communists, socialists and left social democrats. According to the communists, the SKDL was an umbrella organization; according to the socialists, it was a party.

The underground years had consolidated the secretive methods and preoccupation with orthodoxy of the SKP. They had also had a profound impact on the new leadership, which comprised functionaries who had attended the ILS and afterwards were imprisoned in Finland. There they had gradually taken a leading position and, on their release in 1944, took the initiative in organizing the newly legalized SKP. Contrary to the wishes of those who had re-established it, however, the SKP did not remain a 'cadre party', but with over 40,000 members by 1947 had to accept the idea of a mass party. On the other hand, there were many within the SKDL already well versed in demanding democratic measures in the labour movement and challenging the regime through open campaigning. The ideas put forward by Palmgren were of central importance in the formulation of the SKDL's ideological and political platform after 1944.

In November 1944, one SKDL representative entered the government on the advice of Andrei Zhdanov, the leader of the Allied Control Commission in Helsinki. On achieving 23.5 per cent 
of the vote in the March 1945 elections, the SKDL then provided the main force in a coalition government with the SDP and the Agrarian Party, both of which had been in government during the war years and accepted the 'alliance' with the Nazi Germany. These three parties issued a declaration that promised a new orientation in foreign politics, the eradication of fascism, the democratization of the bureaucracy, and the public ownership of finance capital.

The SKDL was happy working in government and through parliament, gaining positions in the state apparatus and dampening worker expectations in order to fulfil reparations to the Soviet Union. It was only in the spring of 1946 that the SKDL started to organize large demonstrations to further the realization of the government's programme. Following Soviet advice, it ceased demanding the abolition of the security police, and was eager to obtain positions for communists within its apparatus as it began to see its importance in any seizure of power. In the winter of 1948, vague discussions appear to have taken place as to whether communists should use the security policy to stage a coup; but these came to nothing, as rival parties took advantage of the situation to spread rumours of a possible communist takeover.

Following the parliamentary elections of 1948, the SKDL was ejected from government and returned to isolation. The ensuing period from from 1949 to the mid-1950s marked the high point of ideological and organizational orthodoxy in the SKP and SKDL, with the SKP's establishment of its cadre section, the purging of party dissidents and the introduction of the communist history concept derived from Stalin's letter in the early 1930s. Arguably, it was in line with the party's history to return to orthodoxy in difficult situations and try to solve political contradictions by means of organizational solutions.

Although the Winter War of 1939-40 showed that the interests of the Soviet Union and a small state like Finland were not necessarily identical, the representatives of Finnish communism did not try to emphasize the special interests of small states even after 1944. Rather, they regarded the USSR's victory in the war 
against Finland as guaranteeing Finnish communists the opportunity to work publicly. Not even the great number of Finns killed in Stalin's purges, especially in Soviet Karelia, seemed to disturb this assessment of the Soviet Union. ${ }^{28}$ Thus, Finnish communists actively propagated the establishment of a Treaty on Friendship, Co-operation and Mutual Assistance with the Soviet Union and, after Zhdanov's declaration of the two camps in 1947, committed themselves to the camp led by the Soviet Union.

\section{Conclusion}

Partly because of its size, and partly because of its strong commitment to the problems of the new Finnish nation state and the traditions of the Finnish labour movement, Finnish communism had not been a favourable object for Bolshevization or Stalinization in the interwar period. Although the SKP leadership in Russia did its best to promote such an object, the co-existence of Finnish and Soviet branches of Finnish communism combined with the difficult conditions in which communists had to operate impeded such a process. It was, consequently, only after the Second World War, with the SKP's establishment on a legal basis, that the procedures of a Stalinist party were properly introduced in Finland. Though the whole movement was strongly committed to the Soviet Union ideologically, its political solutions throughout the Comintern period and after it had their basis in the traditions of the Finnish labour movement and political discussions inside Finland. 


\section{Notes}

1 In Finland, the movement to the left of social democracy was at all times more extensive than just the communist party. Therefore, the term 'Finnish communism' is used to describe the movement as a whole, and the word 'communists', especially the expression 'communists in Finland', to refer to a larger group of persons than simply members of the communist party. On the beginning and character of the movement, see T. Saarela, Suomalaisen kommunismin synty 1918-23 (Tampere: KSL, 1996), pp. 26-64, 102-9, 12092; and idem, 'Kommunistinen internationaali ja suomalainen kommunismi 1919-35', in T. N. Lebedeva, K. Rentola and T. Saarela, 'Kallis toveri Stalin!' Komintern ja Suomi (Helsinki: Edita, 2002), pp. 9-62. In English, see J. H. Hodgson, Communism in Finland: A History and Interpretation (Princeton, NJ: Princeton University Press, 1967); A. F. Upton, The Communist Parties of Scandinavia and Finland (London: Weidenfeld \& Nicolson, 1973). On the SKP leadership in the Soviet Union, see J. Paastela, Finnish Communism under Soviet Totalitarianism: Oppositions within the Finnish Communist Party in Soviet Russia, 1918-35 (Helsinki: Kikimora Publications, 2003).

2 The SKP was originally known as the Finnish Communist Party, before becoming the Communist Party of Finland in 1920.

3 For example, R. Alapuro, State and Revolution in Finland (Berkeley, CA: University of California Press, 1988), pp. 198-214; J. Mäkelä, 'Valtakunta vai kansakunta - repressio vai integraatio? Itsenäistyneen Suomen kontrollipolitiikasta, in T. Soikkanen (ed.), Turun koulu. Juhani Paasivirran 70-vuotisjuhlakirja (Turku: Turun yliopisto, 1989), pp. 233-53.

4 See, for example, H. Soikkanen, Kohti kansanvaltaa I. 1899-1937. Suomen Sosialidemokraattinen Puolue 75 vuotta (Vaasa: SDP, 1975), pp. 120-308.

5 P. Kettunen, Poliittinen liike ja sosiaalinen kollektiivisuus. Tutkimus sosialidemokratiasta ja ammattiyhdistysliikkeestä Suomessa 1918-30 (Jyväskylä: SHS, 1986), pp. 94-102, 355-80, 424-55; Saarela, 'Kommunistinen internationaali', pp. 26-9.

6 J. Heikkilä, Kansallista luokkapolitiikkaa. Sosialidemokraatit ja Suomen autonomian puolustus 1905-17 (SHS: Tampere 1993), pp. 48-68, 128-31, 227-41.

7 J. Degras (ed.), The Communist International: Documents, Volume II, 192328 (London: Frank Cass, 1971), pp. 122-3.

8 Saarela, Suomalaisen kommunismin synty 1918-23, pp. 199-200; Saarela, 'Kommunistinen internationaali', pp. 19-21, 30.

9 Saarela, 'Kommunistinen internationaali', p. 29. Sometimes these were joint lists with social democrats; sometimes, general labour lists.

10 Saarela, Suomalaisen kommunismin synty 1918-23, pp. 295-307.

11 P. Kettunen, 'The Nordic Welfare State in Finland', Scandinavian Journal of History, 3 (2001), 235-6. 
12 T. Saarela, 'Oppressed Worker or Communist Hero? Characters in Finnish Communist Magazines of the 1920s', Socialist History, 21 (2002), 11-23.

13 T. Saarela, Luokkataistelua lauluilla, in K. Lindgren (ed.), Ajankohta (Helsinki: Poliittinen historia. Helsingin ja Turun yliopistot, 2003), pp. 120-39.

14 On these attempts, see Saarela, 'Kommunistinen internationaali', pp. 24-5.

15 On the money question, see T. Saarela, Tuhatmarkkasia, miljoonia ruplia, dollareita - SKP:n tilinpäätös 1920-luvulta', in J. Selovuori (ed.), ... vaikka voissa paistais? Venäjän rooli Suomessa. (Porvoo: WSOY, 1998), pp. 276-95.

16 Saarela, 'Kommunistinen internationaali', pp. 38-41.

17 T. Saarela, 'Den finska, skandinaviska och nordiska kommunismen på 1920talet', in P. Kettunen (ed.), Lokalt och internationellt. Dimensioner i den nordiska arbetarrörelsen och arbetarkulturen. (Sällskapet för forskning i arbetarhistoria i Finland, Saarijärvi 2002), pp. 110-12.

18 In spring 1929, the social democrats left the SAJ and started to set up their own trade unions. In Finnish communism, two groups began to take shape in the autumn of 1929.

19 N. Parkkari, Nuoret taistelun tiellä. Suomen vallankumouksellinen nuorisoliike 1900-44 (Kuopio: Kansankulttuuri, 1970), pp. 195-8,220-1.

20 For this period, see Saarela, 'Kommunistinen internationaali', pp. 45-54.

21 J. Krekola, 'The Finnish Sector at the International Lenin School', in K. Morgan, G. Cohen and A. Flinn (eds.), Agents of the Revolution: New Biographical Approaches to the History of International Communism in the Age of Lenin and Stalin (Oxford: Peter Lang, 2004), pp. 289-308.

22 M. Lackman, Taistelu talonpojasta. Suomen Kommunistisen Puolueen suhde talonpoikaiskysymykseen ja talonpoikaisliikkeisiin 1918-39 (Oulu: Pohjoinen, 1985), pp. 211-74.

23 K. Virtanen, Vaihtoehtojen niukkuus. Kommunistisen liikkeen kannattajien äänestyskäyttäytyminen Suomen eduskuntavaaleissa 1930-luvulla (Turku: Turun yliopisto, 1980), pp. 24-7,36-45.

24 Saarela, 'Kommunistinen internationaali', pp. 50-2.

25 I. Liikanen and P. Manninen, 'Realisti vai utopisti? Raoul Palmgrenin kirjallisen tuotannon maailmankatsomuksellisista ja poliittisista linjoista, in I. Liikanen and K. Sallamaa (eds.), Palmgrenin työ (Oulu: Oulun yliopisto, 1982), pp. 8-13.

26 K. Rentola, 'The Finnish Communists and the Winter War', Journal of Contemporary History, 33 (1998), 591-607.

27 For this period, see K. Rentola, 'The Soviet Leadership and Finnish Communism, 1944-48', in J. Nevakivi (ed.), Finnish-Soviet Relations, 1944-48 (Helsinki: University of Helsinki, 1994), pp. 216-48; K. Rentola, Niin kylmää että polttaa. Kommunistit, Kekkonen ja Kreml 1947-58 (Keuruu: Otava, 1997), pp. 17-114; K. Rentola, '1948: Which Way Finland?', Jahrbuch für Historische Kommunismusforschung (1998), pp. 99-124.

28 On the purges, see K. Rentola, Kenen joukoissa seisot? Suomalainen kommunismi ja sota 1937-45 (Juva: WSOY, 1994), pp. 23-74. 


\section{Comparative communisms: The Nordic example}

In the historiography of communism it has been usual to study the relation between the Communist International and one national movement. There has also been a great interest in finding out how the Communist International tried to get the national parties in conformity and how education in the schools of the Communist International and perhaps also terror in the Soviet Union served that intention. These studies have been and will be valuable in adding the knowledge on communism, but there is also a danger that they give a biased interpretation on communism. That is, there is a danger that the agenda of the communist movement is determined too strongly from the point of view of the central apparatus of the Communist International while important aspects of the national movements and national conditions may be neglected. Therefore studies which look at various working conditions and traditions of the national movements are also needed. In this respect comparative studies, quite rare in the historiography of communism, could be useful.

That has been the idea in the project Communism in the Nordic countries in 1917-1991 which has been going among the historians from the five Nordic countries since 2002. The project decided not to let everyone write about the movement in his/ her own country but to look at the five movements in regard to certain issues. In practice it meant comparison of organisational structures, working conditions, successes in the elections but also ideological and political platforms, even interpretation of some 
concepts, and their implementation, relation to other political parties and social strata, relation to the international communist movement and its activities. In this paper I shall present some aspects of this comparison and touch the formation, background and circumstances of the Nordic communist movements as also their attitude towards parliament and social democrats.

\section{Nordic communist movements}

The formation of the Nordic communist movements ${ }^{1}$ occurred mainly in two different ways; the long existing oppositions in the labour movement became communist parties, as in the Scandinavian countries and Iceland, or the main leadership of the labour movement became communists as in Finland. In Finland and Iceland the formation process was more complicated. The result was neither as straightforward as in the Scandinavian countries.

In all the Scandinavian labour movements an opposition against the leadership was born before the World War. These oppositions were displeased with the co-operation of the party leadership with the bourgeois centre. That co-operation was born during the parliamentary reforms at the end of $19^{\text {th }}$ century, and, according to the oppositions, indicated loss of socialist identity and submission of the labour movement to the bourgeois views. The oppositions also spoke against the war which became their distinctive feature after the break out of the World War in 1914.

In Sweden the opposition was organized in the Left Social Democratic Party of Sweden (Sveriges Socialdemokratiska Vänsterparti, SSV) as early as 1917. It joined the Communist International after its foundation in March 1919 and changed its name to communist party in 1921. In Denmark the oppositions had united into a communist party in 1920. The opposition was most influential in Norway and became the majority in the Norwegian Labour Party (Det Norske Arbeiderparti, DNA) in 1918, and the whole party joined the Communist International in 1919. The 
DNA was, however, against the centralization demands of the International and decided to resign the organization in 1923. Those willing to maintain the contacts with the Comintern founded the Communist Party of Norway (Norges Kommunistiske Parti, NKP) in November 1923. The relation to the Comintern was also the cause of two significant splits in Sweden; there were two communist parties in the country in 1924 and 1929-34.

In Iceland the national labour movement, consisting of both political and trade union activities, was born in 1916. The movement created contacts mainly with the Scandinavian social democratic parties, but there were also small groups which wanted to establish ties with the Communist International. Although there were different opinions concerning the international orientation, the communists were forced out of the common organization only in November 1930. Then they formed the Communist Party of Iceland (Kommunistaflokkur Íslands, KFÍ) which did not, however, live long as communists and part of the social democratic trade union activists founded the Socialist Unity Party in 1938. The party stayed outside the international labour organizations.

In Finland there were no oppositions towards the leadership of the Social Democratic Party but it was rather led by those who became communists. The birth of the Finnish communist movement was closely connected with the abortive revolution and the Civil War in 1918. The Red revolutionary leaders escaped to Soviet Russia in the spring 1918 and founded the Finnish Communist Party (Suomen Kommunistinen Puolue, SKP) in Moscow in August 1918. Due to its illegal status in Finland, the SKP was forced to work underground, and its principal organs were located in the Soviet Union until 1944.

The Finnish movement was, however, also born in Finland in 1919 as a reaction to the interpretations of the Social Democratic Party (Suomen Sosialidemokraattinen Puolue, SDP) which was revived in summer 1918 by those who had not participated in the revolution. The new leaders of the SDP condemned the revolution and took distance to the principles of the pre-Civil War party. This did not please all members who regarded it as 
accommodation to the views of the victors of the Civil War. These critics and the SKP representatives met in an attempt to win the majority in the SDP party congress in December 1919. As the attempt was not successful, the Socialist Workers' Party of Finland (Suomen Sosialistinen Työväenpuolue, SSTP) was founded by the critics in May 1920.

The movement left of the social democrats met with difficulties from the very beginning and in August 1923 all the activities of the SSTP were forbidden, its national and local leaders and the members of parliament arrested and sentenced to prison. After the ban the movement was organized into looser electoral, cultural and other associations. Even these organizations were forbidden in summer 1930. After that up to autumn 1944 Finnish communism, besides the SKP leadership in Moscow and its underground functionaries in Finland, consisted of individuals or small groups trying to work inside political organizations, trade unions and underground.

Thus communism was not in Finland and Iceland, though for different reasons, organised strictly in the communist parties as in the Scandinavian countries. Otherwise the movements stayed loyal to their traditions in the organisational questions, and followed the demarcations of electoral districts, though there were attempts to plant communist cells in the workplaces as instructed by the Communist International. The idea of a communist party as a cadre party was neither adopted but the Scandinavian and Icelandic maintained their mass party character while Finnish movement cherished at the same time the ideas of an underground cadre party (SKP) and a public mass party (those in Finland). These ideas, reflecting different traditions, were not always compatible as the SKP had a tendency to overestimate the significance of the underground work. In the other countries such an emphasis on the underground work was not present. ${ }^{2}$

All the Nordic communist movements had their ideological roots in the more or less German Social Democracy of the Second International. Besides Karl Kautsky's writings, Massenstreik-debate, Rosa Luxemburg's and Anton Pannekoek's contro- 
versies with Karl Kautsky inspired the Nordic movements. Their inspiration also included the American impact; many Finns, Swedes and Norwegians worked in America in the first decades of the 20th century and while returning to their native countries brought with them ideas of the American labour movement, particularly those of the militant Industrial Workers of the World (IWW). The American impact was obviously greater than that of the Russians; the Bolshevik ideas were not valued or considered appropriate in the Nordic countries, not even in Finland, though it was part of the Russian Empire. There were, however, contacts between the Russian revolutionaries and Nordic labour movements and some texts by the Bolsheviks were published in the Norwegian and Swedish labour papers during the war. ${ }^{3}$

These roots remained important when the new communist doctrine was received and interpreted. In Finland the movement, however, got also new impulses in the late 1930s through social democratic intellectuals who helped it out of isolation; these intellectuals got their inspirations from the Marxism of the Second International and the ideas of the contemporary West European socialists. ${ }^{4}$

\section{Nordic countries}

After the World War Nordic countries included two old nation states - Denmark and Sweden - and three young nation states - Norway, Finland and Iceland - of which Iceland was united with Denmark under a common king. In Finland a Civil War was fought during the winter and spring 1918 about whether the bourgeoisie or the workers would rule the independent country. Clashes in the Scandinavian countries in the late 1910s did not have as strong an effect on the division of the population or working conditions of the labour movement.

Due to the Civil War the ideological atmosphere of Finland differed significantly from that in the other countries. The winners of the war considered that they had fought for the independence 
and freedom of Finland against the Russians and their allies. This interpretation created the basis for the strong anti-communism in Finland; communism was continuously linked with the Soviet Union and a possible Soviet invasion of Finland. Thus anti-communism was much stronger in Finland than in the other countries, though the waves of Russophobia touched occasionally even them.

The conditions for revolutionary work in Finland were poor, and that part of the labour movement which criticised the existing forms of democracy and its authorities, spoke for another kind of society and friendly relations with the Soviet Union was eyed with suspicion. The communist party was a forbidden party, and persons having contacts with it or the Communist International or possessing their material were sentenced to prison for high treason. The possibilities for those left of the social democrats to form an organisation and to participate in the elections were also limited. ${ }^{5}$ In the other countries communists could take certain rights more for granted, and it was only during the Second World War that the Norwegian and Danish movements were forbidden and Swedish communist newspapers banned in $1940 .^{6}$ Thus the civil rights and freedoms were a more important issue for the Finns than for the Scandinavians and the Icelandic.

Divergent conditions regarding the rights and freedoms had other kind of effects, too. In Scandinavia and Iceland it was possible to present and discuss communist principles and to voice differing opinions whereas the restrictions in Finland hindered that. Divergent possibilities for open discussion created also basis for divergent relations between national communist movements and the Comintern; in the 1920s the questions of the Scandinavian parties were more often on the agenda of the International than Finnish issues. That was also due to the fact that the International trusted on the ability of the SKP leadership in Russia to guide the Finnish movement. It was only in 1929 that the Finnish question became usual in the meetings of the International. ${ }^{7}$

The Nordic countries were rather divergent regarding the position of the labour movement. In Scandinavia the labour move- 
ments were forcing their ways up to ruling positions. That was manifested in the elections where the percentage of the social democratic votes rose over 40 by the 1930s and in a regular social democratic participation in the government in all the Scandinavian countries in the 1930s. The success of the labour movement was partly based on the rise of the trade union membership. The importance of social democratic movement in Scandinavia was also due to a new policy where redistribution strategies got priority over demands of nationalisation and public ownership. By means of that policy the social democrats were able to meet the challenges of depression. Thus the social democrats were in a strong position regarding the determination of the terms of cooperation with other parties. ${ }^{8}$ In Iceland the social democrats never achieved similar positions but formed good relations with the party of the rural population, supported their government and from 1934 formed a government with them. The rapid growth of the degree of organisation improved the position of the trade unions in the labour market in the 1930s. ${ }^{9}$

The Finnish labour movement was pushed outside the political power centres after the Civil War, although it revived very quickly. Its influence on the discussions concerning the Finnish society was much weaker than that of the pre-Civil War labour movement. The week position of the labour movement was evident in the labour market where the employers did not want to accept trade unions as a negotiating partner but rather used lockouts and strike breakers against the workers. Their unwillingness also reflected the fact that the level of joining the trade unions was much lower - 20 to 25 percent - in Finland than in the other Nordic countries. The position of the labour movement did not change dramatically during the social democratic minority government in 1926-27. The social democrats were neither a dominant party as they joined the coalition government with the centre parties in 1937.

Thus the Scandinavian communist parties, in particular, had to work in the shadow of an advancing social democratic party, in Finland and Iceland they were more equal. Measured on the ba- 
sis of parliamentary elections their support was not very strong. In Sweden the SSV got eight percent of the votes in 1917, but the communist party three to six percent. In Norway the Labour Party got 32 percent of the votes in 1918, but the support of the communist party fell from the 6 percent in 1923 under 2 percent in 1932. In Denmark the share of the communists grew from 0.5 to 5 percent from the early 1920s to the late 1930s. In Finland the support of the movement varied between 10 and 15 percent in the 1920s, in the 1930s it was not allowed to participate in the elections. In Iceland the communists received three percent of the votes in 1931, in 1942 the Socialist Unity Party 18.5 percent and became stronger than the social democrats, which was rare in the Nordic countries. ${ }^{10}$ On this basis the Finnish movement in the 1920s and Icelandic movement in the early 1940s were among the strongest communist movements in the inter-war Europe. ${ }^{11}$

The Finnish movement also had a dominant role in the Finnish trade union and in all the central unions in the 1920s, while the Scandinavian parties could only boast on some local support. In Iceland the communist movement dominated the associations in northern Iceland and the largest association in Reykjavik.

\section{Parliamentary and extra-parliamentary activities}

The Communist International did not consider the organs of the bourgeois democracy appropriate for a society led by the workers and advocated forming of workers' own organs. It also gave high value for extra-parliamentary activities. That was easy to accept in the evolving Nordic communist movements of which the Scandinavian socialist oppositions had expressed their distrust of parliamentary activity as early as 1910s. Even the Finnish movement had seen the value of extra-parliamentary activities although committed to parliamentary strategy.

In Finland the belief in the parliamentary strategy had been strong; as the votes for the social democrats in the parliamentary elections rose from 37 to 47 percent in 1907-1916 and the 
party got a majority in the parliament in 1916, the social democrats could rely on becoming the ruling party in the country as soon as the ties to the Russian empire were broken. This belief was not shattered by the minor successes achieved or the loss of the majority position in October $1917 .{ }^{12}$ Although the Finnish labour movement gave emphasis on parliament, it did not forget that the parliamentary reform in 1906 was partly a result of large demonstrations. In 1917 demonstrations and various workers organisations were also significant. ${ }^{13}$ In the Scandinavian countries and Iceland the becoming communists gave stronger emphasis on the extra-parliamentary activities which were manifest especially in Norway in 1917-18. ${ }^{14}$

These traditions were preserved in the communist movements, and extra-parliamentary activities were more important for the Scandinavian and Icelandic movements than for the Finns. That also reflected divergent circumstances; in Finland the authorities had a tendency to ban communist demonstrations. Despite national and local strikes and various demonstrations organised by the labour movement or communists, the extra-parliamentary activities were, however, not as characteristic for the Nordic communist movements as for the Communist Party of Germany ${ }^{15}$.

Rejection was not the only instruction of the Communist International regarding parliament. According to the resolution made by the Second Congress in 1920, parliament could not, in conditions of imperialism, serve "as the centre of the struggle for reforms" or "for improving the lot of the working class", as it had done in the preceding epoch. For communists, parliament was useful only as a platform for making revolutionary agitation. In summer 1920 the Communist International was still affected by feelings of euphoria about the possibility of immediate revolution and believed that speeches from the parliament could "help the masses to shatter the State machine and parliament itself." ${ }^{16}$ Thus the influence of the agitation was regarded as a spark for immediate revolutionary actions.

It was easy for the emerging Scandinavian communist movements to accept the idea of using parliament as a tribune for agi- 
tation as it was familiar from the writings of Rosa Luxemburg and Anton Pannekoek. Luxemburg and Pannekoek did not, however, think that agitating from the parliament would bring immediate results as the Bolsheviks did. And it was in their spirit that the communist movements in Scandinavia and Finland interpreted the idea.

It was easy to follow the instructions of the Communist International in principle. Thus the SSTP declared that its main tasks in parliament would be to reveal "the rotten world of slaughter", arouse extra-parliamentary actions and force the bourgeois parliament into deadlock. ${ }^{17}$ In the Scandinavian countries the communist parties also expressed the need to give priority to extraparliamentary actions but probably warned about the danger of parliamentary illusions more clearly than the Finns. According to the DKP, for instance, it was important to reveal "the humbug democracy" of the country and to demonstrate opposition to the bourgeois society. ${ }^{18}$

It was usual for the movements, at least in Finland and Denmark, to demonstrate their arrival in the parliament. In Finland the members of the SSTP presented their principles in the opening session, pointed out white injustices of 1918 and demanded the release of the imprisoned reds. ${ }^{19}$ In Denmark the winning of two seats in 1932 was a significant moment, and the occasion was marked by a procession with red flags and 5,000 persons to the parliament where a meeting was held before the two members entered the parliament. ${ }^{20}$

In the long run it was, however, difficult to follow the guidelines. In Finland it became evident in 1922-23 that the speeches made in parliament did not produce any significant extra-parliamentary actions or bring the parliament to a standstill. For Finnish communism parliament was a platform to reveal injustices taking place in Finland. Thus the speeches from the parliament had at first a defensive character. In the latter half of the 1920s the motions in order to abolish the coercive organs of the state and to improve the economic position of the workers gave the parliamentary work more of an offensive character. The representatives 
of Finnish communism were, however, not able to determine the agenda of the parliament but usually had to respond to the proposals made by the government or other political groups. Little by little they more or less accommodated to the working methods of the parliament; they did not, for instance, use delaying tactics with long speeches. ${ }^{21}$

In Denmark the communist parliamentarians could, at least in the beginning, take advantage of the possibilities to speak more freely. In their speeches the communists attacked the government and other political parties and blamed them for acquiescing to Nazi Germany. This obviously reflected the politics of the third period but it was also due to the fact that no communist members were elected to any of the various committees of the parliament. The provocative behaviour of the communist representatives, though, diminished after the first years. ${ }^{22}$

Although the principles were similar, parliament had a divergent role and value for the Nordic movements. Finns were much more involved in the parliamentary work than their counterparts in the Scandinavian countries. This reflected the difficult conditions in Finland - it was safer to work in parliament. But the orientation was also due to the traditions of the labour movement which were not destroyed by the limited nature of what had been legislatively achieved, the Civil War or SKP's propaganda about the insignificance of parliament. Because of its relative strength Finnish communism could also occupy a more prominent position in parliament than the small Scandinavian parties.

The attitude of the Nordic communist movements grew more favourable towards representational democracy during the 1930s because of the threat of fascism and abolition of democratic rights. That was manifested in the platform of the Icelandic Socialist Unity Party which in 1938 declared as its important task to defend democracy against the aggressions of the dictatorial and reactionary parties. $^{23}$ 


\section{Social democrats}

In the communist movement the attitude towards social democrats varied from "den knutna nävens taktik" (tactics of clenched fist) to "handslagets taktik" (tactics of handshake), as Swedish historian Yvonne Hirdman put it. ${ }^{24}$ The first included attempts to demonstrate that the social democratic parties or their leaders did not work according to the interests of the workers. Branding of social democrats was a common feature in this tactics. The tactics of handshake consisted of slogans of co-operation and unity but often included also attempts to separate the social democratic workers from their leaders. For the Nordic communist movements the tactics of clenched fist was more usual.

The co-operation with the centre parties in the campaign for the parliamentary reform was one of the reasons for the emergence of the left oppositions in the Scandinavian social democratic parties in the first decades of the 20th century. The co-operation was more evident in Denmark and Sweden than in Norway where such a coalition was not formed as the parliamentary reform was carried out quickly. This co-operation led, according to the Swedish opposition, the social democratic party to lose its class character and to adjust itself to the dominating views which was fatal regarding the goal of emancipating people from the domination of the bourgeois thinking. The criticism turned gradually to accusations that the social democrats defended the existing society or capitalism. That accusation was supported by divergent attitudes towards militarism; for the oppositions it was a class phenomenon, not a national question as for the party leaderships. $^{25}$

Similar reasons were also crucial for the division of the labour movement in Finland. The re-founded Social Democratic Party regarded as its task to organize a labour movement which would concentrate on work in the representational organs and try to achieve co-operation with the centre parties. Its attitude towards extra-parliamentary activities was rejecting. These prin- 
ciples were against those of the pre-Civil War party and aroused dissatisfaction among those who had participated in the revolution. From their perspective the SDP adjusted itself to the views of the victors of the Civil War. The feelings that the social democrats supported the existing society were strengthened by the fact that the SDP, while trying to prevent the formation of the united bourgeois front, drifted away from the stands of the old Finnish labour movement in questions concerning the defence of the native country, armament and Suojeluskunnat, the independent right wing military organisation. ${ }^{26}$

The fact that social democrats wanted to participate in the government during capitalism was for the Nordic communists a proof of their commitment to defending the existing society. The attitudes of the social democratic minority government in 1924-26 towards foreign and defence politics, in particular, gave Swedish communists basis to characterize social democrats as the "third party of the bourgeoisie". 27 Those were also central issues as Finnish communism judged the social democratic minority government which was in office from December 1926 to December 1927. Negative assessment set aside the fact that movement's working possibilities improved during the government. ${ }^{28}$ In Norway the very short experience of the labour government in 1928 did not give communists as much cause for this kind of accusations but rather caused puzzlement within the communist party. ${ }^{29}$ In Iceland the passive support given by the social democrats to the government from 1927 was not as significant controversial subject as in the other countries. ${ }^{30}$ In the 1930s when the social democratic governments were able to produce improvements for the workers it became more difficult for the Scandinavian communist parties to brand the social democrats for their participation in the government. That was especially the case in Norway where the DNA launched a radical crisis programme in the early 1930s. To brand them as 'social fascists' was not convincing. Tones of the Scandinavian communists became more conciliatory in the latter half of the 1930 s. $^{31}$ 
As the social democrats were characterised as defenders of the capitalist system, the idea of united front was not very usual in the Nordic movements in the 1920s; it was utilized primarily by Finns and Norwegians. The united front was supposed to be an offensive idea with demands concerning workers' daily interests but the proposals in Finland in January 1923 and in Norway at the turn of 1923-24 were rather defensive ${ }^{32}$ Even the proposals on co-operation in the elections - in Finland in 1922 and 1924, in Norway and Denmark in 1924-25 - were attempts to safeguard the participation of communists in the elections. ${ }^{33}$ In the mid1930s the proposals in the Scandinavian countries got more offensive character, though their orientation against fascism gave them also defensive tones. ${ }^{34}$

Other kind of co-operation between social democrats and communists was also rare. In Finland, for instance, various campaigns were organized separately, and even the campaigns for various reforms became manifestations of rivalry. That was also the case with the May Day demonstrations which were usually organized separately in Finland. In the Scandinavian countries the variation was larger, and the communists in many cases participated in the social democratic demonstrations. ${ }^{35}$

The situation reflected the negative attitude of the Scandinavian social democratic parties which were not usually willing to negotiate about co-operation with the small communist parties but rather demanded communists to join the social democratic movement. There was, perhaps, more room for discussions in Norway as the DNA did not insist that the united party should be a member in any of the internationals. ${ }^{36}$

That obviously created the background for the proposals made in Norway about the organisational forms of the labour movement. During the summer 1925 in the discussions between the trade union men evolved an idea of creating a "Labour party" under which all the three labour parties and the trade union movement would form an electoral alliance and organize joint campaigns. The parties would, however, maintain their independence and international commitments. The NKP initially opposed the 
idea but accepted it under direction of the Communist International. The involvement of the International, however, contributed to the refusal of the DNA. It also discredited the idea among the workers outside the NKP and created better understanding between the two other labour parties which were united in January 1927. NKP's response was to launch the idea of collection of communists, radical trade unions and other organisations to the Arbeiderklassens samlingsparti (The Unity Party of the Working Class), which would compose a joint action programme. The new party did not, however, appeal to the left wing of the DNA as the communists anticipated, although the Mot Dag, the organisation of the intellectuals, joined. ${ }^{37}$

In 1936-38 the NKP was again willing to participate in the unity negotiations with the DNA, and in order to demonstrate its willingness the party withdrew its candidates in those districts where they would threaten the election of the DNA candidates. During the negotiations an understanding was reached in most questions, but the DNA broke the negotiations in January 1938 explaining that the NKP still gave preference to the Comintern slogans over the solidarity to the Norwegian working class. Thus the DNA clearly had no need to become united with a party whose influence was minimal and which, by its connections to the Soviet Union, gave bad colour to the whole movement. ${ }^{38}$

In Iceland the communists spoke for the united front and co-operation since the mid-1930s, but the prospects seemed dark as the social democrats rejected all the proposals. It was only after the advance of communists in the parliamentary elections in 1937 that they showed some willingness to listen to the communists who were not initially willing to discuss the affiliation of the parties but wanted to speak about separation of political and trade union activities. They accepted the negotiations between the parties, although the Comintern instructions gave more emphasis on unity from below. In the negotiations the parties agreed on the need of uniting the parties and on leaving the new party outside the internationals. But the disagreement on questions concerning the character and the organisational form of the party seemed to 
be insurmountable. The social democratic leaders were, however, used to expel dissidents and expelled also those who insisted on the unification of the parties. Thus they created conditions for the formation of the Socialist Party by the communists and those expelled. ${ }^{39}$

These kinds of proposals were not presented in the other countries. In spite of their proportional strength in the 1920s, Finnish communists never made such attempts because the SKP leaders were afraid of losing their influence on Finnish communists in Finland. On the other hand, this kind of a new party was not needed in Finland because from the perspective of the communist party there was an organisation that was between the communists and social democrats and that was led by the communists. Strong positions in the trade unions obviously strengthened this feeling.

\section{Trade unions}

The polarisation between communists and social democrats was strengthened by the struggles for the leadership, character and international orientation of the common labour organisations, especially trade unions. These struggles were most intense in Finland where Suomen ammattijärjestö (SAJ), the Finnish trade union movement, and the largest unions were dominated by Finnish communism in the 1920s. The leaders of the SAJ and the unions were, however, not eager to follow the instructions of the SKP leadership but rather followed traditions of the trade union movement. The SAJ leadership was also challenged by the social democrats who argued that they should have the leadership in the trade unions because they got more votes in the parliamentary elections. The social democrats began to make plans for their own trade unions in 1923 and again in 1928 - that resulted in their withdrawal out of the SAJ in May 1929. That made it easier for the authorities to forbid the SAJ as a communist organisation in summer $1930 .^{40}$ 
The international orientation of the trade unions created also disputes between communists and social democrats. In Finland the SAJ had decided, after the vote among the membership in 1921-22, to resign from the Amsterdam International and to join the Red Trade Union International (Profintern). The latter decision was, however, not put into practice in order to keep the SAJ united and to protect its existence. The international orientation was, however, a constant controversial issue as the social democrats insisted on joining the Amsterdam International, while the leaders of the SKP advocated close co-operation with Profintern and the Russian trade unions and the SAJ leadership tried to balance between these two and preserve the unity in the trade unions. The ideas of co-operation with Russians got, however, priority in the last years of the 1920s and contributed to the dissolution of the SAJ. ${ }^{41}$

The role of the communists in the trade unions was much weaker in the Scandinavian countries than in Finland. The attempts to form a revolutionary opposition in the trade unions were most successful in Sweden where the unity committee, formed in 1926, attracted 10 to 20 percent of the members of the Landsorganisation (LO), the Swedish trade union movement. The committee, however, lost them as the membership in the committee was declared contradictory to the membership in LO in April 1929. ${ }^{42}$

In Iceland there were no attempts to gather the communist trade union members into a special organisation. In the $1920 \mathrm{~s}$ and 1930s the communists, however, had a strong position in the northern associations and by the end of the 1920s also in Reykjavik. During the depression and under the social democratic pressure they managed to maintain these associations as negotiating partners with the employers, although the social democrats founded new unions in those regions which were dominated by the communists. Thus, it was possible to regard social democrats as "splitters" of the trade union movement. The communists did not, however, think of forming special red trade unions but fought for the possibility to work inside the Icelandic LO. ${ }^{43}$ 
In Finland the SKP instead decided to create a special red trade union after the ban of the SAJ. That was partly due to the unwillingness of those who had been members in the SAJ to join Suomen ammattiliittojen keskusjärjestö (SAK), the new trade union movement founded by the social democrats in October 1930. The communists also hoped to get the unorganized workers interested. The red trade unions could not, however, attract members outside the SKP. In spite of that, it was only in 1933 that the party began to change its orientation. In July 1934 the party decided to give up the red trade unions entirely and urged its members to join the SAK. The improvement of economic situation was obviously a more important factor in the growth of the SAK membership. ${ }^{44}$

Thus, by the end of the 1930s all the Nordic communist movements had abandoned their attempts to form a special communist organisation in the trade unions and worked inside the unions doing best in Iceland. In Finland the movement also got strong foothold in the unions of building and transport workers. ${ }^{45}$

The Scandinavian social democratic trade union leaderships were obviously more willing to take actions against "splitting" activities than the communist leadership in Finland. That was due to the conditions; it was important for the representatives of Finnish communism to maintain the formal unity of the trade union movement in order to avoid the interference of the state authorities, in the Scandinavian countries this need was non-existent. But the difference was also due to different bargaining conditions. In order to make their politics accepted beyond working class the Scandinavian social democrats had to prove that their trade union politics was reliable. Therefore they started to subordinate the trade union movement to the new line of the social democratic party. That indicated increased centralization and made local bargaining and direct democracy cherished by the communists more difficult. ${ }^{46}$ In Finland where the employers did not want to enter collective bargaining this kind of need was not present, although there was certain disagreement between the workers in the northern Finland and the SAJ leadership regarding the strikes 
in the latter half of the $1920 \mathrm{~s}^{47}$ These disputes surfaced again in the SAK in the latter half of the 1930s; the social democratic leadership wanted to keep the local industrial actions initiated by the communists under strict control. That aroused dissatisfaction, and the complaints about centralized power became usual during the last years of the 1930s. ${ }^{48}$

Although the Nordic communist movements were willing to be part of the international communist movement and adopt the message of the new communist doctrine, they also maintained a lot of their traditions. That was obvious in the questions regarding the organisation; all the movements stayed more or less loyal to the earlier organizational principles of the national labour movements. In Finland, in particular, parliament remained a central forum for the communist movement. In the Scandinavian countries criticism towards social democratic parties or their leaders had its roots in the earlier behaviour of the left, although it was considerably strengthened by the communist doctrine.

National conditions also had an influence on the character of the Nordic communist movements. The fact that the Finnish movement had to work in two countries and under strict control by the authorities made the Finnish movement more reserved than the Scandinavian movements regarding the discussions on the communist principles. The underground work was also considered important only by the Finnish movement. In spite of the criticism towards social democrats in all countries, the communists in Norway and Iceland were more willing to negotiations concerning organisational unity than in Sweden and Denmark. That was partly due to the differences of the character of the social democrats; in Norway the DNA was more flexible in regard to the international orientation of the labour movement than the social democrats in Denmark or Sweden.

The differences were partly due to the position of communists within the labour movements and due to the position of the la- 
bour movement in the Nordic societies. In the Scandinavian countries the social democrats dominated the labour movement and were also able to attain considerable influence in the societies as a whole. In Iceland and in Finland the communist movements were in a better position to compete with social democrats for the traditions of the labour movement. In Finland that was manifested in strong positions within the trade union movement.

The project on the Nordic communist movements has revealed that studying several movements simultaneously helps to understand their special features. That is not as easy by focusing only on one movement and its relation to the Communist International. Comparison also helps to understand the interpretation of a general doctrine or implementation of general instructions. A certain comparison can even be useful for understanding the international character of the communist movement. The project has also revealed that there is not always enough knowledge on various questions. That may reflect the fact that some questions have been more important for one movement than for another. But it can also reflect different traditions in studying communism.

\section{Notes}

1 For instance, Werner Schmidt, Kommunismens rötter i första världskrigets historiska rum. En studie kring arbetarrörelsens historiska misslyckande. Stockholm: Symposion 1996; Jan Bolin, Parti av ny typ? Skapandet av ett svenskt kommunistiskt parti 1917-1933. Stockholm: Acta universitatis Stockholmiensis. Stockholm Studies in History 2004; Jörgen Bloch-Poulsen and Morten Thing, Danmarks kommunistiske parti 1918-1941. Viborg: Politisk revy 1979; Kurt Jacobsen, Aksel Larsen - en politisk biografi. Vindrose. København 1996 (1993); Einhart Lorenz, Norwegische Arbeiterbewegung und Kommunistische Internationale 1919-1930. Untersuchung zur Politik der norwegischen Sektion der Kommunistischen Internationale. Pax Förlag, Oslo 1978; Stefán F. Hjartarsson, Kampen om fackföreningsrörelsen. Ideologi och politisk aktivitet på Island 1920-1938. Uppsala 1989; Tauno Saarela, 
Suomalaisen kommunismin synty 1918-1923. Tampere: KSL, 1996; Tauno Saarela, 'Kommunistinen internationaali ja suomalainen kommunismi 1919-1935', in "Kallis toveri Stalin!" Komintern ja Suomi. Edited by Natalia Lebedeva, Kimmo Rentola and Tauno Saarela. Helsinki: Edita 2002.

2 On the organizational questions, Ole Martin Rönning's manuscript, 'Party organisations'.

3 Einhart Lorenz, Arbeiderbevegelsens historie. Enn innföring. Norsk sosialisme i internasjonalt perspektiv. 1. del 1789-1930. Drammen: Borgens förlag 1972, 87-96, 142; Jorunn Bjørgum, Martin Tranmael og radikaliseringen av norsk arbeiderbevegelse 1906-1918. Oslo: Universitetsforlaget AS 1998, 24-25, 42-43, 121-122, 226-236, 499-516; Schmidt, Kommunismens, 9196, 100-109; Aleksander Kan, Hemmabolsjevikerna. Den svenska socialdemokratin, ryska bolsjeviker och mensjeviker under världskriget och revolutionsåren 1914-1920. Stockholm: Carlssons 2005, 49-470; Jouko Heikkilä, Kansallista luokkapolitiikkaa. Sosiaalidemokraatit ja Suomen autonomian puolustus 1905-1917. Tampere: SHS 1993, 227-237; Leevi Norrena, Talonpoika, pohjalainen - ja punainen. Tutkimus Etelä-Pohjanmaan Järviseudun työväenliikkeestä vuoteen 1939. Tampere: SHS 1993, 191-234.

4 Saarela, 'Kommunistinen internationaali', 50.

5 Lars Björne, "... syihin ja lakiin eikä mielivaltaan". Tutkimus Turun hovioikeuden poliittisista oikeudenkäynneistä vuosina 1918-1939. Helsinki: Suomalainen lakimiesyhdistys 1977, 41-107, 201-231; Saarela, Suomalaisen kommunismin, 179-183, 352-355.

6 Yvonne Hirdman, Sverges kommunistiska parti 1939-1945. Stockholm: Allmänna Förlaget 1974, 23-50; Terje Halvorsen, Mellom Moskva og Berlin. Norges Kommunistiska Parti under ikke-angrepspakten mellom Sovjet-Unionen og Tyskland 1939-1941. Oslo: Falken Förlag 1996, 19-20; Jacobsen, Aksel Larsen, 263-268

7 Tauno Saarela, 'Den finska, skandinaviska och nordiska kommunismen på 1920-talet', in Pauli Kettunen (red.) Lokalt och internationellt. Dimensioner $i$ den nordiska arbetarrörelsen och arbetarkulturen. Tammerfors: Sällskapet för forskning i arbetarhistoria i Finland 2002, 112-113.

8 Nils Elvander, Nordisk arbetarrörelse. Stockholm: LiberFörlag 1980, 50-58, 74-89, 92-93; Gösta Esping-Andersen, 'The Making of a Social Democratic Welfare State', in Creating Social Democracy. A Century of the Social Democratic Labor Party in Sweden. Edited by Klaus Misgeld, Karl Molin, and Klas Åmark. The Pennsylvanian State University. University Park 1992, 35-45.

9 Thorleifur Fridriksson, Den gyldne flue. De skandinaviske socialdemokratratiers relationer til den islandske arbejderbevaegelse 1916-56. Internationalisme eller indblanding? Århus: SFAH 1990, 92-93.

10 Elvander, Nordisk, 50-55; Hannu Soikkanen, Kohti kansanvaltaa 1. 18991937. Vaasa: SDP 1975, 411-414, 430-432, 467-468, 490, 520-521, 545548. 
11 The Communist Party of Bulgaria got 20,4 \% of the votes in 1920, Kommunistische Partei Deutschlands 16.9 \% of the votes in November 1932, Communist Party of France 15,3 \% in 1936 and the Communist Party of Czechoslovakia 13,2\% in 1925.

12 Soikkanen, Kohti kansanvaltaa, 186-198.

13 Anthony F. Upton, The Finnish Revolution 1917-1918. Minneapolis: University of Minnesota Press 1980, 31-34.

14 Lorenz, Norwegische, 54-70; Bjørgum, Martin Tranmael, 71-93, 124-133, 213-216; Bloch-Poulsen-Thing, Danmarks, 16-26.

15 On German communists, Eric D. Weitz, Creating German Communism, 1890-1990. From Popular Protest to Socialist State. Princeton: Princeton University Press 1997, 160-187.

16 The Communist International 1919-1943. Documents. Selected and edited by Jane Degras. Volume I 1919-1922. London: Oxford University Press 1956, 7-16, 150-155.

17 Saarela, Suomalaisen kommunismin, 275-279.

18 Lorenz, Norwegische, 206; Jacobsen, Aksel Larsen, 128.

19 Saarela, Suomalaisen kommunismin, 279-280.

20 Jacobsen, Aksel Larsen, 125.

21 Saarela, Suomalaisen kommunismin, 281-284.

22 Jacobsen, Aksel Larsen, 134-136.

23 Elfar Loftsson, Island i NATO - partierna och försvarsfrågan. Göteborg: Göteborg Studies in Politics 1981, 60-61.

24 Hirdman, Sverges, 90.

25 Elvander, Nordisk, 30-33, 37-46; Schmidt, Kommunismens rötter, 90-98, 104-109, 142-144; Bolin, Parti, 43-47, 61-68.

26 Saarela, Suomalaisen kommunismin, 122-130, 179-186.

27 Bolin, Parti, 144-145; Branting som borgarklassens försäkringspremie. SKP. Stockholm 1924; Socialdemokratin. Borgarnas tredje parti. Frams förlag. Stockholm 1925.

28 Saarela, 'Kommunistinen internationaali', 27.

29 The government was in office from 27 January to 15 February 1928, Lorenz, Norwegische, 270-273; Per Maurseth, Gjennom kriser till makt (19201935). Arbeiderbevegelsens historie i Norge 3. Tiden Norsk Förlag. Oslo 1987, 439-449; Den såkalte “Arbejderregjerings" loerdomer. Åpent brev till partiets medlemmer og alle klassbevisste arbeidere. Andelsforlaget Ny Tid. Oslo 1928, 6-13.

30 Hjartarsson, Kampen, 55-56.

31 Bernt Kennerström, Mellan två internationaler: Socialistiska Partiet 192937. Arkiv för studier i arbetarrörelsens historia. Kristianstad 1974, 96-98; Tore Pryser, Klassen og nasjonen (1935-1946). Arbeiderbevegelsens historie $i$ Norge 4. Tiden Norsk Forlag. Oslo 1988, 38, 83-86.

32 Saarela, Suomalaisen kommunismin, 295-296; Einhart Lorenz, 'Einheitsund Vereinigungsversuche in Norwegen. Einheits-, Volksfront- und Vereinigungsversuche vor 1940', in Einheitsfront, Einheitspartei. Kommunisten 
und Sozialdemokraten in Ost- und Westeuropa 1944-1948. Herausgegeben von Dietrich Staritz und Hermann Weber. Verlag wissenschaft und Politik. Köln 1989, 393.

33 Saarela, Suomalaisen kommunismin, 268-269; Saarela, 'Kommunistinen internationaali', 29; Maurseth, Gjennom kriser, 410-411; Jacobsen, Aksel Larsen, 43-44.

34 Jörgen Bloch-Poulsen, Hans Erik Auland Frandsen og Morten Thing,'Planökonomie og folksfront. Omkring Socialdemokratiet og DKP i mellenkrigstiden'. Studier i historie og tekstvidenskab fra Roskilde universitetscenter. Köbenhavn 1979, 122-126; Jacobsen, Aksel Larsen, 136-139, 155-156, 233-234, 243-246; Terje Halvorsen, 'Enhet med "socialfascisterne?', Tidskrift for arbeiderrbevegelsens historie 2/1985, 140-147; Kennerström, Mellan två, 79-84, 160-167; Lars Björlin, 'Ett aktionsprogram för enhet. Kring SKP och enhetsfrontspolitiken under 1930-talet', in Av kärlek till arkiv: festskrift till Erik Norberg. Riksarkivet. Stockholm 2002, 491-496.

35 See e.g. Alustuksia verotuskysymyksestä. Helsinki 1928; Helsingin työväki kokoontuu vappuna entiseen tapaan, Työväenjärjestöjen Tiedonantaja 26 March 1928; Olsson, op. cit., 116-129; Maurseth, Gjennom kriser, 410.

36 Lorenz, 'Einheits- und Vereinigungsversuche', 393.

37 Lorenz, Norwegische, 230-255.

38 Ole Martin Rönning, 'NKP, Komintern og folkefrontpolitikken', Arbeiderhistorie 2003, 150-153.

39 Thorleifur Fridriksson, Den gyldne flue. De skandinaviske socialdemokratratiers relationer til den islandske arbejderbevaegelse 1916-56. Internationalisme eller indblanding? SFAH. Århus 1990, 49-66; Jón Ólafsson, The Comintern Experience: How it influenced the Icelandic Left, unpublished paper, Russian Studies, Columbia University 1998, 13-17.

40 E.g. Pauli Kettunen, Poliittinen liike ja sosiaalinen kollektiivisuus. Tutkimus sosialidemokratiasta ja ammattiyhdistysliikkeestä Suomessa 1918-1930. SHS. Jyväskylä 1986, 355-380, 424-445.

41 Kettunen, Poliittinen liike, 363-365, 372-380.

42 Kennerström, Mellan två, 16-21, 44-47, 55-69; on Norway, Maurseth, Gjennom kriser, 457-458; on Denmark, Jörgen Bloch-Poulsen-Morten Thing, 'DKP's faglige politik 1930-35: Den revolutionaere Fagopposition', Historievidenskab 3/1976, 3-93.

43 Hjartarsson, Kampen, 117, 122-124, 176-177.

44 Saarela, 'Kommunistinen internationaali', 48-49.

45 Marjaana Valkonen, Yhdessä elämä turvalliseksi. Suomen Ammattiyhdistysten Keskusliitto 1930-1947. SAK. Helsinki 1987, 219-221.

46 See e.g. Bengt Schüllerqvist, Från kosackval till kohandeln. SAP:s väg till makten (1928-33). Tiden. Ktistianstad 1992, 117-121, 138-142, 175-193.

47 Jorma Puuronen, Liike kylässä: Työväenliikkeen organisoituminen Kolarin Venejärvellä vuosina 1925-1950. Rovaniemi 1998, 52-56.

48 Valkonen, Yhdessä, 239-258. 



\section{Nordic communists in the Communist International}

The Communist International (Comintern), founded in March 1919, aimed to be a world party and the centre of all communist activities; the parties joining it would have to strictly follow its instructions on policies (on the background and formation of the Communist International, see e.g. Kirby 1986; McDermott and Agnew 1996: 1-14). These principles seemed to promise contacts between various national communist movements but at the same time to limit them to one-to-one relationships with the central organs of the Communist International. How did these principles relate to the attempts to pursue regional interests shared by various national parties inside the Comintern? In this chapter I try to determine whether the Nordic communists, whose heritage included the common meetings of the Nordic labour movements, attempted to form a united group in order to pursue their common interests within the Comintern. I focus on the question of who was to define and organize this possible cooperation.

\section{Nordic communist movements}

The formation of the Nordic communist movements occurred mainly in two different ways. In the three Scandinavian countries and Iceland, long-existing opposition factions in the socialdemocratic parties turned to communism, while in Finland it was rather the mainstream of the labour movement that became communist. 
In all the Scandinavian labour movements, opposition to the leadership was formed before the First World War (on the formation of the opposition parties and the Scandinavian communist movements, see Lorenz 1978; Bloch-Poulsen and Thing 1979; Jacobsen 1996; Schmidt 1996; Bolin 2004). The opposition criticized the party leadership for its cooperation with the bourgeois centre parties, which was born during the parliamentary reforms. According to the opposition, this cooperation contributed to the submission of the labour movement to bourgeois views and to the loss of its own socialist identity. The opposition also expressed their anti-militarism, which became even more pronounced after the outbreak of the First World War.

Out of this opposition to the social democratic leadership grew the Scandinavian communist parties. In Sweden the opposition organized as early as 1917 to form the Left Social Democratic Party of Sweden (Sverges Socialdemokratiska Vänsterparti, SSV). After the foundation of the Communist International in March 1919 it joined the new organization and changed its name to the Communist Party in 1921. In Denmark the oppositional groups had united to form a communist party a year earlier. In Norway the opposition became the majority in the Labour Party in 1918, and the whole party joined the Communist International in 1919. The Norwegian Labour Party did not, however, accept the International's demands for centralization, and decided to resign from the organization in 1923. Therefore, those willing to maintain contacts with the Comintern founded the Communist Party of Norway in November 1923. Disagreements with the Comintern were also the cause of two significant splits in Sweden in 1924 and 1929.

In Iceland the national labour movement was born only in 1916. It was special in the respect that political and trade union activities were not separated into different organizations. The Icelandic labour movement created contacts primarily with the Scandinavian social democratic parties, although there were also small groups that wanted contacts with the Comintern. Opinions differed regarding the international orientation, but the organi- 
zational division of the movement took place only in November 1930 as the communists were forced out of the movement and formed their own party. The Communist Party of Iceland was, however, not long-lived as the communists and some of the social democratic trade union activists founded the Socialist Unity Party (Sameiningarflokkur alpýðu - Sósíalistaflokkurinn) in 1938, which did not join any of the international labour organizations (Hjartarsson 1989; Fridriksson 1990).

There were no similar opposition groups in Finland, but the whole Social Democratic Party (Suomen Sosialidemokraattinen Puolue, SDP) was, on the basis of its success in the parliamentary elections, looking to become the ruling party in the country via parliamentary means as soon as the ties with the Russian Empire were broken. The Russian revolution opened up opportunities but also intensified the question of who was to rule in an independent Finland. The struggle for power eventually led to armed confrontation and the Civil War in winter and spring of 1918 (on developments in Finland in 1917-18, see e.g. Upton 1980; Alapuro 1988). The division in the Finnish labour movement took place only during and after these events. The formation of the Finnish communist movement was also special in that it took place in two countries: in Finland and Soviet Russia (on the formation of Finnish communism, see Saarela 1996: 26-166; 2002b: 15-19).

The red revolutionary leaders, most of whom had also belonged to the leadership of the SDP, escaped to Soviet Russia in spring 1918 and founded the Finnish Communist Party (Suomen Kommunistinen Puolue, SKP) in Moscow in August 1918. The new party gave up all the earlier forms of activity - that is, work in parliament, trade unions and cooperatives - and propagated armed revolution. By 1919-20, however, it had to admit that other forms of activity were also necessary.

In Finland the movement was born in 1919 as a reaction against the interpretations of the SDP, which was revived in summer 1918 by those who had not participated in the revolution. The new leaders of the SDP condemned the revolution and distanced themselves from the principles of the pre-Civil War party 
by emphasizing the importance of work in representative organs and cooperation with the centre parties. This did not please all members, who regarded it as accommodating the views of the victors of the Civil War. Despite their different interpretations of the pre-Civil War labour movement, these critics and the representatives of the SKP met in an attempt to win the majority at the party congress of the SDP in December 1919. As the attempt was not successful, the Socialist Workers' Party of Finland (Suomen Sosialistinen Työväenpuolue, SSTP) was founded by the critics in May 1920.

The activities of the new movement met with difficulties from the very beginning because of repression by the authorities. In August 1923 all the activities of the SSTP were prohibited, and its national and local leaders and members of parliament were arrested and later sentenced to prison. After the ban no new socialist party was founded but the movement was organized into looser electoral, cultural and other associations. Even these organizations were prohibited in the summer of 1930. From then on until autumn 1944, Finnish communism, except for the SKP leadership in Moscow and its underground functionaries in Finland, consisted of individuals and small groups trying to work inside political organizations, trade unions and underground.

On the basis of parliamentary elections, communism was not a very strong force in the Nordic countries. In Finland its support varied between 10 and 15 per cent in the 1920s; in the 1930s the movement was not allowed to participate in the elections. In Sweden the SSV won 8 per cent of the votes in 1917, but the Communist Party 3-6 per cent. In Norway the Labour Party received 32 per cent of the votes in 1918, but support for the Communist Party fell from 6 per cent in 1923 to less than 2 per cent in 1932. In Denmark the share of communists grew from 0.5 per cent to 5 per cent from the early 1920s to the late 1930s. In Iceland the growth was much stronger; in 1931 the communists received 3 per cent of the vote, whereas in 1942 the Socialist Unity Party had 18.5 per cent, thereby becoming stronger than the social democrats, a rare occasion in the Nordic countries (Soikkanen 1975: 
411-14, 430-32, 467-68, 520-21, 545-48; Elvander 1980: 50-55; Loftsson 1981: appendix 3).

In the Scandinavian countries, the communist parties were working in the shadow of the strong and influential social democratic parties. The strong position of the social democrats was indicated by their share of roughly 40 per cent of the votes in the elections in the 1930s and by their constant participation in the government. Their position was not as strong in Finland and Iceland. In Finland especially, the labour movement was in a second-rate position after the Civil War until the late 1930s (Elvander 1980: 50-58, 74-89,92-93).

\section{Scandinavian committee, central committee and federation}

The Communist International was initially very far from being a world party; it did not even have contacts in every country in Europe. Neither did it have a monopoly on defining the character of the activities carried out under the name of communism. There were other attempts to do that, too. That was evident in the foundation of the first organizations in the Nordic countries; besides the leadership of the Communist International, the Scandinavian left socialists and the Finnish red refugees in Stockholm expressed ideas on Nordic cooperation.

The interest of the Communist International in founding an organization in Scandinavia was connected to the fact that the Nordic countries, Sweden and Norway in particular, were important for Soviet Russia and the Communist International if they were to break down the blockade imposed on Soviet Russia from 1918 to 1920. Stockholm was therefore among the first cities where an organization of the Communist International, the Scandinavian committee, was founded in the spring of 1919 - the bureaus of the Communist International in Amsterdam and Berlin were opened only in the autumn of the same year. The choice of Stockholm as the location for the committee was based on its 
importance as a meeting place of the international labour movement in 1917-18. The Swedish left social democrats had also created close contacts with Russian revolutionaries during the war (Kan 2005: 279-379, 436-39).

The Swedes were involved in other attempts, too. In December 1919 a Nordic meeting was arranged in Stockholm as a common forum for the Swedish Left Social Democratic Party, Danish socialists and the Norwegian Labour Party. They had all expressed their solidarity with the Russian revolution and with the Communist or 'Third International. The Stockholm meeting nominated a Scandinavian central committee with representatives from all three parties (Saarela 2002a: 105; Kan 2005: 442-43).

This kind of organization reflected the traditions of cooperation between the labour movements in the Nordic countries. The Scandinavian labour movements in particular had been engaged in this cooperation from the late 1880s, and the Finns also participated in joint meetings from 1907. The Finns, however, were not involved in the Scandinavian committee for cooperation founded in 1913. The division of the labour movement during the First World War obviously made contacts livelier in Scandinavia, as various groups tried to seek support for their ideas in the neighbouring countries (Grass 1974: 55-80; Svensson 1986: 17-73; Schmidt 1996: 145-49, 157-68, 177-79).

Finnish red refugees in Stockholm also had ideas concerning the promotion of Nordic cooperation in 1919-20. Their ideas reflected the spirit of an immediate world revolution, as they planned for military cooperation to support the revolution due to break out in Finland in spring 1919. These plans had no real basis in their homeland and did not materialize. The red refugees started instead to make plans to send armed men into Karelia to protect the Russian revolution and to fight the British situated in the Murmansk area. This plan, as well as ideas for creating a Scandinavian Soviet Republic, did not materialize either. These ideas served more as a bait in order to get Bolshevik support for the Karelian Workers' Commune, founded by the Red Finns in 
1920 (Saarela 2002a: 105-6; on Red Finns in Karelia, Kangaspuro 2000: 42-46).

The various plans for Nordic communist cooperation indicate that communist activities did not have a thoroughly centralized character. Rather, various groups tried to present themselves as the mouthpiece of the new revolutionary orientation.

Although there were various attempts in Stockholm to form an international organization, the Scandinavian committee of the Communist International held a position of priority. This committee was initially a kind of information, postal and travel agency, perhaps also a bank. That is, the committee aimed to make contacts with leftist groups in Western Europe by correspondence and personal visits and to assist them financially with money it obtained from the Bolsheviks. The activities of this committee also included sending two Finns to build a Red Army in Great Britain. As the Communist International managed to make direct contact with the evolving communist parties in Western Europe, the Scandinavian committee lost these tasks (Kan 2005: 436-39, 455-62). ${ }^{1}$

The decline of the importance of the Nordic countries was also reflected in the Scandinavian committee, and its activities waned in 1921. Some contacts, however, remained; in April 1922 the representatives of the communist parties of Sweden, Denmark and Finland, the Norwegian Labour Party and the Socialist Workers' Party of Finland held a meeting in Sweden. ${ }^{2}$

Difficulties were met by communists everywhere in 1923. In Finland the Socialist Workers' Party was banned in August; in Sweden the party was beleaguered by inner struggles; in Norway the Labour Party had left the Comintern and the communist party was founded. These problems motivated closer cooperation. On the initiative of the newly established Communist Party of Norway a joint meeting was arranged in January 1924. During the meeting the participants decided to form a Scandinavian federation as a forum for cooperation of the Nordic communist parties. $^{3}$ 
The meeting tried to justify the cooperation of the Nordic communist parties by declaring that the capitalist class intended to form a united front in the Nordic countries. The argument was very general and perhaps an attempt to revive the spirit of world revolution. There was, though, a seed of truth in this, as the Nordic employers' organizations had begun to have contacts with each other. This did not mean, however, that there would not have been stiff competition between, for instance, the Swedish and Finnish wood and paper industries.

The main targets of the Scandinavian federation were the trade union questions. It initiated solidarity campaigns for the striking Norwegian metal workers. In November 1924 the federation had to take a stand on the international orientation of the Nordic trade unions. Although this was an important issue in the communist movement, the federation disappeared rather soon after the November 1924 meeting. The low interest of the Communist International in regional cooperation contributed strongly to its disappearance, though other factors were also involved. The parties had agreed during the foundation of the federation that the post of secretary would rotate. When it was entrusted in early 1925 to the Communist Party of Denmark, which had difficulties in taking care of its own issues, the federation in practice ended.

It took a couple of years before the Swedish communists, who were worried about the cooperation of the Nordic social democrats, suggested a revival of Scandinavian cooperation. They also had plans to found a new secretariat in Stockholm. This secretariat was meant as a service office which was supposed to give advice and information, not to make any binding decisions. ${ }^{4}$

\section{Scandinavian and Polish-Baltic secretariat 1926-35}

The secretariat, however, was not founded according to the intention of the Swedish communists. In March 1926 the Communist International decided to revamp its organization and create regional secretariats for guidance of the communist parties in va- 
rious regions. This decision implied an attempt at centralization as the secretariats were stationed in Moscow, not in various cities around the world (see e.g. Adibekov and Shakhnazarova 1996: 67-68).

Although it took until the end of 1927 before the Scandinavian secretariat was founded, the formation of regional secretariats had a fundamental effect on Nordic or Scandinavian cooperation. The Scandinavian federation had emphasized the Nordic character of the cooperation and tried to bring forth issues which were common to the whole region. The Scandinavian regional secretariat in Moscow tried to do the same but the perspective was that of Moscow. The secretariat was also in the habit of tackling the separate issues concerning each individual Scandinavian country; the agenda did not usually include common Nordic or Scandinavian issues. After all, the aim of the regional secretariat was to prevent cooperation between the Nordic communist parties rather than further it. Or at least the Comintern wanted to be in control (Saarela 2002a: 108).

The foundation of regional secretariats also led to the exclusion of the Finnish communists from Nordic cooperation. The activities of the Finnish communists in Stockholm from 1918 to 1920 were meant to compensate for the poor contacts with activists in Finland. The emigrant party also wanted to be in the vanguard of the world revolution and to be active everywhere.

As contacts with Finland improved and belief in an immediate world revolution subsided, SKP's interest in the Nordic or Scandinavian countries diminished, though they wanted to continue being included in any possible cooperative efforts. At the same time, they wanted a special position above the others. The leaders of the SKP considered themselves better communists than the Scandinavians because they had started an armed revolution and founded their communist party as early as August 1918. They also felt closer to the Bolsheviks since they lived in Soviet Russia. This feeling of superiority and representing the avant-garde was strengthened by the fact that the Communist International nominated Finnish communists to take care of various questions in 
Scandinavia and to instruct Scandinavian parties. Thus, the Finns regarded themselves as qualified to give advice to others but not to discuss their own matters with them (Saarela 1996: 67-72, 109-19; Saarela 2002a: 108-9; on Finnish communists and Scandinavian parties, see also Josephson 1976: 104-6, 114-16; Egge 1995: 66-70, 73-77; Björlin 1997: 204-6).

Although the Communist International nominated Finnish communists to direct the Scandinavians, it did not include Finland in Scandinavia. As early as summer 1922 the International informed the Finnish party that it would belong to the section of the Randstaaten (border states), which at that time was a loose Baltic-Balkan group. In summer 1926 the position of the SKP became more evident; it was included in the Polish-Baltic secretariat (On the SKP in the Polish-Baltic secretariat, see Saarela 2002a: 109-10).

The Communist International did not give reasons for this division, but there could be many explanations. First of all, the countries included had earlier belonged to the Russian Empire. The Bolsheviks had as early as the first decade of the twentieth century tried to unify the labour movements in these parts of the empire under the same organization. This had been rejected by the Finnish movement but accepted by the Polish, Latvian and Lithuanian parties (Kujala 1989: 160-67, 275-86). The PolishBaltic regional secretariat was a revival of this old idea.

The division was also quite clearly based on the security interests of the Soviet Union; it was worried about cooperation between its border states, which it saw as motivated by the aggressive aims of some of the great powers. This anxiety grew as Pilsudski seized power in Poland in 1926 (see e.g. Service 2005: 243, 256).

There could also be other reasons for the division; compared with the Scandinavian countries, Finland, Poland and the Baltic countries were agricultural economies which had been troubled by internal conflicts leading to armed confrontations. Their democracies also had deficiencies. The communist parties, whose prehistory included armed revolutions or coups, were, at least partly, prohibited in these countries, and their leaders resided in 
Moscow (see Raun 1987: 112-37; Kirby 1995: 298-301, 317-29; on confrontations, see Alapuro 1988: 231-43).

The leaders of the SKP did not comment on their inclusion in the Polish-Baltic secretariat, though contacts between the Finnish labour movement and those of the Baltic countries, and Poland in particular, were few before 1917. They did not increase with the foundation of the SKP, although some Finnish red refugees took part in the struggle against the Estonian Whites in 1919 and the SKP tried to learn something from the abortive coup of the Estonian communists in 1924 (Saarela 2002a: 110).

The separation between Finland and the other Nordic countries continued after the suppression of the regional secretariats in 1935. Their tasks were given to various secretariats named according to their leaders. Communist activities in the Scandinavian countries and Iceland were led by the German Wilhelm Florin; in Poland and in the Baltic countries and Finland by the Russian Mihail Moskvin, alias M. A. Trilisser, who was also a prominent figure in the Soviet security police NKVD. When he was arrested in 1938, these communist parties were left under the guidance of Klement Gottwald, a Czechoslovakian communist. Thus, it was a Comintern habit to make someone outside the Nordic countries responsible for Nordic issues. The representatives of the parties, however, participated in the work of the secretariats (on the personal secretariats, see e.g. Huber 1998: 50-52).

\section{Nordic communists in the organs of the Comintern}

Despite the institutional separation, it was possible for Nordic communists to cooperate in the various organs of the Communist International. Indeed, representatives from the four Nordic countries usually participated in the congresses and plena - Iceland was seldom represented (see e.g. Der zweite Kongress der Kommunist Internationale 1921[1920]: 780-88; Protokoll des III Kongresses der Kommunistischen Internationale 1921: 1068-71; Protokoll fünfter Kongress der Kommunistischen Internationale 
1924: 1054; Protokoll sechster Weltkongress der Kommunistischen Intemationale 1928: 569-70). Norwegian, Swedish and Finnish representatives also participated in the executive committee of the Communist International (Adibekov et al. 1997: 21, 38-40, 65-66, 95-96, 140-41, 182-84). There were, however, no recorded attempts to lobby for issues together. On some occasions, though, the Scandinavians defended each other against the criticism of the International (Josephson 1976: 183-85, 200-211).

The attempt to lobby together was obviously difficult since the Comintern not only discouraged such cooperation between the parties, but sought to interfere in the activities of the individual parties. In that respect the Scandinavian and Finnish parties were very different in the 1920s; Swedish and Norwegian questions were rather often on the agendas of the organs of the International, while Finnish questions were seldom taken up even though the Finnish movement was troubled by the same kind of problems as the Scandinavian parties (Saarela 2002a: 112-13; 2002b: 40-41). The reason for this was that the Finns were in a better position to look after their interests in another way. From the very beginning, Finnish communists living in Soviet Russia had close contacts with the Russian Communist Party and had learned to discuss their problems with the Russians. Even in cases where Finns contacted the Comintern to ask for advice, it was often the Russians who discussed the matter with the Finns.

The Finns were in a better position in another respect, too. First, they had their own man, Otto Ville Kuusinen, in the central organs of the International. He could dismiss the Finnish question or discuss it informally with other functionaries of the International. The other leaders of the SKP also lived in Soviet Russia, from 1918 to 1924 in Petersburg and later in Moscow, and had contacts with the Russians and the functionaries of the International. Members of the Scandinavian parties, on the other hand, resided only occasionally in Moscow.

Conditions in Finland did not allow as much room for communist publicity as in the Scandinavian countries. Therefore the Finnish movement did not hold discussions on its goals or policies. 
Doubts about the instructions of the International or the SKP leadership were seldom expressed in public, though the movement in Finland interpreted these instructions along the traditions of the Finnish labour movement and taking into consideration the conditions in the country. In the Scandinavian countries doubts and dissenting opinions were openly expressed and became the target of criticism by the International.

As there were never any foreign representatives of the Comintern in Finland, the Finns were able to filter messages; they could exaggerate their successes or difficulties. The fact that Finnish communists were active in two countries also contributed to the scant appearance of Finnish questions on the agenda of the Communist International. In a sense the SKP leadership took over the tasks of the International in directing the movement in Finland, and it was not necessary to discuss Finnish issues in the organs of the Comintern. The situation changed in 1929 as the Comintern started to constantly interfere in issues regarding the Finnish movement. Initially the internal disputes in Finland were the reason, but the ban on public activities gave even more reason. Thus, the SKP came under the tight control of the International and its Polish-Baltic secretariat and remained so until 1934 (Saarela 2002b: 41, 44-45).

\section{Norwegian-Russian-Finnish cooperation}

Issues of cooperation were generally defined by the Communist International, but the motives of the participants were not necessarily the same in this area. That was evident in the attempts to create cooperation between the Nordic and Russian trade unions in the latter half of the 1920s. These attempts took place without any formal discussion or decisions in the Comintern.

The trade union movement had also split along the lines of the division of the international labour movement in the early 1920s; the trade unions dominated by social democrats belonged to the International Trade Union Federation, better known as the Ams- 
terdam International, while the communists had founded the Red International of Labour Unions, usually called Profintern. This division made the international orientation of the trade unions problematic, especially in Finland where the Central Organization of Finnish Trade Unions (Suomen ammattijärjestö, SAJ) was dominated by those to the left of the social democrats. Although the SAJ decided to join Profintern, the decision was not carried out, the aim being to keep the trade unions united and not to give the authorities an excuse to suppress the SAJ. Thus the Finnish trade union movement remained outside the internationals. The Norwegian movement made the same kind of decision (Kettunen 1986: 163-73, 351-53, 356-65; Maurseth 1987: 378-83).

Therefore, the hope of creating a united trade union international lived on in both of these movements. As the trade unions of the Soviet Union and Great Britain formed an Anglo-Russian Joint Advisory Council in 1925, the Finnish and Norwegian movements regarded it as a basis for a new international and wanted to join. This, however, was rejected (Calhoun 1976: 154-56, 184, 200; Tosstorf 2004: 614-28).

Russian enthusiasm for creating contacts with those trade unions outside both internationals increased only after the collapse of the Anglo-Russian cooperation at the end of 1926 (Calhoun 1976: 359-71, 377-91; Tosstorf 2004: 630-31). Afraid of becoming isolated from the trade unions, the Russians started to discuss cooperation with the Nordic trade unions in early 1927 (Kettunen 1986: 454). ${ }^{5}$

The Norwegian and Finnish trade unions saw cooperation as a way to promote the formation of a new united trade union international and agreed on Norwegian-Russian-Finnish cooperation in Copenhagen in February 1928, although the formulations favoured the Russians and put the SAJ in jeopardy. They, however, began to hesitate as it became clear that the Swedish and Danish trade unions would sever relations with the Norwegians and Finns if the agreement was ratified. The ratification also caused disputes between the SKP leaders in Moscow and those in leading positions in the SAJ, and was one factor contributing to the divi- 
sion of the movement at the turn of 1929-30. Not even the proponents of the agreement, who had a majority in the SAJ in 1929, were willing to ratify it. The possible cooperation with the Russians, however, contributed to the dissolution of the Finnish trade union movement by the state authorities in 1930. In Norway the consequences of the agreement were not as fatal (Kettunen 1986: 455-58; Lorenz 1986: 192-94; Saarela 2002a: 110-12).

\section{The Communist International and the Nordic countries}

Although the Communist International preferred communist activity to follow the borders of a nation state instead of within a region, it did not attach great value to small nation states as it made its assessments on the international situation; it regarded small states as pawns in the game played by some of the great powers (Service 2005: 243). The Comintern emphasized instead the division of the world into two camps, and this division was especially underlined after the doctrine 'socialism in one country' was launched in the mid-1920s. Since the doctrine accepted the possibility of building socialism in the Soviet Union without a revolution in the more industrialized countries, it also strengthened formulations presenting the Soviet Union and the main imperialist countries as two different categories. The Comintern did not label the camps as clearly as the communists in the late 1940s and early 1950s; it did not, however, allow much room for neutrality (see McDermott and Agnew 1996: 50-52; for the 1940s and 1950s, see Spriano 1985: 296-300).

This was the basis for the stand taken by the Communist International and the Nordic communist parties towards the international situation in the early 1930s. The rise to power of the National Socialists in Germany did not change this stance, and there was a certain contradiction between the line of the Comintern and the orientation of the Soviet Union to collective peace treaties and appeals for peace in the international fora up to the 
launching of the popular front strategy at the seventh congress of the Comintern in the summer of 1935 (Haslam 1984: 54-59). Even though the new strategy called for cooperation with other political forces, the attitude towards regional cooperation of the states did not change; the proposals on Nordic cooperation made in the Nordic countries were rejected and regarded as a threat to the Soviet Union (Salmon 1997: 198-205).

There was, however, a notable change in this respect in 193738; the Communist International and the Scandinavian communist parties started arguing for Nordic cooperation. Now such cooperation was considered to be directed against Germany. Little by little the attitude even towards armed cooperation of the Nordic countries became positive, and the communist parties condemned the disapproving attitude of their governments. The Communist International and the Scandinavian parties were more outspoken on this question than the leadership of the Soviet Union, whose attitude to Nordic cooperation was vague, and it remained a central issue among the Scandinavian parties; the Norwegian Communist Party still spoke on its behalf in early 1939 (on the attitudes of the Communist International and the Scandinavian parties, Holtsmark 1992: 52-57).

Although the Scandinavian communist parties took a different stand in questions of security policy than the governments and the social democratic parties in these countries, they gained some respect as opponents of fascism and war. This image collapsed at the end of 1939. The Swedish Communist Party, in particular, strongly defended the non-aggression pact between the Soviet Union and Germany in August 1939, and the Soviet invasion of Finland later that year. These stands drove the party to isolation and to the brink of being banned. The same happened in Norway and Denmark (Hirdman 1974: 23-50; Halvorsen 1996: 19-20; Jacobsen 1996: 263-68). Thus, Swedish and Norwegian communists were more apt to accept the interpretations presented by the Soviet Union and the Communist International than to follow the example of the Finnish rank-and-file communists, many of whom condemned the Terijoki government, 'a people's govern- 
ment' formed of Finnish communists living in the Soviet Union, on the initiative of the Soviet leadership, and located on occupied Finnish territory. Many of the rank-and-file members also participated in the war against the Soviets (on the Finnish communists and the Terijoki government, see Rentola 1994: 166-80). This also indicates that it was very difficult for the Nordic communists to commit themselves as defenders of small states in a large international crisis.

\section{Conclusion}

To sum up, the cooperation of the young Nordic communist movements in the early 1920 s could be seen as a continuation of the traditions of the Nordic labour movements. The weakness of the parties and the reluctance of the Communist International to promote such cooperation contributed to its decline. The establishment of the regional secretariats in the International indicated an attempt to increase control over this cooperation and to separate the Finns from their Nordic peers.

Although the Comintern tried to control this cooperation between the Nordic movements, it was not always the initiator; protests and demonstrations against the repressions in Finland, for instance, were usually begun by the Scandinavian parties. There was also informal cooperation between the members of the movements, but the restrictions on dealings across the borders hindered its extension. The lack of knowledge of languages was for the Finnish rank-and-file communists an important factor preventing Nordic cooperation. Certain events, however, provided an incentive for the movements in the other countries (Saarela 2002a: 113-19).

The reluctance of the Communist International was an important reason for the insignificant cooperation between the Nordic communist movements. But it was also difficult to find common practical tasks; there was no common institution, no Nordic state or federation whose policies the movements could 
have opposed. The many similarities between the Scandinavian states could have offered opportunities for the communist parties to campaign together, but even that was difficult regarding questions on the power relations in the countries. The Scandinavian communist movements did not attempt such ventures, but let the Communist International steer cooperation on questions concerning their international orientation.

Although cooperation between the Nordic communists was not of great importance, more studies on cooperation and contacts between the various communist parties would be useful. It would provide greater opportunity to assess the character, policies and internationalism of the international communist movement.

\section{Notes}

1 Rossiiskii gosudarstvennyi arkhiv sotsialno-politicheskii istorii (RGASPI), fond (f.) 510, opis (op.) 1, delo (d.) 1, Rapport über Tätigkeit des Skandinavischen Komitees der III Intemationale, 16 June 1920; Allan Wallenius, Das Skandinavischen Komitee der Komintern, 12 August 1921; Allan Wallenius to comrade G. Zinovieff 2 and 19 May and 4 June 1920.

2 RGASPI, f. 510, op. 1, d. 3, Protokoll fort vid konferens mellan Sverges och Danmarks kommunistiska partier, Norske Arbetarepartiet samt Finlands kommunistiska och socialistiska arbetarepartier den 1 och 2 april 1922.

3 On the Scandinavian federation, RGASPI, f 510, op. 1, d. 15, Skandinavian maitten kommunistipuolueitten 20-22 p. tammik. pitämän konferenssin pöytäkirja; Tätigkeitsbericht der Skandinavischen Föderation 2 June 1924 Moskau; Zur Gewerkschaftslage in Skandinavien; Informationsbrief über Skandinavien 25 December 1924 Moskau; Kurzer schematische Bericht über die Tätigkeit des Skandina- 
vischen Ländersekretariats beim EKKI [Executive Committee of the Communist International] von 4.10.1927 bis 4.7.1928.

4 RGASPI, f 510, op. 1, d. 12, Resolution Über das skandinavische Sekretariat; d. 13, Kurzer schematische Bericht über die Tätigkeit des Skandinavischen Ländersekretariats beim EKKI von 4.10.1927 bis 4.7.1928.

5 On the attitudes of the Soviets e.g., RGASPI, f. 495, op. 3, d. 8, 0. Manuilski an das politische Sekretariat des EKKI, Genossen Buharin, Kuusinen, Piatnitzki, Losovski, 30 Januar 1927.

\section{References}

Adibekov, G. and Shakhnazarova, E. (1996) 'Reconstructions of the Comintern Organizational Structure,', in M. Narinsky and J. Rojahn (eds) Centre and Periphery. The History of the Comintern in the Light of New Documents, Amsterdam: IISG, 65-73.

Adibekov, G. M., Schahnazarova, E. N. and Shirinja, K. K. (1997) Organizatsionnaja struktura Kominterna 1919-1943, Moscow: Rosspen.

Alapuro, R. (1988) State and revolution in Finland, Berkeley, Los Angeles and London: University of California Press.

Bloch-Poulsen, J. and Thing, M. (1979) Danmarks kommunistiske parti 1918-1941, Viborg: Politisk revy.

Björlin, L. (1997) 'För svensk arbetarklass eller sovjetisk utrikespolitik? Den kommunistiska rörelsen i Sverige och förbindelserna med Moskva 1920-70', in S. Jungar and B. Jensen (eds) Sovjetunion och Norden - konflikt, kontakt, influenser, Helsingfors: FHS.

Bolin, J. (2004) Parti av ny typ? Skapandet av ett svenskt kommunistiskt parti 1917-1933, Stockholm: Acta universitatis Stockholmiensis. Stockholm Studies in History.

Calhoun, D. F. (1976) The United Front. The TUC and the Russians 1923-1928, Cambridge: Cambridge University Press. 
Der zweite Kongress der Kommunist. Internationale. Protokoll der Verhandlungen vom 19. Juli im Petrograd und vom 23. Juli bis 7. August 1920 in Moskau (1921), Hamburg: Carl Hoym Nachf.

Egge, Å. (1995) Komintern og krisen i Det norske Arbeiderparti, Oslo: Universitetsforlaget.

Elvander, N. (1980) Nordisk arbetarrörelse, Stockholm: LiberFörlag.

Fridriksson, T. (1990) Den gyldne flue. De skandinaviske socialdemokratiers relationer til den islandske arbejderbevaegelsen 1916-1956. Internationalisme eller inblanding? Århus: SFAH.

Grass, M. (1974) 'Arbetarskandinavism 1912-20: Komittén för skandinaviska arbetarrörelsens samarbete, några aspekter', in Årbog för arbejderbevaegelsens historie 4, Copenhagen: SFAH.

Halvorsen, T. (1996) Mellom Moskva og Berlin. Norges Kommunistiske Parti under ikke-angrepspakten mellom Sovjet-Unionen og Tyskland 23. august 1939-22. juni 1941, Oslo: Falken Forlag.

Haslam, J. (1984) The Soviet Union and the Struggle for Collective Security in Europe, 1933-39, New York: St Martin's Press.

Hirdman, Y. (1974) Sverges Kommunistiska Parti 1939-1945, Stockholm: Allmänna Förlaget.

Hjartarsson, S. F. (1989) Kampen om fackföreningsrörelsen. Ideologi och politiskt aktivitet på Island 1920-1938, Uppsala: Acta Universitatis Upsaliensis.

Holtsmark, S. G. (1992) Enemy springboard or benevolent buffer? Soviet attitudes to Nordic cooperation, 1920-1955, Oslo: IFS.

Huber, P. (1998) 'Structure of the Moscow Apparatus of the Comintern and Decision-making', in T. Rees and A. Thorpe (eds) International Communism and the Communist International 1919-43, Manchester and New York: Manchester University Press.

Jacobsen, K. (1996 [1993]) Aksel Larsen. En politisk biografi, Copenhagen: Vindrose.

Josephson, E. F. (1976) SKP och Komintern 1921-1924. Motsättningarna inom Sveriges Kommunistiska Parti och dess relationerna till den Kommunistiska internationalen, Motala: Acta Universitatis Upsaliensis.

Kan, A. (2005) Hemmabolsjevikerna. Den svenska socialdemokratin, ryska bolsjeviker och mensjeviker under världskriget och revolutionsåren 1914-1920, Falun: Carlsson Bokförlag. 
Kangaspuro, M. (2000) Neuvosto-Karjalan taistelu itsehallinnosta. Nationalismi ja suomalaiset punaiset Neuvostoliiton vallankäytössä 1920-1939, Helsinki: SKS.

Kettunen, P. (1986) Poliittinen liike ja sosiaalinen kollektiivisuus. Tutkimus sosialidemokratiasta ja ammattiyhdistysliikkeestä Suomessa 1918-1930, Jyväskylä: SHS.

Kirby, D. (1986) War, Peace and Revolution. International Socialism at the Crossroads 1914-1918, Aldershot: Gower.

Kirby, D. (1995) The Baltic World 1772-1993. Europe's Northern Periphery in an Age of Change, London and New York: Longman.

Kujala, A. (1989) Vallankumous ja kansallinen itsemääräämisoikeus. Venäjän sosialistiset puolueet ja suomalainen radikalismi vuosisadan alussa, Jyväskylä: SHS.

Loftsson, E. (1981) Island i NATO - partierna och förvarsfrågan, Göteborg: Göteborgs universitet.

Lorenz, E. (1978) Norwegische Arbeiterbewegung und Kommunistische Internationale 1919-1930. Untersuchung zur Politik der norwegischen Sektion der Kommurzistischen Internationale, Oslo: Pax Förlag.

Lorenz, E. (1986) 'Norwegens Gewerkschaften zwischen Amsterdam und Moskau: Versuche eines Brückenbaus', in Internationale Tagung der Historiker der Arbeiterbewegung. 16. Linzer Konferenz, Vienna: Europa-Verlag.

Maurseth, P. (1987) Gjennom kriser till makt (1920-1935), Arbeiderbevegelsens historie i Norge 3, Oslo: Tiden Norsk Forlag.

McDermott, K. and Agnew, J. (1996) The Comintern. A History of International Communism from Lenin to Stalin, London: Macmillan Press.

Protokoll des III. Kongresses der Kommunistischen Internationale (Moskau, 22. Juni bis 12. Juli 1921) (1921), Hamburg: Verlag der Kommunistischen Intemationale.

Protokoll fünfter Kongress der Kommunistischen Internationale. Band II (1924), Hamburg: Verlag Carl Hoym Nachf.

Protokoll sechster Weltkongress der Kommunistischen Internationale. Moskau, 17. Juli - 1. September 1928. Dritter Band (1928), Hamburg/ Berlin: Verlag Carl Hoym Nachf.

Raun, T. U. (1987) Estonia and the Estonians, Stanford CA: Hoover Institution Press. 
Rentola, K. (1994) Kenen joukoissa seisot? Suomalainen kommunismi ja sota 1937-1945, Juva: WSOY

Saarela, T. (1996) Suomalaisen kommunismin synty 1918-1923, Tampere: KSL.

Saarela, T. (2002a) 'Den finska, skandinaviska och nordiska kommunismen på 1920-talet', in P. Kettunen (ed.) Lokalt och internationellt. Dimensioner $i$ den nordiska arbetarrörelsen och arbetarkulturen, Tammerfors: Sällskapet för forskning i arbetarhistoria i Finland, 104-28.

Saarela, T. (2002) 'Kommunistinen internationaali ja suomalainen kommunismi 1919-1935', in N. Lebedeva, K. Rentola and T. Saarela (eds) 'Kallis toveri Stalin!'. Komintern ja Suomi, Helsinki: Edita, 9-62.

Salmon, P (1997) Scandinavia and the Great Powers 1890-1940, Cambridge: Cambridge University Press.

Schmidt, W (1996) Kommunismens rötter i första världskrigets historiska rum. En studie kring arbetarrörelsens historiska misslyckande, Stockholm: Symposium.

Service, R. (2005 [2004]) Stalin. A Biography, London: Pan Books.

Soikkanen, H. (1975) Kohti kansanvaltaa 1. 1899-1937, Vaasa: SDP

Spriano, P. (1985) Stalin and the European Communists, London: Verso.

Svensson, L. (1986) 'Arbetarkongresserna i Norden under 100 år', in De nordiska arbetarkongresserna under 100 år. Arbetarrörelsens framväxt och utveckling $i$ de nordiska länderna, Jönköping: ARAB, $17-116$.

Tosstorf, R. (2004) Profintern: Die Rote Gewerkschaftsinternationale 1920-1937, Paderbom-Munich-Vienna-Zürich: Ferdinand Schöningh.

Upton, A. F. (1980) The Finnish Revolution 1917-1918, Minneapolis: University of Minnesota Press. 


\section{American impact on Finnish communism in the 1920s}

Between 1870 and 1919, 329, 000 Finnish workingmen and women emigrated from Finland to America. Many of these emigrants became members and supporters of the Finnish labour movement in America and some brought with them principles and working methods of the labour movement in Finland - if they had experience of it. On the other hand they learned new ideas and working methods in the labour movement in America and when returning to Finland, carried those experiences with them. (Kero 1996, 54-56, 255). Of the well-known Finnish labour leaders, for instance, Oskari Tokoi, Taavi Tainio and Yrjö Sirola spent some years in America. (Soikkanen 1961, 36, 167; Salomaa 1966, 149-169).

This lively interaction between the labour movements in Finland and America decreased during World War I. The emigration from Finland to America revived in the 1920s (Kero 1996, 54, 58 ), but movement from one labour movement to another did not occur as smoothly as before the First World War. In Finland there was need for experienced and capable functionaries in the labour movement as the workers' side lost 27, 000 persons during the abortive revolution and its aftermath in 1918, and 6, 000 to 10, 000 escaped to Soviet Russia. ${ }^{1}$ The conditions in the country did not inveigle those working in America into returning to Finland.

The division of the labour movement also made interaction more complicated. The Communist International, founded in March 1919, wanted to be an international world party and the 
centre of all communist activities. It demanded its member parties to follow, strictly, its decisions and instructions in their policies. ${ }^{2}$ It was also reluctant to promote co-operation between national communist parties, and wanted to have a strict control of contacts and impulses between them. (Saarela 2009b, 244). There was, however, interaction between communism in Finland and the Finnish labour movement in America. This article touches those contacts and impulses and the impact of American Finns on Finnish communism in the 1920s.

\section{Finnish communism}

Communism in Finland was a product of movements that occurred in both Finland and Soviet Russia. Commitment to both countries was an inherent characteristic of the movement. ${ }^{3}$ As the Civil War fought after the independence of Finland from January to May 1918, ended in the defeat of the Reds, most of the leaders and functionaries of the revolutionary government escaped to Soviet Russia. There they came to the conclusion that the Finnish revolution had failed because they had stayed within the boundaries of bourgeois democracy. In order to get rid of this shortcoming, the red refugees founded the Finnish Communist Party (from 1920, the Communist Party of Finland) (SKP) in Moscow in August 1918. The new party wanted to abandon all the methods of the Finnish labour movement. It abandoned working within the parliament, trade unions and co-operative movement, and propagated armed revolution and the establishment of the iron hard dictatorship of the proletariat. The SKP was forbidden and had to work underground in Finland.

In Finland, Finnish communism began in the summer of 1919 as those dissatisfied with the politics of the re-founded Social Democratic Party (SDP) started to associate. These groups felt that the new leaders of the SDP had forsaken the strict line of the class struggle of the pre-Civil War labour movement, as they had condemned the attempt to take the power, rejected extra-parlia- 
mentary actions and given priority to the work in parliament and municipal councils and wanted to co-operate with centre parties. After the failed attempt to conquer the majority in the party congress in December 1919, these groups founded the Socialist Workers' Party of Finland (SSTP) in May 1920.

The SSTP got nearly 15 per cent of the votes in the parliamentary elections in 1922 and 27 seats out of 200. The supporters of the SSTP also had a distinct majority in the Finnish trade union movement (the SAJ), and most of the important unions. Thus the SSTP worked in the traditional fields of the Finnish labour movement, however all activities of the party were forbidden and its central and local leadership and members of the parliament were imprisoned in August 1923.

After the ban of the SSTP, which was consolidated by the court in 1924 and 1925, there were thoughts of founding a new party but Finnish communism was, however, organized in various local workers' associations which tried to keep up national and regional co-operation on the basis of Socialist workers' and smallholders' electoral organisations (STPV). This loose organization achieved 10 to 13 per cent of the votes and won 18 to 23 seats in 19241929. In the summer of 1930, all the public activities of Finnish communism were, however, forbidden, and its representatives in the parliament and municipal councils were expelled. It was only in autumn 1944 that the supporters of Finnish communism could properly participate in the political life of Finland.

Although the birth of the two branches of Finnish communism demonstrated different ideas on the character and tasks of the revolutionary labour movement, the representatives of the SKP and those in Finland were in contact in the summer of 1919 and worked together very closely from autumn 1920. Some of the leaders of the SSTP and STPV belonged to the Finnish Bureau, the main body of the SKP in Finland, and some of the Finnish activists participated in the conferences of the SKP in Soviet Russia/the Soviet Union. The SKP financially supported SSTP and STPV's election campaigns and some of their newspapers. 
The two branches of Finnish communism were, however, living in quite different conditions which had effects on their political line. Those in Soviet Russia/the Soviet Union were captured by the idea of the world revolution and found their salvation in the Bolshevik ideas. In a country where communists were in power, it was easier to follow the instructions of the Bolsheviks and the Communist International than in Finland, where the movement tried to overcome the losses of the Civil War and to fight for its existence. Thus the agendas of the Finnish and Soviet branches of Finnish communism were quite different.

As the Finnish branch of the movement was under a constant threat of being forbidden, questions concerning political rights and liberties of the workers and the labour movement were very important. Closely connected with rights and liberties were the demands of the abolition of the coercive apparatus of the state. These were main paroles in the election campaigns and demonstrations during the whole decade. The questions concerning the ideological institutions - religion, church and school - were also important for the movement. The concern for the economic and social situation of the workers put forth proposals of various social reforms, especially those concerning workers' insurances. The forbiddance of the SSTP and other organizations made the movement in Finland continuously ponder the organizational questions and movement's relation to social democrats.

Organizational questions and relation to social democrats were also important for the SKP leadership, as for the whole international communist movement. The international aspect was more obvious in the questions concerning the international situation and the position of Soviet Russia/the Soviet Union within the international community. That was the perspective from which the Soviet branch of Finnish communism studied Finland and its relation to other nations, especially to imperialist powers. 


\section{American Finnish support and solidarity towards Finnish communism}

While Finnish communism was formed as a mixture of the traditions of the Finnish labour movement and the new communist movement and doctrine inspired by the Russian Bolsheviks, the Finnish labour movement in America also had a great influence on the formation of Finnish communism. In 1918, after the disastrous Civil War in Finland, the American Finns had started a money-raising campaign in order to help the re-birth of the labour movement in Finland. Each local was supposed to contribute to the campaign. With the division of the labour movement, the question arose as to who in Finland should receive the money. The radicals wanted the money to be sent to the 'real representatives of the Finnish working class', while the majority of the eastern associations wanted the Social Democratic Party of Finland to get the money. The radicals had, however, the majority at the Chicago convention in 1919, and the decision was made to send the money to the radical faction of Finnish labour movement. The decision caused disagreement among the Finnish American associations, and at the beginning of 1920 it was decided to organise a general vote on the matter. Before the vote was taken, news about the foundation of the Socialist Workers' Party of Finland reached America and the leadership of the Finnish Federation sent the money to the newly founded party. (Kostiainen 1978, 99-100).

Although the SKP also sent money to Finland, the American money - about 55000 dollars - had a significant contribution to the formation of the SSTP and the whole Finnish branch of Finnish communism. Most of the money was obviously used in the creation of the publishing company Työ and Suomen Työmies, the main organ of the SSTP in Helsinki. The American money gave basis for a certain amount of independence at the moment when the SKP was willing to give money to the SSTP only on the condition the SSTP would obey its instructions and platform. (Saarela 1996, 197-198). 
Later on the financial support of Finnish communism was dominated by the money coming from the Russian Communist Party and the Communist International (Saarela 1998). In some instances, the financial support from the Finns in the United States and Canada was significant; during the parliamentary election in 1927, for instance, one quarter of the money the STPV spent in elections came from America. (Saarela 1998, 284-285). The newspapers occasionally also received smaller sums of money from Finns in America (Saarela 2008a, 130).

The Finnish labour movement in America was also, in other respects, important for Finnish communism in Finland. As Finnish communism was a target for the authorities' persecution in the 1920s, the Finnish labour associations in America, along with the Scandinavian labour movement, sent their expressions of solidarity to the Finnish comrades and of disapproval and condemnation to the Finnish authorities during large imprisonments and trials. (Saarela 2009c, 127-128). There were large demonstrations in many American cities especially in 1935, during the trial of Toivo Antikainen, a member of the leadership of the SKP who was accused of murdering a man in Karelia in 1922 (Saarela 2009a, 34-35). In the expressions of international solidarity Finnish communism was rather a receiving partner, but in August 1927, communist organizations in Finland expressed their condemnations against the execution of Nicola Sacco and Bartolomeo Vanzetti and the Finnish trade union movement started a boycott on American products. ${ }^{4}$

Despite the difficulties of publishing communist material in Finland from 1923 onwards, Finnish communists did not actively try to publish books in America in order to get communist material in Finland. They found it easier to publish communist material in the Finnish language in Soviet Russia, despite the occasional shortage of proper paper. Thus many of the basic works of communism - Lenin's State and Revolution, Imperialism as the Highest State of Capitalism, Proletarian Revolution and the Renegade Kautsky, Left-wing Communism: an Infantile Disorder, Bukharin's and Preobrazhensky's The ABC of Communism, Trot- 
sky's Terrorism and Communism as well as the most important decisions of the second and third congresses of the Communist International were already published in Finnish in Soviet Russia. State and Revolution and Left-wing Communism, The ABC of Communism and Terrorism and Communism were published in Finland in the early 1920s. It was also possible to publish Stalin's Problems of Leninism in Finland in 1926. The fact that socialist literature was often confiscated by the Finnish custom officials also prevented import of literature from America to Finland. (Saarela 1996, 199-200, 488-490; Saarela 2008a, 575-576).

It was only in 1927-28 that the leadership of the SKP tried to take advantage of the publishing opportunities of the Finnish labour movement in America. Finnish communists in the Soviet Union had, as early as 1925, founded a research club to study the events on various fronts during the Finnish Civil War. This club launched an idea of editing a large volume to honour the 10th anniversary of the class war in Finland. The SKP did not believe that it would be possible to publish such a book in Finland, and therefore the SKP asked the Finnish labour movement in America about potentially publishing the book. The book, Suomen luokkasota, which consisted of articles about the battles of the war, white terror and prison camps, came out in Wiscon$\sin$ at the end of January 1928. The intention was to smuggle the book from Sweden to Finland. The book was, however, late for the exact anniversary. Getting the book into Finland was further delayed because of the arrest of the underground functionaries of the SKP during the spring of 1928. Thus Suomen luokkasota did not contribute much to how the Finnish communist remembered the events of the abortive revolution and its aftermath in Finland in 1928. (Saarela 2008a, 562-564). The interest in taking advantage of the publishing opportunities of Finnish labour movement in America did not increase after the ban of the public activities of Finnish communism in Finland in the summer of 1930.

The solidarity between the Finnish labour movement in America and communism in Finland was one-way solidarity. This was mainly due to the difficult conditions in Finland. The interaction 
between the Finnish labour movement in America and Finnish communism was, however, not limited to instances of financial support or expressions of solidarity. There were also occasions when individuals with involvement in the Finnish labour movement in America came to Finland or to Soviet Russia/the Soviet Union.

\section{American Finns within Finnish communism}

Leo Laukki was perhaps the most prominent of Finns with great experience in the Finnish labour movement in America who started to work for Finnish communists in Soviet Russia or in Finland in the early 1920s. Laukki, a former officer of the Russian imperial army, had worked in co-operation with the Bolsheviks in 1905-06 and escaped from Finland in 1907. Thereafter he had worked as a newspaperman and instructor in the Finnish labour movement in America. He had advocated first the ideas of the Industrial Workers of the World (IWW) and then those of communism. Under the threat of being sentenced to prison, he escaped from the United States to Soviet Russia in the spring of 1921. ${ }^{5} \mathrm{He}$ arrived in Soviet Russia at a moment when the leadership of the SKP was divided into two fractions and in order to bring fresh blood into the SKP leadership, Laukki was elected as the member of the central committee and secretary of the SKP in its third congress in August 1921. Laukki was also sent to Finland, where he worked as a member of the Finnish Bureau of the SKP as an underground adviser of Finnish communism from September 1922 to April 1923. (Saarela 1996, 239-240, 322-325).

Niilo Wälläri (born Välläri) who, after three years at sea, worked in the United States from 1916 to 1920 and became acquainted with the ideas of the IWW, returned to Finland in November 1920. Despite his youth, Wälläri was to become an important figure in the Finnish branch of Finnish communism. Before starting as a district secretary of the SSTP in Uusimaa in February 1921, Wälläri attended political courses organized 
by the SKP in the neighbourhood of Petrograd. A year later, at the end of January 1922, he became chairman of the SSTP and moved from that position to the secretary of the party in May 1923. Wälläri was arrested in the beginning of August the same year and condemned to imprisonment for preparation of high treason. (Savolainen 1978, 23-111; Saarela 2008a, 201, 328, 354, 501).

Toivo Vuorela, who had moved to America in 1913 and worked there as a carpenter and as an organizer for the Finnish Socialist Federation and the Communist Party of America, returned to Finland via Soviet Russia in September 1922. In Finland he was engaged as a propagandist of the SSTP in December 1922 and from April 1923 as the party's district secretary in Kuopio. Vuorela was also arrested in the beginning of August 1923, but set free to wait for the beginning of his tria $1 .^{6}$

The ban of the SSTP and the arrests of the members of the SSTP's national and local leadership and its members of parliament in August 1923 made the Finns in America more important. Even the SKP wanted more activists in Finland and, in order to increase their numbers, invited two persons from the USA. Its intentions were to harness them in the guidance of public mass movement and to invite a third person later to help in the newspaper work. This plan of three individuals was, however, reduced to one. Severi Alanne, the man who arrived in Finland during the mid-November 1923 seemed to he very appropriate; as early as 1905-07 he had wanted to connect the Finnish labour movement with the struggle against autocratism in Russia, had helped the military organization of the Russian Social Democratic Labour Party (VSDTP) and had attempted to create a secret organization in order to promote these goals. Alanne was, however, forced to go into exile in America in 1907, where he had been active foremost in the cooperative movement, but also as a newspaperman and in editing the Finnish-English-Dictionary which came out in 1919. In addition, he had spoken for the affiliation of the American Socialist Party to the Communist International. (Saarela 2008a, 46). ${ }^{7}$ 


\section{Leo Laukki and the union of workers and ploughing}

men

The ban of the SSTP forced Finnish communists to question effective organizational forms. Those with American backgrounds presented their thoughts about the future organizational forms of Finnish communism.

Leo Laukki was among those who had an opinion of the new organization in Finland. In the plenum of the SKP in late August 1923, Laukki proposed the formation of the union of Finnish workers and ploughing men, which would unite the industrial workers and the toilers of the countryside and fight for their interests. Laukki was for an organisation without strict conditions for admission; all the industrial and farm workers' associations willing to accept its principals were welcome. While Laukki's proposal corresponded to the traditions of the Finnish labour movement, its roots lay with the Federated Farmer-Labor Party created in the United States in the summer of 1923. (Saarela 2008a, 304-305). ${ }^{8}$

Although all the participants were unanimous about the need to keep peasants apart from the ideological and political influence of the bourgeoisie and to abolish distrust between workers and working peasants, Laukki's proposal did not become the policy of the SKP. Otto Ville Kuusinen, a secretary of the Communist International, had considered promotion of the left opposition in the Agrarian Union and the formation of the union for the independent working peasants and agrarian labourers important in the beginning of August 1923. This union would fight against capitalism with the industrial proletariat. Despite its contradiction of the traditions of the Finnish labour movement, Kuusinen's proposal became the main line for the SKP policy in the 1920s. It also presented the idea of the union between the proletariat and peasants in a more mechanical way than Laukki's proposal. (Saarela 2008a, 305-306).

Kuusinen's ideas were based on the discussions in the Communist International about the co-operation between workers and peasants. The expectations of an immediate revolution in Germa- 
ny also shaped Kuusinen's thoughts; in front of a new revolution it was important not to repeat old mistakes - to let the peasants join the bourgeoisie as had, according to the SKP, happened in Finland in 1918. As early as 1910, with the influx of members from rural areas, Kuusinen began to question how to preserve the social democratic character of the party (Peltonen 1992, 255256). Preserving or creating an orthodox attitude was considered even more important in the communist movement.

\section{Severi Alanne and the independent workers' party}

In Finland the possibilities for the formation of a new organization were regarded as more favourable after the parliamentary election in February 1924, as the authorities had not prevented the electoral campaign. The campaign also brought out the defects of the organization at the district level. The legal process concerning the SSTP was, however, not finished, and supporters in many places wanted to wait for its outcome. There was no need for new organizational forms in towns and villages where the workers' associations could continue their activities. (Saarela 2008a, 64-65). Thus the discussion on the new organizational forms remained mainly in private spheres. The ideas presented by the functionaries of the SKP, like Severi Alanne, brought out different options and a different emphasis on partners, which perhaps reflected different backgrounds and experiences during the later years.

Alanne wanted to improve the possibilities of Finnish communism to act but also to prevent the social democrats from taking advantage of the situation. ${ }^{9}$ According to Alanne, the situation had deteriorated because of the inactivity of the SKP - it had not done anything to prevent the labour associations which had belonged to the SSTP from joining the SDP. In his opinion, the inactivity only encouraged social democrats. Alanne tried to frighten the SKP leadership by saying that those belonging to the 
communist right would found a new party if the SKP would not do anything.

Alanne himself proposed that, after their arrival in Helsinki, the future members of parliament take measures for the foundation of an independent workers' party by summoning the meeting of its representatives in May 1924. According to him the new party would also need a daily newspaper in Helsinki. Alanne also outlined some general principles for the new party. He believed the party should announce in its platform that it wanted to unite the fragmented workers' groups into a party for class struggle. The new party should also explain that it would not join any international organization but would, however, present its solidarity with Soviet Russia. The party should also urge workers in the SDP to join it and to let the SDP leaders to keep the SDP.

In order to promote that goal Alanne recommended helping the left in the SDP. It would be important that the SKP cease branding the 'centrists' but would try to bring them closer to the communists. Alanne proposed that the SKP give financial support to the newspaper as planned by the SDP-left in Helsinki. Alanne believed that through the newspaper it would be possible to solidify the SDP-left and isolate it from the party leadership. After more thorough consideration, Alanne changed his mind and thought that the 'centrists' would not dare to leave the SDP if the new party would be founded without hearing their opinions. Without the SDP-left the new party would look too 'communist' and its creation would obviously lead to actions by the authorities. Thus Alanne believed the 'centrists' should have the initiative or at least a leading position in the founding of a new party. Before that it would be good to provoke the SDP leadership against the 'centrists'.

Jaakko Kivi and Jalmari Salminen, who both had more experience with the leftist movement in Finland, supported the creation of a new party as soon as possible. Jaakko Kivi, the first chairman of the SSTP from summer 1920 to December 1920 and later the party's local functionary in middle-Finland, had escaped arrest in August 1923 and started to work as an underground member 
of the SKP leadership in Finland in the autumn of 1923. Jalmari Salminen had followed Kivi as the chairman of the SSTP in December 1920, but in order to avoid arrest, had to go underground and escape to Soviet Russia in January 1922. In the spring of 1923 he, however, returned to Finland in order to work as a member of the SKP leadership in Finland. (Saarela 1996, 165, 318-319, 328-329; Saarela 2008a, 45, 150).

Kivi and Salminen did not agree with Alanne on the composition of the new party and denounced the participation of left social democrats. (Saarela 2008a, 66-67) According to them, Finnish communism could not strengthen its position by planning a new party with the left in the SDP. They did not believe that the creation of a new party would split the SDP; the 'centre social democrats' would not dare to do anything, when the new party would be branded as communist and Moscow-led in publicity. They were also afraid that the SKP would not be able to guide the new party in the discussions with the SDP-left about the platform or procedures. They believed there would be a danger that the 'Noskes' would capture the organization, if it were persecuted. That would reduce the influence of communism on the masses. Kivi admitted that the participation of the 'centrists' would calm the suspicion of the authorities but despite that he did not want to entangle them in the new party.

Jalmari Salminen did not like the idea of an independent workers' party because that would indicate independence from communists, and that independence had been too large in the SSTP. Salminen thought that the leadership of the trade union movement longed for an independent workers' party but believed that the workers supporting class struggle would not be appealed for independence.

Salminen and Kivi had different opinions on how the new party should be founded. Kivi wished the foundation to take place quickly and suggested that the newly elected parliamentary group would take the initiative. Both Kivi and Salminen wanted to get more backing for the party and suggested the creation of new workers' local associations around the country. In order to con- 
nect the creation of a new party and the co-operation with the smallholders, Salminen suggested that a national smallholders' conference should be held during the spring of 1924. That conference would discuss the problems of the smallholders and the need for a real workers' and smallholders' party, as well as make a decision on the co-operation between workers and smallholders. At the same time workers' local associations would make decisions about the creation of a new party. A meeting of delegates from the workers' local associations would be summoned up later and a new workers' and smallholders' party would be founded. Salminen believed that the new party would above all be a party of the ex-members of the SSTP but he figured that there would be a significant number of smallholder members.

Kivi and Salminen were right that Alanne was too trusting about the intentions of the leftists in the SDP. Rather than becoming part of a 'communist' party, they wanted members of the SSTP to join the SDP in order to strengthen their position within that party. This was evident in discussions that took place in December 1923 and even more evident in proposals to convince hundreds of ex-SSTP members to join Toveriseura, a social democratic association in Helsinki. Further evidence lies in the suggestion to appeal for economic support for the newspaper in Helsinki and in the reassurances that the left would conquer the majority in the next party congress. The SDP left's wish to discuss the co-operation with the 'most sensible communists' indicated an attempt to get them separated from the main members of the SSTP. (Saarela 2008a, 67).

Severi Alanne and the social democrats

Although Alanne presented ideas about a re-organization of Finnish communism in Finland, organizing public communist activities was not his main task. Soon after his arrival in Finland he joined Toveriseura at the instruction of the Communist International to the SKP; according to them, 'conscious elements' 
should secretly enter the Social Democratic Party and support its left wing. Alanne was supposed to get assistance from the new members of the same association. After being deported from the United States to Soviet Russia in 1922, William Tanner, a former prominent member of the Industrial Workers of the World, turned to communism and joined Alanne in 1924.(Saarela 2008a, 180-181). ${ }^{10}$

Despite his colourful and suspicious past, Severi Alanne was given a warm welcome in Toveriseura; he was elected as its vice president at the annual meeting. Alanne was also able to speak in the events organized by the association. In these speeches he attempted to test the boundaries of the SDP. Those, however, proved to be narrow, as some old social democrats started to question whether Alanne was a communist. Alanne's status as a communist was also suspected by the SDP leadership, which demanded the association explain Alanne's true affiliations. Alanne had to explain himself to the Detective Central Police - political police that had been created to keep an eye on the reds. He told them that he could be a left socialist in America and remain active in the Social Democratic Party in Finland without changing his opinions.

This was not accepted and suspicions about the character of those affiliated in Toveriseura did not cease. An example of this suspicion is evident from the attitude towards William Tanner's speech at the meeting of Helsinki metal workers. His claim that the behaviour of the Second International had been wrong during the break out of the First World War raised Suomen Sosialidemokraatti, the main organ of the SDP, to ask whether there were communist cells in Toveriseura. Tanner eventually withdrew from the association. Enthusiasm towards crossing borders within the labour movement was not prominent in other respects, for the leadership of Toveriseura did not consider it appropriate that Alanne would speak in the May-Day celebration of the local trade unions.

These events indicated the end of Alanne's attempts to have a 'conspirational' influence in Toveriseura. Alanne left Toveriseura 
and Finland by the end of May. The willingness of the SKP to let Alanne go, after half a year in Helsinki, proved that the SKP leadership or the Communist International, influenced by the ideas of the SKP leadership, had not properly thought out the task they had presented. But it also proved that the attitude of the International and the leadership of the SKP towards the social democrats had changed dramatically during the spring of $1924 .{ }^{11}$

\section{Niilo Wälläri and large associations}

On the basis of Laukki and Alanne's proposals, the American impact on Finnish communism appeared rather insignificant and of short duration. These proposals, however, corresponded with the organizational traditions of the Finnish labour movement. Those traditions were strong also within Finnish communism in Finland. The result of these proposals was, however, not a new party; the SKP leadership was not satisfied with the independence of the SSTP and branded the idea of a new party as 'right-wing deviation' during the spring of 1925. Those in Finland considered the creation of a new party dangerous, particularly after the court decisions on the SSTP case. Thus the result was a looser Socialist workers' and smallholders' electoral organization which appealed to both urban and rural workers and began to correspond with the Social Democratic Party-left about Finnish political life. (Saarela 2008a, 70-80).

In that sense the organization was closer to Laukki's than Kuusinen's proposal. The SKP leadership did try to create an independent peasant party but managed to create contacts only with a small opposition to the Agrarian Party within the Viipuri district. The financial support of the SKP did help in the establishment of a newspaper for that opposition group but the emergence of an independent party and to gain a following were not as successful. Finnish communists did not participate in this campaign but rather founded own workers' and smallholders' associations. (Lackman 1985, 107-139; Saarela 2008a, 331-339, 346-347). 
Not even Santeri Mäkelä, the most prominent peasant agitator of Finnish communism in the mid-1920s, followed the SKP line, although, while living in the Soviet Union, he sent articles to Finnish communist newspapers between 1924 and 1926. Those articles, titled "Peasant's thoughts", became very popular in the northern newspapers in Oulu and Vaasa. Mäkelä did not consider it important to write about the finesses of communist peasant policy, he just tried to win the support of rural population by claiming that the interests of the rural people and the urban working class were similar and that other parties did not work for their interests. Although trying to compete with other parties for the support of rural population, Mäkelä was not guilty of simple labelling, which characterised the writings of the SKP leadership. Instead of communist declarations, he discussed with people and used popular or biblical phrases. Mäkelä’s ideas reflected commitment to the traditions of the Finnish labour movement both in Finland and America; Mäkelä had worked in America between 1899 and 1907 and formed his socialism there. (Saarela 1997, 5478; Norrena 1993, 193-234).

Toivo Vuorela, who worked as a secretary of the socialist workers' and smallholders' parliamentary group from the summer of 1924 to the spring of 1925, strongly supported the creation of a looser electoral organization instead of a new party. (Saarela 2008a, 76-77). All the Finns with American background were, however, not satisfied with that organizational pattern. Niilo Wälläri, the ex-SSTP chairman, though in prison, wanted to present his opinion of the organizational structure of Finnish communism. His articles, in the prisoners' secret paper Elämää yössä Wälläri, criticised the idea of a party of professional revolutionaries as narrow. He did not agree that a small but well-organized and determined group could accomplish more than wide masses. In Finland the emphasis on secret organization had indicated condemnation and shunning of a mass party. Wälläri reminded that the revolution was made by the working class and only a wide movement could bring the masses into the fight. In his opinion, 
this required large associations in residential areas, not in work places, as the communist doctrine indicated.

Wälläri and some other ex-leading SSTP-members considered the 'rigid policy' of the SKP to be the main reason for the loss of supporters and influence. They regarded it as odd that the elements presenting doubts within the movement had been pushed aside. They also demanded a change in the relation of the SKP towards social democrats; it was all right to criticise the right in the SDP, but, in order to be unified with the social democratic workers, it was necessary to have a moderate attitude towards the left. Wälläri and his companions also hinted that those living outside Finland did not entirely understand the situation in the country and should therefore not to have any absolute decision making power regarding Finland.

After his release in December 1926, Wälläri continued his fight for larger organizations. He considered the associations of the electoral organization too small and wanted to create larger associations. He received support from some leading members of the trade union movement, but those who had created the electoral organization or the SKP functionaries thought that Wälläri represented "the illusion of legalism". (Saarela 2008a, 110-118).

The condemnations of the SKP leadership intensified in the spring of 1929, and Wälläri and others in Finland were dubbed "right-wingers" who created panic and spirits of surrender and did not care about the interests of the class struggle. The SKP leadership wanted to get rid of Wälläri who, despite this pressure, left the post of editor in Työväenjärjestöjen Tiedonantaja, the main organ of the movement in Finland, only in October 1929. Wälläri and his companions formed a loose organization, the Left group of Finnish workers which was regarded as a disruptionist group by many Finnish communists in Finland. It did not win much support outside Helsinki. (Hodgson 1967,129-138; Saarela 2008a, 736-751). 


\section{American impact?}

The cases of Alanne, Laukki, Mäkelä and Wälläri seem to indicate that the traditions of the Finnish labour movement prior to the Civil War, were better preserved in America than in Soviet Russia, and perhaps only partly remained in Finland in the early 1920s. The American experience strengthened commitment to large workers' associations and bred an unwillingness to accept small cells as a principle of organization. It is also evident that those returning from America presented more open solutions than the representatives of Finnish communism in Soviet Russia. That is, their proposals were formed on the basis of achieving influence rather than on protecting orthodoxy. This may have reflected the American attitude, although it was also the attitude of the Finnish labour movement before the Civil War. It is also evident that the American experience had taught flexibility, while living in Soviet Russia had narrowed the perspective among those who had escaped from Finland in the spring of 1918.

Mäkelä exemplifies that the American experience could survive even in Soviet Russia. Not even the bad experiences of the abortive revolution in Finland in 1918 could make him a strong supporter of Bolshevik organizational ideas. In this respect Yrjö Sirola, one of the prominent leaders of the Finnish revolution and the first chairman of the SKP, who also had American experiences from the early 1910s (Salomaa 1966, 149-169), represented a more typical example of those who had escaped from Finland in 1918 and forsaken the ideas of the Finnish labour movement and committed themselves to Bolshevik doctrines. It is obvious that as a leader of the revolution and a communist party, Sirola had to commit himself much more strongly to the Bolshevik ideas than Mäkelä, who did not bother with the Bolsheviks or other international communists, but lived among the Finns throughout the 1920 s and 1930s.

All the Finns with an American background and without the experience of the abortive revolution in Finland did not, however, prove eager to pursue loose and large organizational forms 
but committed themselves to the standpoints of the Communist International and the SKP. William Tanner, who remained in Finland in 1924, worked in 1925-26 as an organizer for the Socialist workers' and smallholders' electoral organization and for the rural workers' trade union movement in eastern Finland. This work won him popularity and he was elected as a member of parliament in Viipuri's eastern district in 1927. In his work as a member of parliament, Tanner manifested communist orthodoxy. (Saarela 2008a, 430, 609) Also Toivo Vuorela stayed loyal to the International, although he quarrelled with the SKP leadership in 1926 when he, in order to avoid the imprisonment in Finland, returned to America without the permission of the SKP. Although the SKP sent its reprimand to America, Vuorela rose to a lead position in the Finnish labour movement in America (Kostiainen 1978, 55, 114).

This was not the case with Severi Alanne, who after his return to the United States ran for governor in Wisconsin in the fall of 1924 and was shortly, thereafter, accused of right-wing politics and expelled from the communist movement, which remained loyal to the Communist International. (Kostiainen 1978, 184; Sulkanen 1951, 273). Leo Laukki remained in the International, although he had been ousted from SKP leadership as early as 1925. The conflict within the SKP in 1923 onwards, was mainly between those who had been leaders in the Finnish revolution: Kullervo Manner, Yrjö Sirola, Otto Ville Kuusinen - and Finns who were born in St Petersburg and joined the Bolsheviks in the first decade of the twentieth century. Although Laukki was elected to the leadership of the SKP as a 'neutral' outsider, he joined Eino Rahja in the internal struggle. In that struggle it was easier for the Manner-Kuusinen-Sirola group to remove Leo Laukki from leadership than Eino Rahja. Thus Laukki was not re-elected in the central committee of the SKP in the party congress in 1925. After that he worked as a teacher at the Sverdlov University, at the Institute of Railroad Traffic at Dnepropetrovsk, and also as a newspaperman in Persia. Laukki was killed in the purges in 1938. (Paastela 2003, 132, 219-252 William Tanner, who had es- 
caped to the Soviet Union in the early 1930s, was imprisoned in the Soviet Union in 1935 and also killed as a result of the purges (Rentola 1994, 29).

\section{The Impact of Finnish communism?}

During the latter half of the 1920s the impact of the American Finns on Finnish communism was diminishing. The direction of the impact was rather from Finnish communism to the Finnish labour movement in America. This was evident through visits that the leadership of the SKP made to America from 1925 onwards. Yrjö Sirola spent a year in the United States from October 1925, in order to dissuade the Finnish socialist organization from language based organizational forms and to further its proper affiliation in the American Workers' Party. (Salomaa 1966, 296-297). The contradictions between the Communist Party of the USA and Finnish communists in America prompted Kullervo Manner and Aino Kuusinen to travel to America in the spring of 1930. Manner's visit was short but Aino Kuusinen stayed over three years. (Kostiainen 1975, 234-254).

Vuorela's example proves that the SKP leadership wanted to control migration from Finland to America. Besides Vuorela there were, however, others who, under the threat of imprisonment or for other reasons, left Finland for America. For instance Bruno Tenhunen, a newspaperman from Kuopio returned to Canada, where he had spent his childhood, in the spring of 1927 in order to avoid the imprisonment (Saarela 2008a, 125). Untamo Mäkelä, the son of Santeri Mäkelä, decided, to his wife's and children's surprise, to leave Finland after having served his time in prison in 1928. (Lehto 2010, 11-14). Martta Lehtonen's decision to move to Canada in November 1927 was even more surprising; she had been elected as a member of parliament in the election that had occurred the previous summer and had barely started her career when she decided to leave for Canada. (Saarela 2008a, 159). 
Although Finnish communism had a greater impact on the Finnish labour movement in America during the latter half of the 1920s, its direction was to change, as the recruiting of American Finns to Soviet Karelia began in the early 1930s. Thousands of Finns, who moved to Karelia in order to build socialism in Finnish colours, brought with them not only American technology, but also their way of thinking, which was not tolerated by the Soviet authorities. The discontent of the American Finns with the Soviet conditions couple with Soviet fear of foreigners soon led to disagreements. ${ }^{12}$ The SKP leadership did not demonstrate an eagerness to defend the American Finns. Their fate became a sad experience over which the SKP leadership wanted to draw a veil. (Rentola 1994, 23-74).

\section{Bibliography}

Ahola, Tero (1973): Leo Laukki Amerikan suomalaisessa työväenliikkeessä (Unpublished Master's Thesis). University of Helsinki, Helsinki, Finland.

Alapuro, Risto (1988): State and revolution in Finland. University of California Press, Berkeley, Los Angeles and London.

Carr, E.H. (1972 (1964)): Socialism in one country 1924-26. Volume three. Penguin Books, Harmondsworth.

Heikkilä, Jouko (1993): Kansallista luokkapolitiikkaa. Sosiaalidemokraatit ja Suomen autonomian puolustus 1905-1917. SHS, Helsinki.

Hodgson, John H. (1967): Communism in Finland: A History and Interpretation. Princeton University Press, Princeton.

Kangaspuro, Markku (2000): Neuvosto-Karjalan taistelu itsehallinnosta. Nationalismi ja suomalaiset punaiset Neuvostoliiton vallankäytössä 1920-1939. SKS, Helsinki. 
Kero, Reino (1983): Neuvosto-Karjalaa rakentamassa. Pohjois-Amerikan suomalaiset tekniikan tuojina 1930-luvun Neuvosto-Karjalassa. SHS, Helsinki.

Kero, Reino (1996): Suureen länteen. Siirtolaisuus Suomesta Yhdysvaltoihin ja Kanadaan. Siirtolaisinstituutti, Turku.

Kostiainen, Auvo (1975): Aino Kuusinen Kominternin asiamiehenä Amerikassa. In Turun historiallinen arkisto 30. Toimituskunta Pentti Virrankoski, Matti Lauerma, Kalervo Hovi. University of Turku, Turku.

Kostiainen, Auvo (1978): The Forging of Finnish-American Communism. A Study in Ethnic Radicalism. University of Turku, Turku.

Kujala, Antti (1989): Vallankumous ja kansallinen itsemääräämisoikeus. Venäjän sosialistiset puolueet ja suomalainen radikalismi vuosisadan alussa. SHS, Helsinki.

Lackman, Matti (1985): Taistelu talonpojasta. Suomen Kommunistisen Puolueen suhde talonpoikaiskysymykseen ja talonpoikaisliikkeisiin 19181939. Pohjoinen, Oulu.

Lehto, Matti (2010): Untamo Mäkelä. Vasemmistoliiton Vimpelin yhdistys, Vimpeli.

Majander, Mikko (1998): The Soviet View on Social Democracy: From Lenin to the End of Stalin era. In: Saarela, Tauno \& Rentola, Kimmo (eds.): Communism: National \& International. SHS, Helsinki.

McDermott, Kevin \& Agnew, Jeremy (1996): The Comintern. A History of International Communism from Lenin to Stalin. Macmillan Press, Basingstoke and London.

Norrena, Leevi (1993): Talonpoika, pohjalainen - ja punainen. Tutkimus Etelä-Pohjanmaan Järviseudun työväenliikkeestä vuoteen 1939. SHS, Helsinki.

Paastela, Jukka (2003): Finnish Communism under Soviet Totalitarianism. Oppositions within the Finnish Communist Party in Soviet Russia 1918-1935. Kikimora Publications, Helsinki.

Peltonen, Matti (1992): Talolliset ja torpparit. Vuosisadan vaihteen maatalouskysymys Suomessa. SHS, Helsinki.

Rentola, Kimmo (1994): Kenen joukoissa seisot? Suomalainen kommunismi ja sota 1937-1945. WSOY, Helsinki. 
Saarela, Tauno (1996): Suomalaisen kommunismin synty 1918-1923. KSL, Helsinki.

Saarela, Tauno (1997): Santeri Mäkelä vuoden 1918 jälkeen. In: Tauno, Saarela (toim): Talonpoikainen sosialisti - Santeri Mäkelä poliittisena toimijana ja kirjailijana. THPTS: Helsinki, pp. 54-78.

Saarela, Tauno (1998): Tuhatmarkkasia, miljoonia ruplia, dollareita. SKP:n tilinpäätös 1920-luvulta. In ... vaikka voissa paistais? Venäjän rooli Suomessa. Juhlakirja professori Osmo Jussilalle 14. maaliskuuta 1998. Toimittanut Jorma Selovuori. WSOY, Helsinki 1998, pp. 276-295

Saarela, Tauno (2008a): Suomalainen kommunismi ja vallankumous. SKS, Helsinki.

Saarela, Tauno (2008b): Finnish communism, Bolshevization and Stalinization. In: Laporte, Norman, Morgan, Kevin \& Worley, Matthew (eds.): Bolshevism, Stalinism and the Comintern. Perspectives on Stalinazation, 1917-1953. Palgrave Macmillan: Basingstoke and New York, pp. 188-205.

Saarela, Tauno (2009a): Dead martyrs and living leaders: the cult of the individual within Finnish communism, Twentieth century communism. Issue one. Communism and the leader cult pp. 30-49.

Saarela, Tauno (2009b): Nordic communists in the Communist International. In: Götz, Norbert \& Haggren, Heidi (eds.): Regional Cooperation and International Organizations. The Nordic model in transnational alignment. Routledge, London and New York, pp. 233-247.

Saarela, Tauno (2009c): Solidaritet från öst och väst. Den finländska kommunismen och den internationella solidariteten under 1920-talet. Historisk Tidskrift för Finland 2/2009 pp. 122-138.

Salomaa, Erkki (1966): Yrjö Sirola - sosialistinen humanisti. Kansankulttuuri, Helsinki.

Savolainen, Erkki (1978): Niilo Wälläri. Legenda jo eläessään. WSOY, Porvoo.

Sevander, Mayme (1996): Red Exodus: Finnish-American emigration to Russia. Työmies Society, Superion

Soikkanen, Hannu (1961): Sosialismin tulo Suomeen. Ensimmäisiin $y k-$ sikamarisen eduskunnan vaaleihin asti. WSOY, Porvoo, Helsinki. 
Sulkanen, Elis (1951): Amerikan suomalaisen työväenliikkeen historia. Amerikan Suomalainen Kansanvallan Liitto ja Raivaaja Publishing Company, Fitchburg.

Upton, Anthony F. (1980): The Finnish Revolution 1917-1918. University of Minnesota Press, Minneapolis.

\section{Notes}

1 On the revolution and its aftermath, for instance, Upton 1980; Alapuro 1988.

2 For instance, McDermott and Agnew 1996, 12-27.

3 On Finnish communism, Saarela 1996; Saarela 2008a; Saarela 2008b.

4 Valtavat työläisjoukot Helsingissä Saccon ja Vanzettin muistoa kunnioittamassa, Työväenjärjestöjen Tiedonantaja (TT) 25 August 1927; Pohjolan työkansa liikehti marttyyrien eloituksen johdosta, Pohjan Voima 30 August 1, 1927; Suuri vastalausekokous Turussa Vanzettin ja Saccon murhan johdosta, TT 31 August 1927.

5 On Laukki's background, Ahola 1973; Kostiainen 1978, 130-131.

6 National archive of Finland, Detective Central Police's archive, personal file no 730 (Toivo Vuorela). It is possible that Vuorela lied to the Detective Central Police and moved to America only after the Civil War, Kostiainen 1978, 55.

7 On Alanne’s background, Kujala 1989, 190-191, 255-259; Heikkilä 1993, 56, 58-60.

8 On Federated Farmer-Labor Party, Carr, 1972 (1964), 246-249.

9 On Alanne's opinions, Saarela 2008a, 65-66.

10 On Tanner, Kostiainen 1978, 128-130, 136, 161.

11 On the change, e.g., Majander 1998, 73-77.

12 For instance, Kangaspuro 2000; Kero 1983; Sevander 1996. 



\section{Cultural communism}





\section{Class struggle in the cemetery ${ }^{1}$}

The Finnish Civil War ${ }^{2}$ was fought at the beginning of 1918 between the revolutionary Reds and the counter-revolutionary Whites. The war broke out after the Russian revolutions had caused the collapse of Russian authority in Finland, which was at that time part of the Russian Empire. The war was a result of the inability of the labour movement and other parties to divide power between themselves and to solve other acute problems.

The actual fighting lasted almost one hundred clays, from the end of January to the beginning of May, when the last of the Reds surrendered or escaped to Soviet Russia. During the war 3600 Reds and 3100 Whites were killed in action, 8380 and 1650 were executed and over 12000 Reds died in prison camps during the summer.

The war didn't end with the cessation of armed conflict. Even though Finland was for the most part a democracy during the 1920s, and almost everyone could participate in elections, the frontlines of the war were manifest in Finnish society. There was, for instance, a tendency in Finland for the state to exercise very active control over civil society, especially over newspapers and associations, and attempts were made to prevent criticism of the prevailing institutions and their representatives. This tendency to control civil society and efforts to resist this control extended to include, of all places, cemeteries. 


\section{Keeping the graves in repair}

During the Civil War death was a frequent visitor to the families of workers. The task of caring for the orphans, homeless and those in prison camps fell first and foremost to the workers and their supporting organisations. The dead were not forgotten, either. They were remembered in the songs dedicated to the memory of the fallen and executed, and on the pages of memorial albums.

Already in the summer of 1918 efforts were being made to locate the graves of the executed in - or outside - cemeteries. After the war permission was granted to move the bodies buried outside cemeteries into them at the request of relatives, friends and other interested individuals. In many places, however, there were so many working-class people in the graves that it fell to the local labour associations to take care of them. Youth organisations often took the initiative for the municipal associations, trade unions or all the organisations of a town or a commune to create a special committee to keep the graves. ${ }^{3}$

These committees started their work by collecting money for tidying the graves every spring. In practice, they bought mould, spread it on the graves and planted grass and flowers. In some places the committees even tried to persuade the municipal councils to give money for the upkeep of the graves. ${ }^{4}$ However, these efforts were not generally successful. The right-wing parties were usually against such appeals. If the municipal councils did react positively towards them, the bourgeois parties could even appeal to the governor to have the decision revoked. ${ }^{5}$

\section{Monuments}

The labour movement was not, however, satisfied with flower bedecked graves. In September 1919, a proposal was made during a congress of Social Democratic Youth Union to erect monuments in memory of the Red victims. ${ }^{6}$ Many workers across the country, 
especially in those towns and villages where many Reds had died, had the same idea.

However, it was not easy to realise this dream because the ecclesiastical and secular authorities were united against it from the very beginning. Appeals for money for the monuments were turned down by the communal or town councils. Therefore, such appeals were often mere demonstrations. In Helsinki, for instance, the local socialist municipal association decided in 1921 to apply for the sum of one million marks in order to put up a monument. ${ }^{7}$

This kind of demonstration did not satisfy everyone. In Turku it was decided to resort to more strenuous measures. At the end of April 1921, just before May Day, local workers were able to celebrate the appearance of a monument to honour the sacrifice of the Reds. The monument, made of red granite, was almost three metres high and weighed over a ton, and yet it made a sudden appearance in the cemetery during one night, even though the cemetery was surrounded by a high stone wall and its iron gate locked. Nobody admitted knowing how the monument had appeared in the cemetery. There was speculation in Turun Sanomat, the local right-wing newspaper, that the monument had been lowered from an aeroplane.

Only a few members of the local youth association knew how the monument had arrived in the cemetery. In fact, young stoneworkers had cut the monument in stone and had transported it by a cart pulled by three horses near the cemetery. Twenty-five young men made a hole in the stone wall for the horses and cart, drove the monument to the grave and erected it. After that the horses and cart were taken away, the hole closed and all the tracks were covered - a miracle had been wrought.

The monument remained, even though the authorities had no enthusiasm for it. Only the metal plaques and red flag, which were supposed to be fixed to the monument, were confiscated; the man in charge was arrested and fined. ${ }^{8}$

In other places such efforts were not as successful. In Varkaus, where the Whites had executed one hundred Reds, the gover- 
nor ordered local policemen to prevent erection of a monument because nobody had requested a permission to put it up. In his opinion, the epitaph engraved on the monument, 'You gave your best for your ideas, was designed to disrupt the public order. The dispute with the governor was not yet resolved when the monument, which weighed about two tons, disappeared one night. The disappearance was less of a miracle, compared to the one in Tur$\mathrm{ku}$, for it was easy to follow the tracks in the snow up to the holes in the ice covering the nearby lake. The horses of the Ah1strom Company, the local paper mill company, were also tired and wet in the morning. ${ }^{9}$

The next spring (1922) even the people of Häme, often accused of being slow, reacted quickly at plans to put up monuments on the Red graves. The ecclesiastical administration asked the local governor in Hämeenlinna to have the monument removed from the grave. Policemen visited the grave one night and broke down the monument, leaving it scattered in three parts on the grave. Those in charge of putting up the monument removed the parts to another grave. But that was not enough for the police and the church council. They demanded total removal of the monument from the cemetery. This was not done before the monument was blown up one night. During the same spring other monuments were broken or stolen elsewhere in Häme, the area where the heaviest battles of the Civil War were fought. ${ }^{10}$

It was not always easy to put tip a tombstone, even on the grave of an individual, and such plans were often stopped by the authorities. This is what happened in Suomussalmi. When relatives and friends set out to carry the tombstone they had brought to the cemetery, they found it had been somehow removed from the courtyard of the local cooperative store and placed in a nearby well. The local police chief declined to investigate how the tombstone had got into the well; when he saw the word 'murdered' on the stone, he concluded that the attempt to erect the tombstone was a demonstration, and denied permission. ${ }^{11}$ 


\section{Memorial occasions}

Keeping the graves in good repair and trying to erect monuments on them were not the only tasks of the elected committees. Gradually, they began to organise memorial ceremonies at the gravesites. These occasions sometimes included marches to the graves, but usually only speeches, song, music and laying funeral wreaths on the graves.

In May 1926 the committee elected by the labour organisations in Helsinki even made a suggestion that memorial occasions should be arranged everywhere in the country on the same day, the second Sunday of June. Even under difficult circumstances the committee wanted these ceremonies to be comparable to the Freedom War celebrations, arranged everywhere by the Whites, who had won the war, and at the same time be a counterbalance for them. ${ }^{12}$

The initiative was not successful. The date was not changed, and the gatherings at the gravesites took place as before, the visits occuring on the day the fighting during the Civil War had ended in that district. At some locations the march of the First of May took the participants to the graves; usually the memorial occasions took place during the late spring and early summer and the graves were often in good repair by Whitsuntide. Then there was also more free time to spend the day at the gravesites remembering the dead. In Kymi and in Viipuri the occasions took place sometimes in May, sometimes in August or September. ${ }^{13}$

\section{Instructions of the state}

The bourgeois elements of the country didn't like the idea of paying honour to the Reds, not even dead Reds. The removal of the monuments was a clear manifestation of their opposition.

In order to clarify the situation, at the end of May 1923 the Ministry of the Interior issued instructions ${ }^{14}$ regarding visits to the gravesites and the erection of monuments. According to these 
instructions relatives and friends were allowed to express their mourning and lay flowers on the graves. The authorities were to prevent large numbers of people from gathering at the cemeteries with the intent of staging a demonstration. These included visits arranged by special organisations, processions, depositing of wreaths, agitating speeches and other ceremonies near the graves. These kinds of visits were considered to be a demonstration in favour of rebellion and acts of rebellion, and according to the law such acts were criminal offences.

Permission was required from the ecclesiastical authorities to erect monuments at the cemetery. The monument or the epitaph on it was not to be insulting or offensive. If the monument expressed anything more than the natural and rightful mourning of the relatives, it could be removed at the discretion of the ecclesiastical authorities.

After the instructions were issued by the Ministry of the Interior, and after the Court of Appeals in Turku ruled that the effort to put up the monument in Hämeenlinna constituted a crime, ${ }^{15}$ the efforts of the grave committees to put up monuments diminished. Nevertheless, they challenged the instructions by keeping the graves in repair and by arranging memorial occasions beside them.

In spite of these rulings the attitude of the authorities towards the graves and memorial ceremonies was inconstant. New instructions left plenty of room for different interpretations. In Seinäjoki, for instance, the governor ordered the $40 \mathrm{~cm}$-high border around the grave to be removed. In his opinion, the border was 'only a communist provocation. ${ }^{16}$ In Kokemäki the local police thought it illegal to cover the grave with mould and flowers. As a result they scattered the mould and tore away the flowers. ${ }^{17}$

The attitude of the authorities towards memorial occasions was inconsistent. In Helsinki the police were usually content only to watch the proceedings; in Turku and Viipuri the whole occasion was sometimes forbidden, sometimes only songs and speeches were permitted, sometimes not even that. ${ }^{18}$ If the police could not prevent the event beforehand, they could punish the speaker later 
on. Usually the speaker was fined, but in Viipuri the court sentenced the offender to two months' imprisonment. ${ }^{19}$ On the other hand, the disappearance or destruction of the Red monuments was not investigated by the police. ${ }^{20}$

It was not always even necessary for the members of the labour movement to visit the grave to be punished. In Varkaus, for instance, a clerk of the local labour newspaper sold his photographs of the stolen monument to finance the case against the thieves of the monument. The local court fined him 500 marks for illegal collection of money. ${ }^{21}$ In Viipuri, on the other hand, sale of a postcard of the monument, produced for financing it, was permitted. ${ }^{22}$

\section{Room for only one interpretation}

Why were the authorities and the right-wingers so eager to prevent the erection of monuments and visits to the Red graves? Monuments and visits to graves don't appear very dangerous. The obvious willingness to remove monuments that weighed many tons indicates, however, that these were very important matters. Mere mischief probably isn't enough to explain it. It is easier to understand the significance of the deeds against the White interpretation of the Civil War.

For the victors of the Civil War it was natural to put up a heroic statue or a monument in every city, town or village, often with municipal revenues. ${ }^{23}$ It was a way to reinforce their interpretation of the events of 1918. By means of the monuments the Whites also continued their fight for freedom and independence. The monuments were also needed to make the winners forget their own terrible deeds during and after the war.

On 17 June 1923, the leading article of Uusi Suomi, the main organ of the right-wing Coalition Patty, expressed the opinion that in Finland there was room for only one interpretation of the Civil War. According to this opinion the Finnish people could be grateful only for those who gave their lives in order to liberate 
Finland from the Russian oppression. ${ }^{24}$ From this point of view the celebration of the Freedom War and the visits to the White graves were natural, but similar ceremonies beside the Red graves 'grossly offended the peace of the burial grounds and brought deep shame upon White Finland'. It was indecent to honour those who had risen 'against the independence and freedom of their own country and whose hands were directly or indirectly stained with the blood of peaceful people loyal to the laws of their nation. ${ }^{25}$

For the winners of the war, Red monuments were not only a desecration of historical heroic deeds. They also believed that this was a way to mobilise even the dead to agitate against 'the legal social system and peace of the country. To visit Red graves and to erect monuments on them was to praise and to idealise unlawful behaviour. Both acts were also considered to incite new crimes and to defy the social system bound by law. ${ }^{26}$

The Hämeen Sanomat, a right-wing newspaper in Hämeenlinna, showed its cleverness in interpreting the monument on Red grave in that city: '... the coarse stones hinted at some kind of popular movement, uprising, and the truncated cone indicated that this movement was not finished. ${ }^{27}$

Even though the winners of the Civil War dearly had the upper hand in Finland, they didn't trust their ability to establish their own version of the war by anniversaries, monuments and propaganda alone. In addition it was considered necessary to resort to authoritarian orders and punishments. In this way the force of law and the authority of the state gradually had its effect on civil society. This in turn reflected the strong commitment of White Finland to the tradition of legalism and its unwillingness to give citizens room for private initiative.

\section{Demonstration}

The Whites were, of course, right. Keeping the graves in repair and putting up monuments was a demonstration of the Reds 
against the one-sided White interpretation of the war. The workers wanted to show their respect to those who were considered to have defended workers' rights and to have fought for a just cause. But the workers also wanted to remind the winners of their unjust deeds in 1918. Even the red flowers on the graves were intended to remind 'the slaughterers passing by of those terrible acts which they, in their thirst for blood, had committed and of the love that working people felt for those victims. To remember and to be horrified by the deeds of the Whites was a central idea in 'Hymn of the Graves', often sung during memorial occasions. ${ }^{28}$

On the other hand these monuments and memorial occasions were also an expression of encouragement: 'We don't cry forever; weak are those who are overwhelmed by their grief', is a phrase which resounds from 'Hymn of the Graves'. The power of grief could he exceeded by acts like the appearance of the monument in the Turku cemetery. Such acts suggested that workers could do something else, seemingly incredible at first sight. ${ }^{29}$ To gather beside the graves was also to strengthen one's own attitudes. At least Villiam Rossi, the chairman of the socialist municipal association in Kajaani, said that to visit the graves was 'to multiply by ten thousand the revolutionary power of the class struggle. On the other hand the visitors felt beside the graves 'as if they got their new enthusiasm to fight for the liberation of the working class. ${ }^{30}$

It is obvious that these feelings were whipped-up more actively in the labour movement to the left of the Social Democrats, even though neither the Socialist Workers' Party (1920-23) nor the Communist Patty mentioned anything about them in their resolutions.

\section{The burial of the grave struggle}

The total suppression of the socialist workers' movement in the beginning of the 1930s changed the character of the fight about the graves. Memorial occasions were no longer possible. Policemen even went to the cemeteries to blow out the candles lit on 
Red graves on Christmas Eve. They also removed the red ribbons of funeral wreaths laid secretly on the graves. ${ }^{31}$

After the Winter War (1939-40) policemen were allowed to discontinue their important guard duties. At that time the official attitude changed, and even the deceased Reds 'were publicly included in the nation'. Memorial occasions were permitted at Red gravesites and the Reds who had been buried outside cemeteries could be moved into them. In some places monuments were put up on graves. The fight over these graves was not, however, totally put to rest until the 1960s when most of the Red graves finally got their own monuments. ${ }^{32}$

Although the struggle in the cemeteries is over, Finnish society still bears the scars of the Civil War. The lack of trust the winners of the war had in their ability to establish their interpretation of the war through their propaganda made it necessary to rely on the orders of those in authority, and on punishments. This was an effective way to prohibit discussion in Finnish civil society and to suppress criticism of those in authority. After the Second World War other factors have also contributed to the same tendency, but the Civil War laid good foundations for them.

\section{Notes}

1 This article is my translation of my Luokkataistelua hautausmaalla in Ajankohta, in Mikko Majander (ed.), Poliittisen historian vuosikirja 1992 (Helsinki: Tutkijaliitto, 1992).

2 The war has many names. For the Whites, who won the war, it was a Freedom War, for the Reds an uprising, a revolution or a Class War. In the 1960s the term Civil War became customary, but there are still disputes even among historians about the name of the war. 
3 On the birth of committees to keep the graves in repair see for instance, Helsingin punaisten hautojen huoltokomitean pöytäkirjat 1920-23 and Kotkan Työväen-Järjestöjen valitseman, vuonna 1918 väkivaltaisesti surmansa saaneiden järjestöjen jäsenten hautojen huoltamiskomitean toiminnasta 1922, Punavanki- ja hautamuistomerkit, Työväen Arkisto (TA); Toimintakertomus Oulun sos.-dem. kunnallisjärjestön asettaman hautatoimikunnan toiminnasta lokak. 15. p:stä 1919 maalisk. 4. p-ään 1920, Oulun eteläisen vaalipiirin piirijärjestön paperit, Suomen Sosialistisen Työväenpuolueen arkisto, TA.

4 See for instance, Helsingin punaisten hautojen huoltotoimikunnan pöytäkirjat 5.5. ja 19.11.1921, 24.4.1923, Punavanki- ja hautamuistomerkit, TA.

5 Savon Kansa 18.2.1921 'Valkovihan uhrien hautojen kuntoonpano Kuopiossa'; Eino Jutikkala: Tampereen historia Vuodesta 1905 vuoteen 1945. Tampere $1979,606-607$.

6 Aimo Kairamo: Ponnistuksien kautta vapauteen. Sosialidemokraattinen nuorisoliike. Osa I. 1906-1922. Toim. Harri Kivenmaa. Joensuu 1986, 265.

7 Helsingin sosialistinen kunnallistoimikunta 18.5. ja 7.6.1921, edustajisto 16.6.1921, Helsingin sosialistisen kunnallisjärjestön paperit, TA.

8 Niilo Kavenius: Turun punaisten hautapatsas "ilmaantui" keväällä 1921. In Ennen ja jälkeen 1918. Pori 1972, 109-112.

9 Hannu Soikkanen: Varkauden historia. Helsinki 1963, 654; Suomen Sosialidemokraatti (SSd) 26.4.1922 'Valkoisen huliganismin luvattu maa'; SSd 27.4.1922 'Varkaudessa tapahtunut punaisten haudan häväistys'; SSd 3.5.1922 'Varkauden hautapatsasvarkaus'.

10 The speech of Kalle Myllymäki. Valtiopäivät 1924. Pöytäkirjat, 2105-2108.

11 Työväen Lehti 7.4.1921 'Eräs valkoisen terrorin uhri Suomussalmella'.

1217 8.5.1926 'Työläissankarien muisto'.

13 Esko Korkeamäki: Valtaa sorretuille. Työväenliikkeen kehitys Viialassa 1870luvulta alkaen II maailmansotaan saakka. Toijala 1983, 165; Pohjan Voima 3.2.1927 'Taistelijaimme muisto säilyy'; Suomen Työmies 29.5.1922 'Surujuhla Malmin hautausmaalla'; TT 18.8.1925 'Viime sunnuntainen muistotilaisuus Viipurin veljeshaudalla'; SSd 24.5.1928 'Muistojuhla Tammisuolla Viipurissa'.

14 On the instructions, the statement of Gunnar Sahlstein, the Minister of the Interior, Valtiopäivät 1924. Pöytäkirjat, 2099-2100.

15 Lars Björne: "... syihin ja lakiin eikä mielivaltaan..." Tutkimus Turun hovioikeuden poliittisista oikeudenkäynneistä vuosina 1918-1939. Vammala 1977, 213-214.

16 Aulis J. Alanen: Seinäjoen historia I. Vuoteen 1931 eli kunnan jakautumiseen kauppalaksi ja maalaiskunnaksi. Seinäjoki 1970, 135; SSd 2.6.1923 'Työläisten joukkohauta Seinäjoella'. 
17 SSd 11.6.1923 'Hautojen häpäisemiset jatkuvat'.

18 Pohjan Kansa 7.6.1923 'V. 1918 murhattujen työläisten haudat'; Työväenjärjestöjen Tiedonantaja (TT) 24.9.1925 'Turun poliisimestari vihaa vainajia'; See also the examples mentioned by Kalle Myllymäki and J. F. Aalto. Valtiopäivät 1924. Pöytäkirjat, 2107, 2111-2112.

19 Björne 1977, 213-214; TT 14.11.1925 'Veljeshaudalla puhumisestakin tuomitaan'.

20 Björne 1977, 216; the statement of Gunnar Sahlstein, the Minister of the Interior. Valtiopäivät 1924. Pöytäkirjat, 2100-2101.

21 SSd 6.6.1923 'Varkauden varastettu hautapatsas'.

22 Arthur (Rönnqvist) Kansan Arkistolle 8.11. 1960, kirjeenvaihto, Kansan Arkisto (KA).

23. On monuments, see, e.g.Jutikkala 1979, 359; Rauno Enden: Heinolan kaupungin historia 2 (1900-1939). Jyväskylä 1989, 422-423.

24 Uusi Suomi 17.6.1923 'Sosialistinen hautakiihoitus' (la).

25 Hämeen Sanomat 23.5.1923 'Häväistys' (la).

26 Uusi Suomi 17.6.1923 (la); Hämeen Sanomat 26.5.1923 'Porvarillista velttoutta' ja 26.6.1923 'Kiihotusta ja vääristelyä' (la).

27 Hämeen Sanomat 16.6.1923 'Vieläkin Hämeenlinnan kapinallispatsaasta' (pk).la

28 See, e.g. TT 19.7.1925 'Valtava työväenjuhla Malmin työläishaudoilla'; Pohjan Voima 13.6.1925 'Sarastus', 'Raahesta'.

29 See, e.g. Suomen Työmies 30.4.1921 'Ohrana ymmällään ihmeen edessä; Suomen Työmies 8.5.1921 'Turun veljeshautapatsas'.

30 Työväen Lehti 10.8.1920 'Muistojuhla toverin kummuilla Kajaanissa'; Itä ja Länsi 31.8.1925 'Marttyyrien muisto'.

31. Puhelinsanoma 1120: Tampereen edustus pääosastolle 25.12.1934 ja Ilmoitus 210/28.1.1935, EK-Valpo Amp., Valtionarkisto.

32. Oiva Ketonen: Kansakunta murroksessa. Kesää 1918 ja sen taustaa. Porvoo 1983, 176-178; Ks. myös Ennen ja jälkeen 1918. Pori 1972. Maurice Carrez, 'Sites of the Red Massacres in Finnish Civil War. The Politics of Memory and its Re-Interpretation' in Ei ihan teorian mukaan. Toimittaneet Mikko Majander ja Kimmo Rentola. Työväen historian ja perinteen tutkimuksen seura, Helsinki 2012, p 93-101 ( https://helda.helsinki.fi/handle/10138/30043 ). 


\section{Oppressed worker or communist hero? Characters in Finnish communist magazines of the 1920s}

The communist movement was intended by its proponents to create new people with new values, attitudes and manners. Guidelines for these new people were given in the instructions on the tasks of a party member but also by presenting models for members and supporters. ${ }^{1}$ Such models were, for instance, Karl Liebknecht, Rosa Luxemburg and V.I. Lenin who were praised for having been energetic, unyielding and inspiring. Identification with them was, however, not easy - Lenin, for example, was regarded as a genius and infallible, which was probably not expected from every communist. ${ }^{2}$

More ordinary models for these new people were produced in fiction and its characters. In the 1920s, communist literature was not particularly committed to furthering the creation of communist heroes. Earlier socialist literature had, however, presented models to be adopted, such as Pavel Vlasov in Maxim Gorky's Mother, and Ernest Everhard and Martin Eden in Jack London's works. The Russian civil war heroes of Alexander Fadeev and Dmitri Furmanov, and Gleb Chumalov in Fjodor Gladkov's novel Cement, which described the era of socialist reconstruction, were also inspiring characters.

All these heroes went through a process of development 'through suffering and humiliation, through struggle, through ordeals, through weaknesses experienced, understood and con- 
quered'- and surmounted obstacles before them. They did not, however, dedicate themselves to the communist cause as totally as Nikolai Ostrovsky's Pavel Korchagin was to do in the 1930s. In other respects too they were more complicated characters. ${ }^{3}$

These books and their heroes created a model for writing short stories about workers and communists, as did the traditions of working-class literature in every country. ${ }^{4}$ This article considers what kind of working-class characters were presented in Finnish communist literary magazines in the 1920s.

\section{Finnish communism and its literary magazines}

Finnish communism was born in two countries, in Soviet Russia and in Finland. The leaders of an abortive revolution escaped to Soviet Russia in spring 1918 and founded the Finnish Communist Party (from 1920 onwards the Communist Party of Finland) in August. The party was captivated by the hope of immediate world revolution and yielded itself to the new ideas of communism. It was forbidden in Finland and its central organs were located outside the country up to the autumn of 1944. The party, however, cooperated with various organs and persons in Finland.

Within Finland, Finnish communism was formed around the Socialist Workers' Party which was founded in the spring 1920 and banned in August 1923. After that, Finnish communism in Finland was organised in various electoral, political and cultural organisations until they were banned during the summer of 1930 .

Finnish communism was a mixture of new communist ideas and the inherited traditions of the Finnish labour movement. At the ideological level both those in Soviet Russia and those in Finland were willing to accept new communist ideas, but in daily politics - under the threat of imprisonment and the dissolution of their organisations, while trying to win the support of workers and peasants - those in Finland preferred to follow their own labour traditions. For the party leaders in Leningrad or Moscow this gave rise to constant demands for ideological orthodoxy. Dis- 
continuity of speech and activities was characteristic for Finnish communism. ${ }^{5}$

The literary magazine was not a communist invention in the Finnish labour movement, and such a weekly had come out in Helsinki in 1902-6. In the 1920s, however, the enthusiasm for literary magazines was much greater. The Finnish communist youth published two literary weeklies: Liekki, which came out in Helsinki in 1923-30 and Revontulet which. appeared in Oulu between 1926 and 1930. Besides these, the pictorial magazine ltä ja Länsi and the spring and Christmas periodicals Rynnäkköön and Nuoren Työläisen Joulu, as well as the handwritten papers of the youth associations, all published fiction.

The communist youth founded literary magazines for many reasons. As early as 1916-17 there had been discussions among them about creating their own organ for workers' literary needs, but because of the Civil War and its aftermath the achievement of this objective had to wait until 1923. The magazines were also founded to raise money for the daily newspapers. The main reason for their publishing, however, was the challenge presented to the labour movement by commercial popular culture with its popular fiction, magazines and film. The literary magazines of the communist youth were intended to prevent the young workers from committing themselves to 'cheap and bad entertainment' and to keep them in the sphere of the movement's influence.

The magazines published texts of those authors who were of labour origins, wrote of workers' life or displayed sympathy for them or their movement. These writers included the Russians Maxim Gorky and Lev Tolstoi, the Americans Jack London and Upton Sinclair, the Frenchmen Anatole France and Henri Barbusse, and the Dane Martin Andersen Nexö. The famous short story writers Anton Tsekhov, Guy de Maupassant and Mark Twain were popular, too. New Soviet fiction was also introduced on the pages of the magazines, although as the example of Mikhail Zoshchenko indicates, they did not necessarily favour pro-communist writers.

Foreign writers were not the only ones to contribute to the magazines. Finnish young communists also wrote plenty of short 
stories. Among these authors were young writers who had already 'established themselves' by publishing a book or two and the editors of the magazines, as well as other less known writers. The magazines also organised writing contests in order to generate stories. In most cases the writers had only an elementary education behind them. As a result, they were less eager to theorise about literature and its tasks than to write short stories intended to tell how the workers lived and fought in the maelstrom of life. ${ }^{6}$

\section{The oppressed worker}

Inspiring communist characters were thus almost entirely missing in the short stories published in the magazines; the first numbers were, rather, full of stories describing the hardships of workers' lives. Agricultural work in particular was portrayed as toil which brought no improvement to one's life. Factory work, with its long and fatiguing working days, tight discipline and occasional fatal accidents, was no better. Even logging, characterised in Finnish literature as having romantic features, was exposed for its tough conditions. ${ }^{7}$ In such circumstances, the workers could take no professional pride in their work.

The short stories also told of other hardships suffered by the workers. Unemployment and poverty meant that young working women ended up in the streets as prostitutes, families were ejected from their homes, the elderly and orphans were neglected, and innocent people were imprisoned. ${ }^{8}$ These hardships were not presented in order to show the workers overcoming them; rather, they broke down under them - the characters could die, end up as beggars, drunkards or strike-breakers. ${ }^{9}$ Even glimpses of a brighter future could be destroyed - an escaping political refugee is shot at the border; a young worker studying singing dies at the point of success. ${ }^{10}$

This kind of story of workers' sufferings was typical of the literary tradition of the Finnish labour movement, which was very strongly influenced by realism and naturalist determinism. Typ- 
ical of the early Finnish realism was the passivity of the characters, their negative and pessimistic feelings - in some stories the only solution was death. These aspects were readily accepted in the labour movement at the turn of the twentieth century. ${ }^{11}$ The hard experiences after the Civil War in 1918 and the continuous political discrimination in the 1920s may have strengthened the negative tone of the stories.

According to this tradition it was believed that the dark colours of the stories would not only increase the knowledge of the injustice of existing society but also touch readers' emotions and strengthen their hatred towards it; the hardships were supposed to toughen people. This kind of story of sufferings can be found in Finnish communist magazines throughout the decade, despite the declared aim of the magazines that their stories should broaden the world view of their readers and strengthen their will for action. ${ }^{12}$ However, it was not until the autumn of 1928 that these stories of sufferings were actually criticised in Liekki. While it was accepted that they portrayed the real life of working people, they were also held to diminish it by not telling anything of the bravery of the workers' attitude towards that life. Liekki's critic recommended that the darkness of the stories should be brightened by the great future that lay before the working class. ${ }^{13}$

In the summer of 1929 Ludvig Kosonen, the editor of Liek$k i$ and the only person in the communist youth movement who tried to explain the value of literature in the struggle of the workers, said that such stories of workers' sufferings belonged to an earlier period when the working class was weak and unorganised and set its sights on attaining equal status with the bourgeoisie. In the 1920s, on the other hand, the working class was trying to reach the dominant position in society. The task of proletarian art was to kindle emotions for the great cause and goal of the working class. Along with depictions of misery, the stories should therefore tell about 'the magnificent heroism, the infallible belief in the future and indomitable fighting spirit' of the working class - the art should be a standard-bearer for the future. ${ }^{14}$ 
Kosonen himself, however, did not at that time present any characters who would have filled these demands, but rather described unheroic members of the working class. He even thought that the ideal persons did not yet exist. ${ }^{15}$ It was only in the early 1930s, when Kosonen had escaped to the Soviet Union, that he published a book which told of the youth movement in Helsinki as he would have liked it to have been. ${ }^{16}$

\section{The villains}

The stories of workers' sufferings did not present positive heroes but rather expressed criticism of existing society and introduced its 'villains. The employers were often described as immoral and unscrupulous persons, who, for instance, when work accidents happened were worried only about the interruption in production. ${ }^{17}$ Factory owners and their sons, foremen, farm owners and also priests were depicted as seducing, even raping, young working women. ${ }^{18}$ The villains also included the authorities: a judge could sentence a woman he had seduced in prison for childmurder; ${ }^{19}$ a successful and respected undertaker was revealed as a bootlegger ${ }^{20}$ a sawmill owner was planning to burn his timberyard and to frame the strikers as victims. ${ }^{21}$ And the rival youth associations were connected with drinking, fighting and a generally indecent life. ${ }^{22}$

The stories of the injustices of society were often fictitious but sometimes they came quite close to actual incidents. After the banning of the Socialist Youth League and the arrest of dozens of its members at the end of 1925, Liekki published a story in which a 17-year-old boy, after a long time in custody, is accused of plotting high treason and is sentenced to prison for a year and a half. According to the story, the only crime committed by the young man was that he wanted to study in the labour organisation at the end of his long working day. ${ }^{23}$

Moral disapproval was not the only way to react against injustice. Violation of workers' civil rights produced stories mock- 
ing the institutions - courts of justice and political police - and persons behind these offences, as well as their ways of thinking. Armas Äikiä, the future member of the Terijoki government and the leading Stalinist in aesthetic discussions within the Finnish communist movement after the Second World War, placed his story in 'Benitoland' where 300 young workers are arrested because the newspapers have written about their plans for a bomb attack. The boxes presented as evidence and believed to contain dynamite turn out to contain ski wax. Nevertheless, the youngsters are sentenced to prison because they have betrayed the state by claiming that ski wax is dynamite and thus misled the political police and the court and ridiculed them which is the same as preparation for the revolution. ${ }^{24}$

Stories ridiculing the political police, or 'okhrana', as it was called according to its Russian predecessor, were also common. It was usual to tell how its actions were based on rumours and misunderstandings. In one of the stories some 'okhrana' detectives overhear someone in the Helsinki labour hall talking about obtaining arms for the following Saturday. On that day the detectives form a cordon around the labour hall, but find out that what they had heard was the members of a theatre group talking about their next play. ${ }^{25}$

This kind of story was written in order to challenge the legitimacy of the authorities and the whole existing order of society. Although they urged the working youth to the same kind of mockery, they seldom presented actual humorous characters themselves.

\section{Labour movement as hero}

There were no individual heroes in the early stories; the hero was, rather, the whole labour movement. Thus there were many stories about young working men or women who were saved from ruining their lives by joining a labour youth association. ${ }^{26}$ Accordingly, the labour movement was in some stories described in terms 
of an actual place of solidarity which served as a counterbalance to their gloomy working life - a place where the workers could study, have social evenings and spend their leisure time, without having to confront the outside world. ${ }^{27}$ For instance, the youth associations used to spend their summer weekends in their own (hired) places, perhaps on nearby islands, to which the youth would make excursions by rowing boat. In this respect the stories did not follow the instructions of the communist movement, which demanded that their organisations should orientated towards activity; they should not be places where people only spent time together.

Although the labour movement was portrayed as of great importance, its heroic qualities were nevertheless very much understated. The stories in the magazines very seldom described the strength of the labour movement, and heroic overtones were much more frequent in their poems. In the early years the stories portrayed even strikes in pessimistic tones - the strikes failed and the workers might become strikebreakers. ${ }^{28}$ There were, however, sometimes glimpses of class-conscious activities; for instance the children of the striking workers throwing stones at strikebreakers. ${ }^{29}$

The determination and the success of the striking workers became more evident in the latter half of the decade $\mathrm{e}^{30}$ - perhaps as a reflection of large strikes in the country. ${ }^{31}$ The collective appeal of the labour movement also became more commonly portrayed in the last years of the decade. A group of young workers spending their weekends on an island could, for example, persuade the young men of a nearby village to change their attitude towards the working youth and join the ranks of the movement. ${ }^{32}$ Nevertheless, the stories were not particularly written in order to encourage organisational activities, even though these were regarded as very important within the communist movement. Therefore there were no stories by those living in Finland about creating a workplace organisation. Only a few articles originating from the Soviet Union and America told of workers who established cells in the factories. ${ }^{33}$ 


\section{Lone heroes}

The literary tradition of the Finnish labour movement was not entirely devoid of positive, inspiring heroes. Some writers had in the 1910s presented characters whose model was Spartacus, the rebellious Roman slave. ${ }^{34}$ By the 1920 s such heroes were untypical, although half-documentary, half-fictional stories of courageous fighting down to the last bullet in the Civil War could be seen as a continuation of the same type. ${ }^{35}$

Such heroes were more likely to be placed in other parts of the world, and young Finnish writers made up adventure stories about Russian revolutionaries and rebels in Latin America. ${ }^{36}$ These stories were written in a different style, possibly copying those numerous adventure stories originating from America, Britain, Germany, Sweden, and the Soviet Union. These stories were very common in the Finnish communist youth magazines, even though adventure stories in general were dismissed as trash in the same magazines. ${ }^{37}$

The most colourful of these stories takes place in a fictional Latin American state, Nicazuela, where poor vaqueros (cowboys), farm labourers and the workers of a few cities rise in rebellion. This event is so surprising that the president of the country dies of astonishment. The rebellion is, however, suppressed by a general who creates a dictatorship and puts the rebels in prison camps. In this phase of the story the hero, a Finnish seaman and ex-Red Guardist, enters the stage. He escapes from a prison camp with a native friend of his and, posing as an American, he moves to the capital of the country where he spreads the rumour that the dictator of the country has disappeared. At the end of the story the Finn is sitting in the office of the prime minister asking him to grant an amnesty to all political prisoners. His demands are supported by the announcement that the dictator is his prisoner and by the explosions sounding all around the city. The demands are, of course, accepted. ${ }^{38}$

This story presented a hero who was capable of both solving problems without difficulty and getting others to follow him. It 
is, however, doubtful whether the text was written in order to inspire readers to similar deeds - it was too unreal for that. This story was, more likely, intended to make fun of a common mould of popular fiction in the then young nation state of Finland. According to that mould, the Finns were an extraordinary people, no matter what part of the world they were to be found in. ${ }^{39}$

This kind of 'heroic determination' and 'brave action' from a few individual men was criticised in the magazines. ${ }^{40}$ It did, however, influence the stories which took place on Finnish soil and whose themes had connections with the Finnish labour movement. Liekki, for instance, published in March 1927 a story where an employer of a lumber site hires a notorious fighter and bootlegger to prevent the organisational work of a trade union agitator. This plan comes to nothing because the agitator is a former boxer and wrestler; he knocks out the disturber and continues his speech, with the result that 100 per cent organisation is established. ${ }^{41}$

In a story published in the first album of the Union of Proletarian Writers in 1929 the workers are inspired by the example of the hero. The story describes a young communist working in a saw mill. During his lunch hours and spare time he participates eagerly in discussions and begins to win support. One morning he does not come to work, and it is revealed that he has been arrested by the okhrana. This piece of news makes the workers stop their work, leave the saw mill and march to the labour hall, singing the International. ${ }^{42}$

The promise of an active movement inspired by an individual communist was not always thought so obvius and a young worker dedicating himself to the class struggle could also be somewhat problematic as a model. In a story published in Liekki in summer 1928 a young man wanted by the police comes to the youth meeting in the labour hall because it is his turn to give a lecture. In his speech he argues for the vanguard which is prepared for the revolution and can lead the masses towards it. When the police arrive at the hall, he does not try to escape, but explains to others that prison is a school for revolutionaries. ${ }^{43}$ This story is a good 
example of how the Finnish communists had difficulties in solving the problem of being a true communist and maintaining the movement's and personal possibilities for action.

\section{Class struggle and love}

Although in the Finnish communist movement love stories of the popular fiction variety were regarded as trash, Revontulet in particular published dozens of them in translation. ${ }^{44}$ Even the young communists wrote stories which told of the relations between young working men and women. In the early years of Liekki the stories tried to convince the reader that 'the working girl of one's dreams' would be found 'in the army of the fighters. ${ }^{45}$ In other words, it was possible to unite love, family life and activities in the labour movement if the aspirations of the two people involved were alike. Participation in the class struggle was usually regarded as a condition for living together. These stories did not reflect great passion but rather preached in favour of comradeship and against jealousy and possessiveness. ${ }^{46}$

The possibility of uniting love and activity in the movement was not a notion shared by all writers. Some of them created characters - usually young men - who decided to give up their beloved in order to dedicate their lives to revolutionary work. These persons also tried to convince others that the fight for socialist ideas was more important than home and family. ${ }^{47}$ This kind of story became more common in the last years of the decade and might have anticipated the puritanical heroes of 1930s Soviet literature for whom the private sphere was nothing in comparison with the public.

In the Finnish stories the happiness of love and family - as indeed of all good things - was in a sense tied in with the realisation of socialism, which was supposed to solve all problems. Maybe Liekki editor Ludvig Kosonen also believed in it, although his ideas for solving the contradiction between the seriousness of class struggle and carelessness and cheerfulness of love were not opti- 
mistic ones. ${ }^{48}$ Stories of love were very 'class-conscious'. They did not allow young workers to cross class boundaries for love's sake; love between a girl and a boy coming from different classes was seldom possible. ${ }^{49}$ Towards the end of the decade the possibilities in this respect increased a little, and whichever of them it was belonged to the labour movement could try to convince the other of the importance of making a similar commitment. ${ }^{50}$ On the other hand, any attempt to engage with a boy or girl of non-proletarian background was - even in love - seen as a deviation from the correct line of the class struggle. ${ }^{51}$

As love affairs or marriages crossing class boundaries were not common in Finland in the 1920s, this kind of story was not written in order to prevent them. The stories rather reflected a more general wish not to let the labour movement be tainted by bourgeois society. They also challenged the concept offered by love stories in other magazines, according to which it was possible for a rich man to fall in love with a poor girl and marry her. ${ }^{52}$

\section{Tradition and new ideas}

The short stories written by young Finnish communists in the 1920s thus ran along the lines of Finnish labour movement traditions rather than the new communist ideas. This was evident in the gloomy depictions of oppressed workers and in the moralising tones adopted towards the injustice of society. It was also traditional to portray the whole labour movement, rather than individual workers, as the hero of these stories.

Although there had been similar discussions in the Finnish labour movement as early as 1910, the criticisms of stories of workers' sufferings that were made in 1928-9, and the instructions to write about the great heroism and fighting spirit of the workers, may be seen as a reflection of the toughening attitudes of the international communist movement both towards its opponents and towards its national sections. ${ }^{53}$ These criticisms did not actually change the character of the stories although they may 
have added to the number of stories recounting the strength and positive achievements of the labour movement. The lone heroes, who during the second half of the decade became more common, gained their inspiration from the tradition of Finnish working-class literature but also from the adventure stories of popular fiction and Soviet communist literature. Soviet models could perhaps gain more ground during the two last years but a communist hero dedicating himself to the cause, overcoming obstacles and inspiring others to do the same was still not typical. The strongest evidence of communist inspiration was to be found in the stories of young men giving up their private lives for the cause.

Soviet stories of dedicated heroes paid attention above all to the development of the main character, leaving the circumstances as a matter of secondary importance. The Finnish labour movement had been accustomed to the opposite and was also in the 1920 s of the opinion that in a country where workers were not in power it was necessary to challenge the legitimacy of the authorities and the whole regime. Finnish communists in Finland accordingly gave these themes precedence, although the Finnish communists in the Soviet Union urged them to give more weight to the communist movement itself. They did so without great success, however, and in the course of the 1920s the attempt to turn the communists in Finland from critics and mockers to preachers was not to be achieved.

\section{Notes}

1. Jane Degras (ed.), The Communist International 1919-1943. Documents. Volume I 1919-1922. (London, 1956) pp. 259-65.

2. On the characterisations, see e.g. 'Liebknecht-Lenin', Itä ja Länsi, 15 January 1925; 'Kultainen kirje', Liekki, 21 May 1926; 'Lenin, vallan- 
kumouksellinen nero', Työväenjarjestöjen Tiedonantaja, 24 January 1927.

3. Geoffrey Hosking, Beyond Socialist Realism. Soviet fiction since Ivan Denisovich (London, 1980) p. 15; on the heroes in Soviet literature, see also Peter W. Mathewson, Jr., The Positive Hero in Russian Literature (Stanford, 1975) pp. 167-8, 179-251; Vera S. Dunham, In Stalin's Time. Middleclass values in Soviet fiction (Cambridge, 1979 (1976)) pp. 59-65.

4. Of the above-mentioned books the works of Gorky, London and Gladkov were translated into Finnish.

5. On the beginnings of Finnish communism, Tauno Saarela, Suomalaisen kommunismin synty 1918-1923 (Tampere, 1996).

6. On the communist literary magazines, Tauno Saarela, Postilla vai Nyyrikki? Suomalainen kommunismi ja lehdet 1920-luvulla', in Jouko Joentausta (ed.), Palstojen takaa (Helsinki, 1997) pp. 14-15; see also 'Taipaleelle', Liekki, 28. September 1923; on the earlier magazines, Aimo Roininen, Kirja liikkeessä Kirjallisuus instituutiona vanhassa työväenliikkeessä (1895-1918) (Vammala, 1993), pp. 11015.

7. See e.g. Tatu Väätäinen, 'Raatajan palkka', Liekki, 5 and 12 September 1924; Antero Virta, 'Tehtaan tytto', Liekki, 24 October 1924; Vesa, 'Koneiden uhri', Revontulet, 14 October 1927; Azlag Jarga (Emil Pyttynen), '"Kuropatki"', Liekki, 8 and 15 August 1924; 'Yli voimien', Revontulet, 18 November 1927; on logging in the Finnish literature, Jyrki Pöysä, Jätkän synty. Tutkimus sosiaalisen kategorian muotoutumisesta suomalaisessa kulttuurissa ja itäsuomalaisessa metsätyöperinteessä (Vammala, 1997) pp. 96-8.

8. See e.g. Anna Suonio, 'Katutytto', Liekki, 14 October 1927; 'Häätö, Liekki, 25 August 1925; Kirsti Violenti, 'Saajalahden huutolaispoika', Liekki, 16 November 1923; Simson, 'Tikkurenki', Liekki, 25 July 1924; Alex Orjatsalo, 'Raatajan palkka', Liekki, 11 January 1924; Veli, 'Uhraaja', Liekki, 6 June 1924; Pohjanpoika, Elämän armoton todellisuus, Liekki, 9 April 1926.

9. Kaarlo Valli, 'Käsipuolen tarina', Liekki, 29 July 1927; Ossi Ahtola, 'Rahaa, rahaa - leipää, leipää, Liekki, 21 March 1924; Lauri Kanto, 'Luisuvalla tiellä, Liekki, 9 October 1925.

10. Veli, 'Eräs joulu', Liekki, 21 December 1923; Lauri L., 'Laulajan tarina', Liekki, 15 February 1924. 
11. On working-class literature in Finland, Raoul Palmgren, Työläiskirjallisuus (Proletaarikirjallisuus). Kirjallisuus- ja aatehistoriallinen käsiteselvittely (Porvoo, 1965), pp. 165-6; on Finnish realism, Päivi Lappalainen, 'Epäkohdat esiin - Realistit maailmaa parantamassa', in Järkiuskosta vaistojen kapinaan. Suomen kirjallisuushistoria Toimittanut Lea Rojola (Helsinki, 1999), pp. 11-12.

12. See e.g. Yrjö M-la, 'Mitä ja miten on Liekkiin kirjoitettava?', Liekki, 23 May 1924.

13. Jeppe, 'Petiittinikkarin toilauksia', Liekki, 16 November 1928; 'Mitä lehdestämme sanotaan', Liekki, 4 January 1929.

14. Ludvig Kosonen, 'Proletaarisesta ja porvarillisesta taiteesta', Liekki, 2 August 1929.

15. Ludvig Kosonen, Ajopuita elämän virrassa', Revontulet, 14, 21 and 28 June, 5, 12 and 19 July 1929.

16. Ludvig Kosonen, Lippulaulu. Kuvaus Suomen kommunistisen nuorisoaktiivin elämästä vuodelta 1929 (Leningrad, 1932).

17. See e.g. E. Salometsä, 'Siellä missä kynttilät eivät loistaneet', Liekki, 21 December 1928.

18. See e.g. Veli, 'Pimeiltä poluilta', Liekki, 26 October 1923; Tikka, 'Iltamatyttö, Liekki, 28 March 1924; Antero Virta, 'Eeva', Liekki, 24 October 1924; Hely Haihtuva, 'Lautatarhan tyttö, Liekki, 30 January 1925.

19. See e.g. Vennu, 'Murhaaja tuomarina', Liekki, 14 November 1924; Anni Koffert, 'Kenen syy?', Liekki, 27 March 1925.

20. Aaron Kepulin liikeyritys', Liekki, 15 February 1929.

21. Veli Luokka, 'Suunnitelma', Liekki, 21 December 1928 and 4 January 1929.

22. See e.g., Tikka, 'Iltamatyttö, Liekki, 28 March 1924; Työläissisko, 'Oikealla tiellä, Liekki, 4 April 1924; Usko Varma, 'Suojelija', Liekki, 5 December 1924.

23. Lauri Kanto, "'Yhteiskunnalle vaarallinen"', Liekki, 4 February 1927; on the Socialist Youth League, Nestori Parkkari, Nuoret taistelun tiellä. Suomen vallankumouksellinen nuorisoliike 1900-1944 (Kuopio, 1970), pp. 132-6.

24. M.R.Y (Armas Äikiä), 'Pommi- ja dynamiittiliitto', Liekki, 24 June 1926; see also Maailmanrannan ylioppilas (Armas Äikiä), 'Suuri salaliitto', ltä ja Länsi, 30 November 1925. 
25. Pekka Paavahti (Ludvig Kosonen), 'Suurenmoinen paljastus kommunistien aseellisesta toiminnasta', Liekki, 10 May 1929; see also Kaarlo Valli, 'Ladatun helvetinkoneen hirveä salaisuus', Liekki, 1, 8 and 15 March 1929.

26. Tikka, 'Iltamatyttö, Liekki, 28 March 1924; Tikka, Veeran viha', Liekki, 6 June 1924; Inga, 'Nuoren taistelijan kokemus', Liekki, 29 August 1924; -o, 'Lailan särkyneet unelmat', Liekki, 10 July 1925.

27. See e.g. Hellä Kotijärvi, 'Elämän ulapalla', Liekki, 7, 14, 21 and 28 March, 4, 11, 18 and 25 April 1924; Maiju, 'Hotellin tiskityttö, Liekki 25 February 1927; Iikka Kare (Otto Oinonen), 'Erään tytön muistikirjasta', Liekki, 30 September, 7, 14, 21 and 28 October, 4, 11, 18 and 25 November, 2, 9 and 16 December 1927.

28. Ossi Ahtola, 'Rahaa, rahaa - leipää, leipää, Liekki, 21 March 1924; Maailmanrannan ylioppilas (Armas Äikiä), 'Työmies Rissasen loppu', Liekki, 21 August 1925.

29. A. Eronen, 'Työlakko', Liekki, 11 September 1925.

30. Kaarlo Valli, 'Leipää - oikeutta', Liekki, 30 September 1927; A.E., 'Taistelu leivästä, Liekki, 10 February 1928; Taistelijatar, 'Kaksi tunnelmaa', Liekki, 19 October 1928, A. O-lo, 'Joko - tahi', Liekki, 3 May 1929.

31. Pirjo Ala-Kapee - Marjaana Valkonen, Yhdessä elämä turvalliseksi. SAK:laisen ammattiyhdistysliikkeen kebitys vuoteen 1930 (Helsinki, 1982) pp. 718-29.

32. Iikka Kare (Otto Oinonen), 'Kumpusaaren kesävieraat', Liekki, 20 July 1928.

33. Kalle Rissanen, 'Solu', Liekki, 17 and 24 September, 1, 8, 15, 22 and 29 October, 5, 12 and 19 November 1926.

34. Palmgren, Työläiskirjallisuus, p. 151.

35. See e.g. Kaarlo Valli, 'Viimeiset laukaukset', Liekki, 3 September 1926; Kaarlo Valli, 'Yksi monista', Liekki, 22 July 1927.

36. See e.g. K. K-o, 'Yhdennellätoista hetkellä, Liekki, 25 April 1924; Are L-n, Kotitarkastus', Revontulet, 10 September 1926; Aatto Lahtio, 'Takaa-ajettuna', Revontulet, 8 October 1926; Risto Karu, 'Marusja', Revontulet, 23 September 1927; Maailmanrannan ylioppilas (Armas Äikiä), 'San Juan alkuasukaskommunisti', Liekki, 21 January 1927.

37. See e.g. Henriks D:son (Kyösti Kivi), 'Työläisluokan nuoriso ja laiskuriluokan ajanvietekirjallisuus', Liekki, 5 June 1925. 
38. K. Brown-Wolf (Kyösti Kivi), Varastettu valtionhoitaja, Liekki, 22 and 29 January, 5, 12 and 19 February 1926.

39. On this kind of popular fiction, see e.g. Timo Kukkola, Hornanlinnan perilliset. 70 vuotta suomalaista salapoliisikirjallisuutta (Porvoo, 1980) pp. 64, 78-80.

40. 'Kapinaromantiikkaa', Itä ja Länsi, 15 October 1924.

41. Azlag Jarga, "'Humu"', Liekki, 4 March 1927.

42. Armas Äikiä, 'Apusahuri', in Työläiskynäilijäin ja kuvaajain liitto Yhteisvoiman albumi I (Helsinki, 1929), pp. 29-33.

43. Eino Kataja, Olavi Borglund, Liekki, 15 June 1928.

44. See e.g. Mildred Cram, 'Musta silkkinuora', Revontulet, 19 and 26 November, 3 December 1926; 'Rakkaustarina Etelämeren saarilta', Revontulet, 31 December 1926; Stacy Aumonier, 'Rakkaus vaiko kuningaskunta', Revontulet, 6 and 13 May 1927; 'Ruhtinattaren lemmentarina', Revontulet, 8 July 1927; 'Filminäyttelijättären rakkaus', Revontulet, 10 August 1928.

45. Usko Varma, 'Onnen kukkanen', Liekki, 22 December 1924.

46. Veli, Voimakkaita tunteita', Liekki, 15 February 1924; I.N., 'Saavuttamisen arvoinen ystävyys', Liekki, 20 February 1925; Tikka, 'Toveruus ja rakkaus', Liekki, 6 March 1925; Anna Suonio, "Anna minun olla toverisi"', Liekki, 2 March 1928.

47. Iita Nuotio, 'Kukkivien tuomien alla', Liekki, Midsummer 1925; Kyynelten lemmikki, 'Mökin Johanna', Liekki, 30 April 1926; Marit Matkakoski, 'Tyttö potkukelkassa', Revontulet, 4 November 1927.

48. Ludvig Kosonen, 'Ajopuita elämän virrassa', Revontulet, 14, 21 and 28 June, 5, 12 and 19 July 1928.

49. See e.g. Azlag Jarga, 'Kaksi ihmistä, Liekki, 2 and 9 May 1924; Ida Hagert, 'Aatteen vuoksi', Liekki, 15 August 1924; Hemmi Aro, 'Oman luokkansa lapsia, Liekki, 10 October 1924; Aarne Linnansaari, Nukkuva kaupunki, Revontulet, 16 April 1926.

50. See e.g. Anna Suonio, 'Paulan taistelu', Liekki, 22 July 1928; E. L. Suksi, 'Sosialistipuhuja', Liekki, 24 May 1929.

51. Iikka Kare, 'Takaisin maankamaralle', Liekki, 22 and 29 June, 3 July and 3 August 1928; Taistelijatar, 'Uskollinen vakaumukselleen', Liekki, 31 August 1928; Risto Karu, "'Muista kuka olet!', Liekki, 19 October 1928. 
52. On the love stories, Ulla Eloranta, "'Villiorvokkien huuma". Naistenviihde populaarikulttuurin kentässä, in Aika on aikaa...Tutkielma poploresta. Toimittanut Seppo Knuuttila (Helsinki, 1975), pp. $166-8$.

53. On the earlier discussion, Aimo Roininen, 'Työväenliike tuo työläiset kirjallisuuden kentille', in Järkiuskosta vaistojen kapinaan, p. 101. 


\section{Finnish communist youth and popular music, 1944-1969}

The autumn of 1944 indicated a new beginning for Finnish communism $^{1}$ as the Communist Party of Finland (Suomen kommunistinen puolue, SKP), which was founded in Moscow in August 1918 by the Reds who had escaped to Soviet Russia after the abortive revolution in Finland and which had been a prohibited party in Finland and had had its headquarters in Soviet Russia/ the Soviet Union since its foundation, emerged from the underground. On the other hand, People's Democratic League of Finland (Suomen kansan demokraattinen litto, SKDL) was founded as a new organization left of the Social Democratic Party (SDP) by the communists, socialists and left social democrats. In a way the SKDL continued the traditions of the Socialist Workers' Party of Finland (Suomen sosialistinen työväenpuolue, SSTP) and the Socialist Workers' and Smallholders Electionary organizations which had been able to work in public in the 1920s.

Despite it difficult past the movement was committed to Finnish society and its questions as proven by the success of 23.5 percent of the votes in the parliamentary elections in March 1945. Its support remained over 20 percent up to the end of the $1960 \mathrm{~s}$ and over 15 percent during the 1970s. In 1945 the SKDL became an important force in the coalition government with the Social Democratic Party and the Agrarian Party. The co-operation was not on a strong base, and the SKDL was ejected from the government in the summer of 1948. It returned in the government in 1966 and participated in the coalition governments throughout 
the 1970s. That reflected the acceptance of the movement as a Finnish movement.

The Finnish communist movement carried various traditions. Those who had lived long periods in the Soviet Union or got educated there had committed themselves to the communist ideology and practices as interpreted by the Russians and the Communist International. Those who had lived in Finland and been active in the legal organisations of the 1920s had also become acquainted with the communist doctrine but formulated their politcs mainly on the basis the traditions of the Finnish labour movement and situation in Finland. The ideological and political sources of those who had joined the social democratic associations and trade unions in the 1930s included, besides traditions of the Finnish labour movement, also ideas of left socialists in the Second International and the European left socialists in the 1930s.

The past of the movement was characterised by political, cultural and ideological struggle of the values, organisational forms and modes of behaviour in the Finnish society. That cultural struggle was also deemed important in the SKDL as the cultural programme of the party, published in 1947 as the first programme of the movement, proved. The intention of the programme was to outline tasks in order to change "the nationally narrow-minded, chauvinistic, religiously intolerant and warmongering" cultural system which had had a strong position in Finland during the inter-war years. The SKDL set as its ideals the great humanity of the labour movement, the brotherhood and equality of people and nations but also the best progressive traditions of the Finnish national culture. ${ }^{2}$

Music did have a role in this cultural struggle. During the 1920s that had manifested above all as attempts to ward off the new forms of popular music, especially jazz and dances connected with it. This negative attitude reflected the commitment of the Finnish labour movement to the ideas of popular enlightenment; the task was to root out the habits of the working people considered notorious and inferior and to make them involved in the 
activities of the high culture. The latter also reflected the democratization demands of the movement. The attitude also reminded of the strong commitment of the Finnish labour movement to the temperance movement; jazz was connected with restaurants and alcohol and therefore considered bad. It was also usual in the communist movement to regard popular culture as an activity to strengthen, not to challenge the existing system. ${ }^{3}$

The same attitude continued in the SKDL. The esteem of high culture was probably strengthened as some of the active intellectuals in the SDP in the 1930s joined the movement. The example of the Soviet music policy - music modelled on folksongs or city folklore and its evaluation according to the criteria of the art music - would also contribute to the same direction from the late 1940s. The changes of political situations in the world and in Finland would also have an impact on the assessments of the music.

The cultural programme stated that "bad, standardized music played by dance bands and restaurant gramophones have spoilt the music taste of the people, while determined platform and practical presuppositions to spread knowledge of good music everywhere had been missing." 4 The definition of "good" and "bad" music was not quite clear in the programme, but in the late 1940s and early 1950s it became evident that "good music" included solemn labour hymns and battle songs, which were important for ideological and political reasons, but also folk music and art music with beautiful sounds. Bad music included dance pieces, "graceless jingle-jangle", music in restaurants, revue songs, American pop songs, lecherous pop songs. Thus it was connected with voluptuous entertainment, Western decaying culture or bourgeois political revue, which had been evolving from the late 1940 s and defined on political and moralistic grounds. ${ }^{5}$

In the 1920s the youth of the movement had partly joined the negative assessments on popular music but also taken advantage of the new music in order to promote its own message. It was also played in the dances organised by the local associations in their labour halls. In this article I try to analyze how the youth of the movement, the Democratic Youth Union of Finland (Suomen 
demokraattinen nuorisoliitto, SDNL), was disposed to popular music.

Jazz

Immediately after the WWII American music symbolized the cooperation and common struggle of the war years. Even in Finland the city youth had demonstrated an interest towards swing during the war years. That was also reflected on the pages of Terä, the organ of the SDNL. The first sample of the weekly promised articles for the friends of jazz and welcomed the idea to publish English texts of some successful songs. ${ }^{6}$ The promise seemed to become true as the second sample published the English words of I'm getting sentimental over you, the famous Tommie Dorsey orchestra presentation, and later articles on the background of jazz, the development of jazz orchestras and jazz terminology. It also crowned Louis Armstrong as the "king of the trumpet".

At the end of the summer these articles, however, disappeared. That was probably due to the quick development of the SDNL which contributed to the fact that the news telling of the foundation of new associations filled the pages of Terä. But the opponents of jazz had also their role; some persons in the union were afraid that the youth might adapt a certain swing mentality, that the dance would become excessive in their lives and make the youth neglect education and other important aspects of life. They warned that an inordinate interest in swing would lead to spiritual emptiness among the youth. In order to make their warning heard the opponents of swing claimed that Terä was becoming the organ of the jazz enthusiasts. ${ }^{8}$ These opinions obviously knocked down those who explained that all the progressive youth movements in Europe and America paid great attention to modern dance music. Their attempts to regard the disagreement as that of the generations and arguments that swing could not be more harmful for the moral than waltzes or polkas the older gen- 
eration used to dance did not prevent the disappearance of jazz on the pages of Terä. ${ }^{9}$

Thus the attempts to break the traditions did not succeed, but the moralizing aspects of the movement's past got priority. That was, however, not the only cause. The enthusiasm for jazz was also drowned by the Cold War and the Anti-Americanism accepted in the Soviet Union and the international communist movement ${ }^{10}$. On the pages of Terä this Anti-Americanism was above all presented as criticism towards the decaying effects of American films and light reading, especially detective stories. Music was forgotten, and there were only a couple of articles which repudiated jazz on the pages of Terä in the late 1940s. ${ }^{11}$

The beginning of the Cold War had also more indirect effects on the musical orientation of the SDNL. In its search for a proper youth music the SDNL found the examples of the bourgeois youth associations in Finland and the performance groups of the "socialist" countries which visited Finland in the early 1950s worth following and urged its associations all over the country to establish folk dance groups. Their performances became a significant part of the events organised by the SDNL. This folk dance interest was supposed to reflect the "genuine" and "pure" folk culture. The folk dances continued to be an important part of the union's festivities up to the mid-1960s. ${ }^{12}$

Folk dances were obviously not enough for all the members in the SDNL; jazz made its comeback on the pages of Terä, now a monthly, in the mid-1950s. The same questions whether jazz was acceptable or not puzzled still the articles published in the magazine. The attitude towards jazz was, however, different from the years immediately after the war when jazz - or swing - had been valued as a dance music favoured by the modern youth. In the mid-1950s jazz was consciously separated from dance music and youth culture and regarded as music to be listened. The youth was to be taught to separate real jazz from the mass music which was born as "an undergrowth of jazz". That was done in Terä by a series of articles on the history of jazz from New Orleans to bebop. ${ }^{13}$ 
These articles were guided by Anti-Americanism but they also had a tinge of Marxist explanation of how the changes in the economic life and in the US foreign policy had influenced the development of jazz. Accordingly, the golden age of jazz which had started in New Orleans at the end of $19^{\text {th }}$ century, had ended during the Great Depression. Swing, the new style of jazz born in the mid-1930s, reflected the optimism of the recovering economy. At the same time jazz was also turned to merchandise by the entertainment industry. That was the main reason the whites started to get interested in jazz and pushed black musicians aside. The optimism of swing died during the Cold War which, according to the writer, had blown "the refrigerator spirit" into the jazz. Besides, the United States used jazz as a means of its foreign policy and attempted to get the jazz listeners consider American way of life good.

The writer did not hide his enthusiasm for classical jazz played before the swing era. For him, bebop, the jazz style born in the 1940s, represented the deepest decay of jazz; it was "cacophony", its "rhythm was limping and its melody did not obey any laws in respect of sounds or tones." But there was also a certain tendency in his assessments to see jazz as blacks' music and consider jazz played by black musicians as good, and that of the whites as bad and commercialized. Thus, in spite of his negative words on bebop, the writer valued Charlie Parker and Dizzy Gillespie but belittled Gerry Mulligan and Stan Getz, the representatives of cool jazz, as "trivial musicians". According to him, white jazz was in general spiritless and lacked the original power of jazz. He, however, admitted that there had been such good white jazz musicians in the swing era as Benny Goodman, Artie Shaw, Glenn Miller and Bob Crosby but he regarded Harry James's presentations as lifeless and Stan Kenton's as "emotionless and machinelike".

The negative aspects and the last remnants of Anti-Americanism disappeared, or at least diminished, as the contextualization of jazz changed from the economic and political development of the United States to that of music and its own history. Thus, in an article series published in 1957 various styles of jazz were studied 
mainly in relation to improvisation. While a group improvisation dominated in the old New Orleansian style, in Chicago that was replaced by solo improvisations. In the late 1920s and 1930s the role of the improvisation, however, diminished, and disappeared almost entirely in swing. The writer saw this development in connection with the sound film. Hollywood also furthered the vulgarisation of jazz and its identification with dance music. ${ }^{14} \mathrm{He}$ had also given up the negative assessments on modern jazz "as dissonance music", and was content to present musical changes - the improvisation increased and various instruments got more free room, the rhythm became more complicated and more difficult to understand, jazz was separated from dance and became music to be listened. The writer did not accept the notion that jazz was in crisis with the experimental development but saw all the styles of jazz developing full of life. ${ }^{15}$

Terä did not entirely give up differentiation between good and bad jazz but did not do that in earlier moralizing tones but advised its readers to listen to those musicians the American jazz magazine Down Beat had elected as best musicians. ${ }^{16}$ The lists of Down Beat did obviously influence the assessments - at least there were no signs of negative criticism towards Gerry Mulligan and Stan Getz as in $1955^{17}$. Not even the fact that many famous jazz musicians had problems with drugs or alcohol was met with great disapproval, even though they were recognised as a great danger for creative artists who had to balance with creative improvisation and constant performances. Terä, however, emphasised that drugs did not improve the level of music. ${ }^{18}$

The return of jazz on the pages of Terä was not self-evident in the mid 1950s. In the SDNL there were still persons who did not want Terä to publish articles or reviews on jazz. These persons were worried that along jazz and Hollywood the magazine would become similar to commercial light readings advertising the American way of life. Some of the opponents reminded that jazz was fashionable only among the city youth, especially among college boys, which were a tiny minority within the readers of Terä. Jazz was also a foreign import, and the folk music of Ameri- 
can blacks would not get a solid foothold in Finland. They wanted Terä to concentrate on national and other international music. ${ }^{19}$ Their opinions also reflected the esteem of high culture:

The great thinkers of the mankind have declared noble spirituality, proud heroism, and that is described by Beethoven in his Eroica. The sweaty sexuality of modern dance music and the hollow whimpering of the saxophone are quite different. Culture includes Schiller's poems and Dostoyevsky's prose, but not sentimental pop songs or brutal westerns. Culture is Shakespeare's dramas, Verdi's operas and Soviet ballet, but not French cabaret, Cole Porter's operettas or can-can. ....

Culture is born in the smell of grass and earth.... It includes the folk songs of great rivers and the negro spirituals of Mississippi, but not the barrooms in New Orleans. ${ }^{20}$

Even though the editors of Terä admitted that there had been much more articles on jazz compared to other music on the pages of the magazine, the propositions did not change as a new disc column Bachista be-bopiin (From Bach to be-bop) was started in Terä in the beginning of 1958 . The intention was to present shortly discs worth listening ranging from symphonys and operas to jazz, but in 1958 the emphasis was on jazz. Within jazz bebop and cool got a larger share, but many musicians and discs of the traditional jazz were also highlighted. There were also attempts to present European, mainly British, Swedish and Dutch, jazz, but Django Reinhardt and the Quintette du Hot Club de France did not show up. ${ }^{21}$

Although the comeback of jazz on the pages of Terä indicated a break with the earlier attitudes and indicated that jazz had achieved an acceptable position within the SDNL, many articles of the magazine hinted that art music was still at the top of the hierarchy. Jazz, however, lost its importance in the music column of Terä as the dance music got priority in 1959 and also the reference to jazz in the name of the column vanished. ${ }^{22}$ The jazz concerts of the great names of the jazz which took place in Helsinki in the early 1960s, were sometimes reviewed in $\operatorname{Terä}^{23}$ but in 
general jazz was not anymore advertised with such an enthusiasm as in the late 1950 s.

\section{Dance music}

The attitude towards schlagers and pop songs was initially also contradictory, and they were looked throught the glasses of high culture and Anti-Americanism. That became evident in the discussion on the music of Georg Malmstén, one of the most influential singers and composers in the Finnish light music from the late 1920 s up to the $1940 \mathrm{~s}^{24}$. Malmstén, who had had a visible role in the entertainment activities during the war, had lost his status in the late 1940s, but his $25^{\text {th }}$ artistic anniversary in 1953 gave a reason to touch his music. For the writers in Terä, Malmstén's career in the service of light music was a proof of how musical talent was wasted in the society based on the power of money. On a proper education Malmstén would have become a good opera singer. All the assessments reflected the high esteem of high culture in the movement, but there were different opinions on how the aspects of Finnish folk culture and Anti-Americanism were combined in Malmstén's music. Some of the writers defended his waltzes, foxtrots or polkas as melodic with Finnish tinges or as Finnish dance music, while some claimed that his music was American in regard to its melody and sweet lyrics. ${ }^{25}$ There was a tendency in the leadership of the SDNL to accept popular music which was not closely connected with American youth culture. ${ }^{26}$

Esteem of high culture and Anti-Americanism characterised also the attitude of the SDNL towards various dances in the early 1950s. Terä was concerned that the youth would dance properly and gave dance lessons on its pages. The magazine favoured traditional dances and was initially skeptical about new dances. Boogie-woogie, for instance, was only "gyrating and stamping feet with an artificial laugh at one's face", and it was characterised as "a combination of the existentialism of Montmartre and dance originating from the United States". Jive was, however, welcomed 
in 1955, and in 1957 it became part of the cultural contest of the SDNL. ${ }^{27}$

In the late 1950s schlagers and pop songs got more room in Terä; the magazine published an article with plenty of photographs on the Finnish pop song contest in 1957 and the female winner of the contest in 1958 portrayed on the cover of Terä in January $1958 .{ }^{28}$ Pop song became also part of the cultural contests of the SDNL, first in Northern Häme in 1957 and next year in the whole country. Some interviews or articles of international singers also found their ways on the pages of the magazine at the end of the 1950. Through these articles Terä obviously wanted to point out that light music was not only presented in the AngloAmerican world and to emphasise the many-sidedness of the interviewed singers; the Swede Alice Babs was known of her jazz songs but sang also Swedish folk lore and opera, the Estonians Kalmer Tennosaare and Harry Vasar were, like their much more known countryman Georg Ots, used to sing anything from operas to light music, Yves Montand was besides popular singer an active member of the Communist Party of France, Harry Belafonte was "Calypso king" but also a well-known advocate of civil rights - in this sense he followed the footsteps of Paul Robeson on the pages of Terä. ${ }^{29}$ This "internationalism" disappeared in the early 1960s, but there still was a certain tendency to emphasise the interest of the interviewed Finnish pop singers in jazz and other music. ${ }^{30}$

There were also attempts in Terä to lift the position of schlagers or pop songs by claiming that they were not necessary mere dance music or outbursts of passions created by sexuality - the intention of the pop songs was to create images of harmony and fulfilled satisfaction. The presentation of modern dance music also required as special skills as that of art music. Plagiarism which was closely connected with commercialism had, however, spoiled the originality which was needed in good pop songs, too. ${ }^{31}$

Although pop songs became acceptable in Terä in the late 1950s there was a music style it did not tolerate - rock and roll. In a way the acceptance of jazz was paralleled by finding a new 
enemy - rock and roll. Although rock and roll's origin was different from that of jazz, in Terä it was regarded as a kind of decaying jazz, and labelled as "commercial travesty of jazz". According to the writers, good jazz musicians knew how to play their instruments, while the peddlers of rock and roll claimed that all you had to be able to do was to clap your hands in rhythm and wiggle your legs. Elvis Presley and Bill Haley were assessed of not being able to read music or play quitar properly, and Elvis Presley's singing was roaring and gave the listener only headache. It was, however, the movements of the rock singers and guitarists that were considered most displeasing and vulgar. Rock and roll was mocked as "the result of the marriage between jitterburg and tsetse fly." One writer went as far as to claim that those who listened to rock and roll became nothing good, not university students or customers in libraries. ${ }^{32}$ Rock and roll was, however, mainly kept outside Terä.

Rock and roll was not the only style that was left outside Terä. In the early 1960s almost all the international music disappeared from the music column of the magazine, and it started to concentrate on Finnish dance music, that is waltzes, tangos, humppas, a Finnish version of foxtrot, but also jenkas and polkas. ${ }^{33}$ The increase of pop music on the pages of Terä was obviously due to the fact that it was the music that the editor of the music column favoured. But it also was the music the working class youth and the majority of the SDNL members listened to and danced in the dance organised by the communist associations in labour halls. It also reflected a more general musical trend; there was a great tango boom in Finland in the early $1960 \mathrm{~s}^{34}$. But the boom was also changing as the pop and rock music originating from Great Britain and the United States properly landed in Finland during the 1960s. 


\section{Rock music}

The year 1966 indicated a prominent increase in the amount of pop music on the pages of Terä. That was partly due to the fact that the new and younger editors of the magazine realised the importance of pop music in the lives of the generation born after the WWII. And that was mainly due to the fact that pop music conquered the world via radio and television but also via festivals and concerts. Even in Finland the possibilities to listen to English and American bands improved. Many of the rock concerts were organised at Kulttuuritalo, the headquarters of the Communist Party of Finland. That was not due to the appeal of the communist movement but the good acoustics of the fest hall and due to the willingness of the owners of the house to hire its premises to concert organisers. ${ }^{35}$

In the mid-1960s the music column of Terä became more diversified; besides old Finnish dance music, it presented new Finnish pop songs, protest songs and experimental music but above all English and American rock music. The Renegades, a Birmingham band, which spent the years 1964-65 and also recorded in Finland, was recognised in the beginning of 1965 as Cadillac, the band's hit, reached the top of the lists. ${ }^{36}$ It was, however, only in 1966 that the records of English and American bands and singers got more room in the presentations of Terä. ${ }^{37}$ The changes included more interviews of young singers. These interviews betrayed a certain interest in folk music, especially in its Finnish representatives. ${ }^{38}$ The enthusiasm for folk music included also presentations of some records by foreign folk singers. These presentations revealed that the music critics of Terä preferred Donovan to American singers and did not understand the reputation of Bob Dylan. ${ }^{39}$

In 1966 there were also some presentations of blues in Terä. The writer went as far as presenting blues as "one of the few really socialist art forms in the world". That indicated a song tradition that was popular and daily among the American blacks. The songs consisted of propaganda, social history, and sad, joyful, angry and 
sentimental stories of life, love, race feelings, crimes, daily concerns, and criticism. ${ }^{40}$ Later on the magazine referred seldom in original blues ${ }^{41}$, but comparison with it became a strong criterion for acceptance of rock records in the magazine. Spencer Davis Group was, for instance, praised for having preserved the original rhythm of blues ${ }^{42}$; John Mayall and the Bluesbreakers, who visited Helsinki in the summer of 1967, was praised for "having found the black essence of the Afro-American popular music as well as Django Reinhardt, the great French quitarist". 43 "Cultivated whiteness" on the other hand could leave the listeners cold. ${ }^{44}$

Referring to the origins did not, however, become the dominant characteristics in the presentation of rock music. Eclecticism was not appreciated by communists but on the evaluation of rock music in Terä eclecticism became an asset. In 1967 the magazine published an article by Risto-Juhani Suokas, an electrician with strong interest in cultural questions. In this article pop music was touched in relation with the classical music. The article also suggested a step away from a notion that pop music would only be music easily used and accepted. Along the more traditional line Suokas emphasised the importance of the lyrics, and how pop music presented opinions of the events in the world. More important, however, were his ideas that pop music used rich sound and melody structures, which were close to the Baroque music, but also new electronic sounds, which reminded of concert music. These and the use of Oriental and African instruments indicated that pop music could assimilate various styles and thus create bridges to the music which was traditionally valued by the audience. ${ }^{45}$ Thus the appreciation was, in a way, connected with the esteem of art music in the movement.

These became also the criteria for Ilpo Saunio, the music critic of the magazine, to evaluate bands and their music; the guitar sounds originating from blues were connected with Indian, African, electronic, historical, folk lore colours. According to Saunio, the rock bands had resurrected the vaudeville, the playful and ironic musical, which used well-known and popular strains. Besides vaudeville the British bands, for instance the Beatles and the 
Kinks, took advantage of the nursery rhymes tradition. On that basis Sgt. Pepper by the Beatles was regarded as a step towards a phase when pop music could not anymore be called as "mere entertainment", because it was made with as great calculation as any work of modern classical music. It was also as artistic. Ilpo Saunio praised Sgt. Pepper's music as many-sided; he did not hide his enthusiasm for the use of sitar and other oriental instruments but he also praised the use of swing in When I'm sixty-four and 'genius baroque guitar solo in the beginning of Lucy in the sky with diamonds. ${ }^{46}$

According to Saunio, the Beatles were children of culture and civilization, of the European Faustian world view, while improvisation and rhythm were the sources of Jimi Hendrix's strength. The Beatles made composed music, while Hendrix created elemental, original ritual music which reached the audience rather through physical than intellectual influence. Thus, Hendrix was at the concert "a volcanic, completely original and inimitable force of nature", but on the record his music, compared to the Beatles, could sound robust, monotonic and unconsidered ${ }^{47}$ Saunio, however, valued highly the albums of Jimi Hendrix Experience and their "endless guitar sounds winding like garlands".48

Saunio was, however, quick to realize that concerts were becoming less important than the discs. At the end of 1967 he went as far as to regard listening of pop music albums as the most important work of a music critic because the most avantgarde music of the moment was presented in them. Therefore the concerts of the bands were not anymore as important as the discs, although there were exceptions; the Cream had, according to Saunio, not presented as courageous and well on its records than in its concert in Helsinki. The emphasis on disc production was due to the fact that the bands had exhausted the normal means of the guitar music. On records it was possible to use other instruments and technical devices in order to revise the sound. Thus, the pop music was started to regard as art, it started to adapt the criteria and characteristics of classical art music, of which the most important 
was the breadth of composition; the albums were intended to be listened without intervals. ${ }^{49}$

It became important for Saunio to draw a parallel with some pop records and avant-garde classical music - Saunio had launched John Cage's ideas in Finland ${ }^{50}$. Thus Absolutely free by Mothers of Invention was considered similar to John Cage's music, ${ }^{51}$ Sing This All Together by the Rolling Stones was music from a strange planet - just like Karl-Birger Blomdahl's space opera Aniara. The beginning of 2000 Light Years from Home by the same band was "pure electronic music á la Darmstadt school." 52 The sounds Jimi Hendrix achieved by means of contact microphones and amplifiers reminded of Karlheinz Stockhausen's recent works Mikrophonie and Rezession. Besides these, Hendrix and Stockhausen were united in the esthetics of "ugliness". ${ }^{33}$

Although the interest in folk music in the mid-1960s had indicated the importanceof the message of the songs, the records were not often valued on the basis of their lyrics. In some occasions the words of Finnish pop songs were, however, criticised for being consciously created for "the audience under the average, the audience of a kiosk in the center of the village." In some songs the lyrics could be "so perfectly non-existent that it was difficult to find even values or characteristics typical for popular music." Even in some protest songs the lyrics were mocked of being "half pitying and only half social criticism." 54

Interviews of pop singers and presentations of records were not the only way to determine good music. By publishing occasionally statistics of the best selling records in Finland Terä also gave room for a more general opinion of the youth on music. ${ }^{55}$ The magazine also published results of the local top tens in which the voting was organised by the local communist youth by playing the records they had or could get from the local music shops for an audience. These lists reflected certain differences; the northern and eastern youth was for more traditional Finnish dance music, while the youth in southern towns was for the English and American rock. The difference could reflect the collections of the local music shops. ${ }^{56}$ 
The presentation of rock and pop music came to an end in March 1968, as the publication of Terä had to be closed down due to financial problems. As Terä restarted in 1969 popular music was not anymore important for the new editors of the magazine - then Terä spoke about economic interests of the working youth, imperialism, marxism-leninism, party theory and the achievements of the so called socialist countries. ${ }^{57}$ The change was not due to the older generation in the movement, although Tuure Lehén, Comintern's former adviser on military matters, commented the early rock music in his witty style: "I would be crazy about this guitar music, if my eardrums were of bull's skin." 58 The change in the content of the magazine was due to the change in the attitudes of the youth; the cultural left radicalism was not enough, a proper orientation along the marxist labour movement was needed.

\section{Kisällilaulut}

For the SDNL the popular music was not only jazz, rock or dance music. Various performing activities formed a great part of the activities in the SDNL from the very beginning. The performances of the singing and reciting groups were considered an efficient way of awakening the interest of youth and recruiting new members. In the numerous festivities of the movement there was also need of performances of these groups. Thus, the SDNL boasted of 738 groups in 1947, of 923 in 1949. After that the number declined; in 1955 there were only 525 groups, and 3800 persons involved in them. Of these performing groups the kisällilaulu ${ }^{59}$ groups were very popular, and there were 348 of them in 1947 and 410 in $1949 .{ }^{60}$

The kisällilaulu groups had their origin in the performance or agitprop groups which were born in the international communist youth movement at the end of the 1920s. In Finland these groups had been a mixture of influences from Soviet Blue Blouses, German and Swedish cabaret but also from the performance groups of the earlier Finnish labour movement. Their programme con- 
sisted of songs on contemporary political topics which touched the injustices or the defects of the existing society but also ridiculed and mocked political opponents, especially social democrats. The lyrics were very often arranged to the existing music, mainly on light popular songs, folk songs, revue songs, operettas, popular dance tunes but also some solemn patriotic songs. ${ }^{61} \mathrm{Al}-$ though the activities of the communist movement were forbidden in Finland in the summer of 1930, this kind of performance groups continued their existence as the social democratic youth influenced by the Swedish organisation took them as their own form at the end of the 1930s. ${ }^{62}$

Kisällilaulu groups were very similar to their predecessors; they were usually constituted of 5 to 7 singers and an accompanist with guitar, accordion, mandolin or banjo; it was necessary to form only boy or girl groups, mixed groups were forbidden; they also commented contemporary events of political life in their songs, and the melodies they used in their songs were wellknown folk songs, revue songs and dance music or pop songs. ${ }^{63}$

As the kisällilaulut formed an important part of the message of the youth movement, even the leadership of the Communist Party paid attention to the melodies and lyrics. Aili Mäkinen, the secretary in charge of propaganda in the SKP, advised the groups to use folk songs because they were art created by the working people. On the other hand the groups should avoid "less artistic pop songs", which were "flowers of a decaying bourgeois culture" and as such forced their ways into the minds of the working youth. According to Mäkinen, it was absolutely necessary to forbid the presentation of all the songs making fun of drinking or mocking the characteristics of genders or various peoples, to say nothing of presenting obscenities in the festivities of the youth union. Mäkinen obviously thought that Alfred Tanner's revue songs presented all that as she ended her recommendation by saying that his songs had very little to offer for the labour movement. ${ }^{64}$

In the 1940s the songs of kisällilaulu groups were mainly arranged to folk songs. The interest of the SDNL in folk dances did not increase the popularity of folk songs in the 1950s, but during 
the decade the amount of dance music grew considerably. Of the Finnish dance music especially jenkkas were common which was due to their popularity in the old Finnish dance music but also to their stereotyped melodics which created good basis for rhyming. During the 1950s there was, however, a tendency that the melodies were picked up of those pop songs which were in fashion, and the musical basis of the songs of the kisällilaulu groups followed the general development of pop songs quite closely. ${ }^{65}$ Thus the European pop songs which were popular in Finland in the late 1950s and early 1960s became common in the melodies of groups. From the mid-1950s the music originating from the United States, even the much-maligned rock and roll, found its way to the melodies of the groups, and the imitation of American youth culture by Finnish youth was mocked along the tunes of Rock around the clock by Bill Haley ${ }^{66}$ Thus the groups made those melodies known and perhaps even acceptable among the supporters and members of the SDNL.

Kisällilaulu was in many ways a product of the period of a separate working class culture and of a period when it was easy to find distinct enemies. This was changed in Finland in the 1960s as the communist movement got out of the long isolation and as the international tension was eased. This indicated the disappearance of the traditional political enemies. In the late 1950s and early 1960s the groups and their performances started to lose their spontaneity and to become formal. This was reflected in the younger generation of the SDNL which started to complain about the inward-looking character of the whole organization. The strong interest of Terä in rock music during the mid-1960s was also an attempt to get rid of kisällilaulut and to get involved with the youth culture in general. ${ }^{67}$

That was widely accepted, but in 1969 Terä published an article which longed for a comeback for the kisällilaulu tradition which, however, would have to get a new political content. The writer longed for such propaganda and agitation groups which would make the young workers and students to become aware of their social position. ${ }^{68}$ In the 1970s such singing groups started 
to appear, but their songs were not anymore arranged according to other melodies but composed themselves their songs or sang politcal songs from other countries. The songs did not anymore concentrate on mocking political opponents, but became closer to traditional and solemn labour songs. The new groups also paid much more attention to the artistic quality of the performances than the kisällilaulu groups. Due to the inner disagreements in the communist party and the whole movement and the practical division of the movement in two rivalling parties, the 1970s was a decade of orthodoxy when the commercial mass culture, especially the American, was once again condemned. ${ }^{69}$

In its attitude towards popular music after the WWII the Finnish communist youth was loyal to its bipartite tradition; on one hand there were those who condemned the popular music, on the other some regarded it as an integral part of the youth movement. According to the tradition, the movement also attempted to create its own popular music as the Kisällilaulu groups demonstrate. Despite the popularity of the Kisällilaulu groups, the communist youth also had to decide of its attitude to music with a foreign origin, that is, jazz, dance music, pop music, and rock and roll.

Popular music was often defined as bad music on the basis of its Anglo-American origin and especially on the basis of its relation to American imperialism or commercialism. During the late 1940s and early 1950s the idea of the world being divided into two hostile camps, promoted by the Soviets, gave the basis to consider jazz as bad influence, but gradually the latter aspects received a stronger position, and jazz performed by black musicians was first accepted as non-commercial jazz and jazz in general during the late 1950s. By that time even the more traditional concerns of jazz's low value compared to the works of high culture disappeared.

Rock music was indirectly criticized as a phenomenon of American imperialism, but criticism towards rock musicians' 
movements on the stage and their ability to play their instruments were much stronger. Thus the attitude to the rock music at first included moralizing tones of popular enlightenment, which was typical also for other political groups in Finland. That attitude, however, disappeared among the communist youth during the mid-1960s.

In several occasions the communist youth attempted to emphasize the value of popular music by comparisons to concert music. So, jazz was, in the mid-1950s, characterized as music to be listened. In the late 1960s the articles in Terä often stated that the sound and melody structures of rock music reminded of concert music. In that respect the esteem of the high culture was still present in the assessments of popular music.

\section{Notes}

1 On the history of the movement, e.g. Tauno Saarela, 'Finnish Communism, Bolshevization and Stalinization', in Bolshevism, Stalinism and the Comintern. Perspectives on Stalinization, 1917-53. Edited by Norman LaPorte, Kevin Morgan and Matthew Worley. Palgrave Macmillan: Basingstoke, New York 2008, 188-205.

2 Kulttuuri koko kansan omaisuudeksi. SKDL:n kulttuuriohjelma. Helsinki $1947,1$.

3 On this, e.g. Tauno Saarela, Suomalainen kommunismi ja vallankumous 1923-1930. SKS: Helsinki 2008, 676-677, 711-715.

4 Kulttuuri koko kansan omaisuudeksi, 9.

5 Vesa Kurkela, Tanhuten valistukseen. Musiikkivalistus ja perinnetyö Suomen demokraattisessa Nuorisoliitossa. Työväenmusiikki-insituutti: Helsinki 1986, 112-114.

6 Drummer Boy, 'Swingin tahdissa', Terä 26 May 1945.

7 'I'm getting sentimental over you', Terä 2 June 1945; Dix, 'Jazzin kehityksen pääpiirteet', Terä 9 June 1945; Dix, 'Louis Armstrong - King of the Trumpet', 
Terä 16 June 1945; Dix, 'Jazzorkesterin kehitys', Terä 7 July 1945; 'Jazzin terminologiaa, Terä 30 June, 7 July and 15 September 1945.

8 Paulus Rumbling, '”Eläköön swing!', Terä 14 July 1945; 'Swing? Marakatin vikinää ..., Terä 9 August 1946.

9 E. S-nen, 'Eräs "kulttuurikriisi", Terä 28 July 1945; Dix, "'Swing, kaiken pahan juuri', Terä 4 August 1945; 'Swing? Marakatin vikinää ..., Terä 9 August 1946.

10 See, e.g. S. Frederick Starr, Red and Hot. The Fate of Jazz in the Soviet Union 1917-1980. Oxford University Press: Oxford and New York 1983, 207-223; Timothy W. Ryback, Rock around the Bloc. A History of Rock Music in Eastern Europe and the Soviet Union. Oxfrod University Press: Oxford, New York 1990, 11-12.

11 Kurkela, Tanhuten valistukseen, 125-129; on the articles, Pee, 'Terpsikhoren palvelijain pakeilla', Terä 5 March 1948; Kazimierz Dobrynski, 'Jazzi ja Beethoven', Terä 17 December 1948.

12 Kurkela, Tanhuten valistukseen, 138-150.

13 Olli Laine, 'Jazz - tuomittava vai hyväksyttävä, Terä 9, 10, 11 and 12/1955.

14 Narrator, 'Mitä on jazz?', Terä 3/1957; Narrator, 'Jazzia puolen vuoden takaa', Terä 4/1957; Narrator, 'Swingistä nykyjazziin', Terä 5/1957.

15 Narrator, 'Kylmän jazzin aikakaudella', Terä 6/1957.

16 'Jazzin maailmasta', Terä 9/1957.

17 'Bachista be-bopiin', Terä 9/1958 praised Getz meets Mulligan.

18 Narrator, 'Heroini tappaa kuninkaita', Terä 9/1957.

19 "Nuori rakentaja”, "'Terä, palaa tieltäsi!", Terä 5/1957; "Nuori rakentaja”, 'Mitä onkaan kulttuuri?', Terä 9/1957; 'Uvertyyri', Terä 1/1958.

20 “Nuori rakentaja”, 'Mitä onkaan kulttuuri?', Terä 9/1957.

21 'Bachista be-bopiin', Terä 1-12/1958.

22 Kurkela, Tanhuten valistukseen, 166, 171-172; Esko Jämsén, 'Jazz-konsertti', Terä 3/1965.

23 See, e.g. Jazz-Jonne, 'Aikamme huippujazzia', Terä 6/1962

24 See, e.g. Sakari Warsell, Georg Malmstén. Suomen iskelmäkuningas. WSOY: Helsinki 2002; Pekka Jalkanen-Vesa Kurkela, Populaarimusiikki. Suomen musiikin historia. WSOY: Helsinki 2003, 299-306.

25 Maallikko, 'Ikuisesti nuori', Terä 26 March 1953; 'Nostan hattuani', Terä 1953; 'Suomalainen iskelmä gulassiajan kabinettikulttuuriako?', Terä 6 May 1953.

26 Kurkela, Tanhuten valistukseen, 142.

27 See e.g. Helena, 'Tanssiko vain kiinnostaa', Terä 2/1955; 'Boogie-woogie', Terä 4/1955; Yksi monista tanssijoista, Tartutaanpa tanssikulttuuriin, Terä 6/1955; Helena, 'Jivestäkö valssin hauta', Terä 8/1955; Hidas valssi tanssin kuningatar, Terä 8/1956.

28 'Nuoruuden esiinmarssi iskelmien tahdissa', Terä 2/1957.

29 See, e.g., 'Kuume, joka ei mene ohi ..., Terä 2/1956; '”Rakkain yleisöni on nuoriso ...", Terä 9/1956; 'Calypso ja sen laulaja - Harry Belafonte', Terä 12/1957; '”Tenorino Calmerino', Terä 6-7/1959; 'Harri Vasar', Terä 11/1959. 
30 See, e.g. Olli Laine, 'Lasse Liemola laulaa enää vuoden', Terä 1/1961; Kullervo, 'Kai Lind ihailee Frank Sinatraa, Terä 4/1961; Minor, 'Kai Pahlmania tapaamassa', Terä 4/1962; Aarre Nojonen, 'Tamara kotiutui Moskovaan', Terä 6/1964; Esko Jämsén, 'Ja lauloi kans niin helvetin hyvin', Terä 11/1965.

31 Erkki Rahkola, 'Iskelmissäkö olisi toivomisen varaa?', Terä 5/1959.

32 Martti Savo, 'Tunnista tuntiin!', Terä 11/1956; Katarina Beylin, 'Rock and Roll ja Beethoven, Terä 8/1957; see also Brevis, Rytmiriihi, Kansan Tahto, 11 February 1961 and 17 January 1962.

33 'Terän tanssituokio, Terä 1-12/1961, 1-12/1962 and 1-12/1963; Pa-Sa,'Tanssimme tuokion', Terä 1-12/1964; Pa-Sa, 'Iskelmämylly', Terä 1-12/1965.

34 See e.g., Kurkela, Populaarimusiikki, 473-482.

35 On the concerts at Kulttuuritalo, see e.g., Aleksi Malmberg, Musiikki, politiikka ja paikan henki. Helsingin Kulttuuritalon konserttitoiminta vuosina 1957-1972. Master thesis in Musicology, University of Helsinki. September 2006, 52-55, 76.

$36 \mathrm{~Pa}-\mathrm{Sa}$, Tanssimme tuokion, Terä 1/1965.

37 See e.g., Pop + epäpop, Terä 1/1966; psis, kaunoiskelmät kukoistavat, Terä 5/1966.

38 Pirkko Molander, folk-fredi, folk-haastattelu, Terä 2/1966; Lauri Luotonen, mr. hector, pasifistimme, Terä 8/1966; ps+is, anki verkossa eli 42 tapaa turmella mona lisan hymy, Terä 9/1966; Lauri Luotonen, Suomen Päivi Paunu, Terä 11/1966, ahti susiluoto, muksujen lipponen, Terä 15/1966; mattijuhani koponen, rotesti-simo sanoo simasta, spedestä ja itsestään, Terä 17/1966.

39 'Pasifismia, protesteja', Merkkituli Terä 4/1965; Pirkko Molander, 'Phillips Donovan', Terä 12/1965; ilpo saunio, 'folk-kansa Sandvikissa', Terä 10/1966;'One man's hands - kädet', Terä 11/1966; ilpo saunio, 'donovan hoppel poppel', Terä 2/1967.

40 Jyrki Parkkinen, 'Aja hiljaa baby', Terä 11/1966.

41 Muddy Waters' Got my mojo working was, however, presented, see, ilpo saunio, 'donovan hoppel poppel', Terä 2/1967.

42 Ilpo Saunio, 'Tappajakansaa - kesän eräät ruusut', Terä 13/1967.

43 Ilpo Saunio, 'Päivää blues - kirvesvarttako?', Terä 19/1967.

44 Ilpo Saunio, 'Hymnejä latomakoneelle ja kahdelle taittajalle', Terä 11/1967.

45 Risto-Juhani Suokas, 'Pop-musiikin mahdollisuuksia', Terä 7-8/1967.

46 Ilpo Saunio, 'Yksinäisten sydänten klubi', Terä 12/1967.

47 ibid.

48 Ilpo Saunio, 'Populaarimusiikki on hätkähdyttävää, Terä 2/1968.

49 Ilpo Saunio, 'Ruvettiin valistumaan', Terä 22/1967.

50 Kalev Tiits, Erkki Kurenniemi - Avantgarden innovaattori, Musiikkitiede 2/1990.

51 Ilpo Saunio, 'Ruvettiin valistumaan', Terä 22/1967.

52 Ilpo Saunio, 'Populaarimusiikki on hätkähdyttävää, Terä 2/1968.

53 Ilpo Saunio, 'Yksinäisten sydänten klubi', Terä 12/1967; Ilpo Saunio, 'Populaarimusiikki on hätkähdyttävää, Terä 2/1968. 
54 Ilpo Saunio, 'Kirkonkylän kioski - pop-musiikin Waterlooko?', Terä 12/1967; Ilpo Saunio, 'Organisoitua hälyä nousevassa ja laskevassa potenssissa', Terä 18/1967.

55 'Mitä Suomi soittaa', Terä 7/1966, 10/1966, 15/1966, 18/1966, 1/1967, 18/1967; 'Beatlesit ahdistavat Elsaa', Terä 7-8/1967; 'Elsa-humalasta kauhea kankkunen', Terä 10/1967; 'Elsa ja Sgt. Pepper kärjessä, Terä 13/1967.

56 Matti Lahtinen, 'Tampereen yhdeksän ylintä, Terä 17/1966; 'Johnny kärjessä Oulun levyraadissa', Terä 3/1967; 'Pirtin kahdeksan kärjessä, Terä 3/1967; 'Young time Oulu', Terä 7-8/1967; 'Pirtin kahdeksan kärjessä, Terä 10/1967; Petteri, 'Ryysyranta kiilasi listan kärkeen Pirtissä, Terä 18/1967.

57 Reijo Viitanen, Punainen aate sininen vaate. Suomen Demokraattinen Nuorisoliitto 50 vuotta. SDNL: Helsinki 1994, 464-466, 508-514.

58 'Tittelit pois. Tuure Lehen valokeilassa', Merkkituli Terä 4/1965.

59 Literally journeymen's song.

60 Viitanen, Punainen aate, 148-150.

61 Saarela, Suomalainen kommunismi ja vallankumous, 722-730.

62 Vesa Kurkela, 'Kisällien laulut - agitaatiota ja viihdettä', in Etnomusikologian vuosikirja 1987-1988. Suomen etnomusikologinen seura: Helsinki 1988, 94-95.

63 Pekka Gronow, 'Kisällilaulu', in Paimensoittimista kisällilauluun. Tutkielmia kansanmusiikista. Toimittaneet Heikki Laitinen, Simo Westerholm. Kansanmusiikki-instituutti: Kaustinen 1976, 223, 226-228, 234; Vesa Kurkela, Taistojen tiellä soiteltiin - ja soiton tahdissa tanssittiin. Varkautelaiset työväeniltamat ja niiden musiikki työväen osakulttuurin kaudella. Työväenmusiikki-instituutti: Helsinki 1983, 251-255.

64 Aili Mäkinen, Mitä laulamme, miten laulamme, Terä 1/1951.

65 Kurkela, Taistojen tiellä soiteltiin, 254-255; Marko Pulkkinen, ”Laulakaamme natsiveikoin esiinmarssista ...". Suomen demokraattisen nuorisoliiton kisällilaulut nuorisoliiton ja kansandemokraattien politiikan representaationa. Master Thesis of Political Science, University of Jyväskylä 1994, 56-63, 70-80.

66 Kurkela, Tanhuten valistukseen, 136.

67 Ilpo Saunio, Veli, sisko, kuulet kummat soitot, Työväenlaulut eilen ja tänään. Kansankulttuuri: Helsinki 1974, 296; Kurkela, 'Kisällien laulut', 115-116.

68 Marja-Leena Mikkola, 'Kulttuuriradikalismi - porvariston luokaton lakeija, Terä $1 / 1969$.

69 See. e.g., Pulkkinen, "Laulakaamme natsiveikoin esiinmarssista", 103. 



\section{Leader cults}





\section{Dead martyrs and living leaders The cult of the individual within Finnish communism}

The communist movement was supposed to overthrow the existing capitalist system and its hierarchies. In order to promote this goal, however, it adopted the habit of venerating its influential leaders. This was partly due to the strong Russian influence on the international communist movement. A Lenin cult was in the making from 1918 onwards, and got wind in its sails after Lenin's death in January 1924. In the 1930s the celebration of Lenin was little by little sidelined by the emerging Stalin cult. ${ }^{1}$ The celebration of Stalin assumed vast proportions, especially in 1949 when the whole of the Soviet Union and the entire international communist movement commemorated his seventieth birthday. ${ }^{2}$ The leader cult was also adopted in the people's democracies in the late 1940 s and early 1950 s. $^{3}$ In countries where communists were in power, the leader cult legitimised the power of the small ruling group but also managed relations between the governing stratum and the wider society. ${ }^{4}$

In the communist parties which were not in power, the habit of celebrating certain persons was also adopted. However, the creation of a leader cult, which again was more pronounced in the late 1940s and early 1950s, could not promote the same goals in these parties. ${ }^{5}$ In this article I study how these model individuals were chosen in Finnish communism from the 1920s to the 1960s. I try to establish on what grounds and for what reasons a person became a celebrated model; what kinds of issues the creation of 
model persons was connected to; and how national traditions and circumstances influenced the celebration of these individuals.

No claims of typicality are made. Finnish communism, indeed, was not a typical communist movement, but was born in two countries, in Soviet Russia and in Finland. ${ }^{6}$ The birth of the movement was also closely connected with the abortive revolution and civil war in Finland in 1918. The Red revolutionary leaders escaped to Soviet Russia in the spring of 1918 and founded the Finnish Communist Party (SKP) in Moscow in August 1918. Proscribed in Finland and forced to work underground, the SKP had its principal organs in the Soviet Union until 1944. Meanwhile, the movement that had been born in Finland in 1919 had been a reaction to the fact that the new leaders of the Social Democratic Party (SDP) had condemned the revolution and taken their distance from the principles of the pre-civil war party. This was regarded by many party members as an accommodation to the views of the victors of the civil war. In December 1919 these critics and the SKP representatives met in an attempt to win over the SDP party congress. In May 1920, having failed to gain a majority, they founded the Socialist Workers' Party of Finland (SSTP).

The movement to the left of the social democrats met with difficulties from the very beginning. Then in August 1923 the activities of the SSTP were forbidden, and its national and local leaders and members of parliament arrested and sentenced to prison. Although the movement was then organised into looser electoral, cultural and other associations, even these were proscribed in the summer of 1930 . Henceforth, and until the autumn of 1944, Finnish communism, apart from the SKP leadership in Moscow and its underground functionaries in Finland, consisted of individuals or small groups trying to work inside political and labour movement organisations. In these circumstances, the new ideas and methods of the international communist movement were mixed with the traditions of the Finnish labour movement and adapted to the pressures of the situation within Finland. The circumstances did not, however, inspire the veneration of any liv- 
ing national personality or revive the celebration of established national heroes.

Members of the early labour movement had taken part in memorial days organised in honour of Johan Ludvig Runeberg, the national poet, and Johan Vilhelm Snellman, the nineteenth century statesman. The practice of celebrating the labour movement's own great men had also come into existence at the time of the fifty-fifth and sixtieth birthdays, in 1909 and 1914 respectively, of Nils Robert af Ursin. Ursin was a nobleman who had held the leading positions in the Finnish labour movement from the 1880 s to 1905 , and during these celebrations his standing as 'the grand old man of the labour movement' was backed up by reports of the international honours he had received from Germany and Sweden. ${ }^{7}$ In the 1920s, however, these Finnish-based celebrations were replaced by the anniversaries developed within the international communist movement, especially those commemorating Karl Liebknecht, Rosa Luxemburg and V.I. Lenin. ${ }^{8}$

Figures in the Finnish movement, however, were not entirely forgotten. As the leadership in Finland was often changed by imprisonment, it was difficult to promote any particular leader cult. Instead, the abolition of political imprisonment was a key campaigning issue, and by presenting the experiences of political prisoners the movement was able to reproach the existing system for brutality and indifference, while presenting the victims as model communists. As so many had died in the civil war, or were subsequently imprisoned, no individual was raised above the others, and it was more usual to honour their collective example. ${ }^{9}$ But even in the 1920 s, some individuals were accorded a special prominence.

\section{Prisoners and martyrs}

The first instance took place in September 1923 when Yrjö Mäkelin died in the prison. Mäkelin was a famous newspaperman and former member of parliament who had taken the side of Fin- 
nish communism while emphasising the personal character of his communism. His death, however, was caused by an overdose of sleeping pills and was not very easy to use as an example of heroism or as an indictment of the existing system..$^{10}$ In the Bolshevik tradition suicide could be an honourable way of presenting moral protest or handling a difficult situation. ${ }^{11}$ In the Finnish labour movement, on the other hand, that kind of an interpretation was not familiar, and the leaders of the SKP more particularly did not include suicide in their modes of action. It could be suggested that Mäkelin's action might be a sign of strength. ${ }^{12}$ It was more usual, however, to argue that the Central Detective Police had poisoned him. ${ }^{13}$ Subsequently his death was not touched upon in detail, and newspapers stated that he died in peculiar circumstances. ${ }^{14}$ It was, however, more common to point out that Mäkelin died in the struggle - 'dressed in war attire and falling like a hero.' ${ }^{15}$

Mäkelin became a symbol because he died when Finnish communism was encountering difficulties in expressing its voice. His commemoration was also influenced by social-democratic innuendos that he committed suicide having realised his support of communism as a mistake. In a difficult situation, not even the SKP leaders wanted to hand the Mäkelin heritage over to social democrats, despite their differences with him in the 1910s and again in 1922. Yrjö Sirola, a member of the SKP leadership, pointed out that practical activity had been more important for Mäkelin than theoretical assessments, and that Mäkelin had been prevented by his conscience from joining the 'Noskeans'.

Mäkelin's commemoration would have been limited to a set of postcards about his funeral had the trade union movement in the north of Finland not decided in February 1925 to mark the anniversary of his death in order to collect money for the statue on his grave. Anniversary meetings were supposed to have taken place around the country, but were concentrated in the neighbourhood of Oulu, where Mäkelin had lived since 1907. His commemoration there was actually more popular than the anniversaries of Liebknecht, Luxemburg and Lenin that were becoming part of 
the yearly calendar of the Finnish communist movement. Nobody, however, attempted to point to the resemblances between the deaths of Liebknecht, Luxemburg and Mäkelin. ${ }^{16}$ Usually it was argued that political opponents had imprisoned Mäkelin to stop him from writing. The main focus was thus on the ruthless disregard for democracy of those in power. By pointing to Mäkelin's example, the articles were also meant to urge workers into action for their civil rights and liberties. These activities were not to be hindered by the threat of imprisonment as their 'natural' consequence. Consequently, dedication to the cause was rather strongly connected with imprisonment, which would always be the lot of heroes.

As one of the best-known journalists of the labour movement, Mäkelin's trademark had been his lively informal pieces, which were complaisant rather than confrontational. Nevertheless, it was a more aggressive, jeering approach that was emphasised in the posthumous celebration of his penmanship. 'His pen had a sharp tip, it was a lance which did not spare the enemy', ran one.

When it struck, it could contain frightening anger, but he did not direct angry blows at everyone. Where his enemies hardly deserved his anger, he directed waspish remarks and jokes at them. ${ }^{17}$

The unveiling of the statue on Mäkelin's grave took place in September 1928. As many as four thousand people gathered there to pay their respects and also bid Mäkelin farewell - for the completion of the statue marked the end of his commemoration. ${ }^{18}$

Finnish communism, or at least its Helsinki section, acquired a new martyr in 1929. At the time of his arrest in April 1928, Väinö Vuorio, central figure of communism in Finland in the 1920s, was already suffering from tuberculosis. ${ }^{19}$ In prison the disease became worse, and despite Vuorio's belated removal to a sanatorium he died at the age of thirty-three at the end of June 1929. His funeral procession was turned into a demonstration in which over five thousand people participated. The youth of Finnish communism in particular wanted to carry on his commemoration by organising meetings on his work in the labour movement. There 
were also plans to publish a book about him and a collection of his articles. Vuorio was posthumously characterised as 'an ardent youth unionist', which may have been a euphemism in view of the risk involved in referring to his leading position in the communist movement. But though he may have been depicted as ardent, Vuorio's merits were rather those of a political realist who did not take to defiance but sought to safeguard the possibilities of the movement's activities in difficult conditions. After the more comprehensive suppression of such activities in the summer of 1930, Vuorio's commemoration did not get beyond in its early stages, and only a set of postcards was published.

This example, with that of Mäkelin, shows that in the 1920s the communist movement concentrated on exposing the brutality of the Finnish establishment through the prison deaths of its members. Similar incidents occurred in other countries, for example in the Baltic states and Poland, but these were only occasionally presented in the papers of the Finnish movement. A far greater solidarity was expressed in the campaigns against the death sentences of the Italian-American anarchists Sacco and Vanzetti. Their execution in 1927 revived the memory of the vindictive death sentences that had been imposed in Finland in the spring of 1918, and this helps explain the strong sense of solidarity aroused. ${ }^{20}$ Besides demonstrations, this was expressed in the announcement by the Finnish trade union movement of a boycott of products made in the USA. ${ }^{21}$

\section{'Dimitrov of the Nordic countries'}

Other Finnish communists died in prison in the early 1930s, but their commemoration as model communists was restricted to underground papers and the opportunity provided by their funerals. ${ }^{22}$ Attempts to create communist exemplars were nevertheless carried on in other ways. The arrest in November 1934 of Toivo Antikainen was the most important of them. Antikainen was a member of the SKP politbureau and was at that time guiding the 
underground work of the party in Finland. Leading figures in the SKP had previously been arrested in the early 1920s and, as we have seen, in 1928. However, the case of Antikainen aroused greater publicity because of the demand by Finnish right-wingers that he be convicted of a murder he had allegedly committed in Karelia in 1922, and their call at the same time for the restoration of the death penalty. A committee opposing the death penalty was founded on the initiative of liberal-minded intellectuals. Some social democrats also participated on grounds of moral opposition to the death penalty, and 120,000 signatures were collected against its restoration. The communist movement concentrated more directly on defending Antikainen in court and securing him legal assistance. ${ }^{23}$ Many communist parties, using information circulated by the Comintern or International Red Aid, published short pamphlets or articles on the trial. ${ }^{24}$ These publications focused on the biased character of the Finnish legal system and the attempt to prevent Antikainen from defending himself, in contravention of international principles of justice. Parallels were drawn between the Antikainen case and the Leipzig trial of Georgi Dimitrov in 1933. The Swedish Red Aid went so far as to call Antikainen the Dimitrov of the Nordic countries. ${ }^{25}$ In the Communist International he was compared with Dimitrov and Ernst Thälmann, the German communist leader imprisoned by the Nazis.

These themes were in harmony with the emerging accents of the popular front. The descriptions of Antikainen's life history, on the other hand, were more ambiguous; for, while repudiating the accusations of murder and affirming Antikainen's decency, they also depicted the communist cadre in a way which was new in Finland. The presentation was not only more detailed than those of Mäkelin and Vuorio, but it was peppered with various superlatives in its descriptions of Antikainen. In many respects Antikainen was a suitable person as a communist model. He was born in 1898 into a working-class family with several children, and was described as contributing to the family income from the age of seven by selling newspapers before he went to school. His oc- 
cupation as an upholsterer received less attention, however, and was overshadowed by his precocious connections with the labour movement and his rise to leading posts in the social democratic youth union at the age of nineteen. ${ }^{26}$ From the communist point of view, his merits were increased in 1918 when he participated 'with flaming enthusiasm' in the revolutionary fights in Finland. Even more praiseworthy was the fact that, having escaped to Soviet Russia after the abortive revolution in Finland, he had joined the Red Army and, as 'a skilled red commander', had participated in the fights against Yudenich, various interventionists and the 'Kronstadt counterrevolutionaries.'. ${ }^{27}$ Although Antikainen was one of the founders of the SKP and became a leading political functionary at the end of 1923, this image of the 'red commander' was a pronounced theme in these presentations. Of course it was necessary to demonstrate Antikainen's decency as a soldier. But the importance of his military schooling may also have reflected the thinking of the 'third period', and expectations of armed revolution in the near future.

Descriptions of Antikainen's career in the SKP leadership also sang his praises: as 'a vigorous and unrelenting organiser', whose articles and speeches presented the party's tasks 'clearly and sharply', and whose 'sharp political intelligence, theoretical clarity and revolutionary energy and activism' made him a party leader. He was not, however, the greatest leader of Finnish communism, as was indicated by the formulation 'the closest and best co-worker of comrade Kuusinen.'. ${ }^{28}$ Imitating contemporary Soviet descriptions of Lenin and Stalin, the reference to Kuusinen was to Otto Ville Kuusinen, Moscow-based secretary of the Comintern, who had a central position in the SKP leadership, although he was never officially its chairman. ${ }^{29}$

Despite these glowing characterisations, the overall view of Antikainen was more defensive than that of comparable figures in the German and British communist movements. Despite his military activities, Antikainen was not presented with the same level of assertion as the German party leader Thälmann in the presidential elections in 1925 or within the paramilitary Roter 
Frontkämpferbund. Nor - due to his position as an accused person and the underground character of the SKP - was he portrayed as a leader protecting the movement against the outside world or challenging its enemies. ${ }^{30}$ And after he received a life sentence in 1935, publicity around him diminished. He was not forgotten, however, and in May 1940 he returned to the USSR in an exchange of prisoners, and resumed his place in the SKP leadership - which had been nearly destroyed in the purges. He died a mysterious death in October 1941, when the plane carrying him from Archangel to Moscow crashed soon after takeoff. ${ }^{31}$

\section{'The eminent theoretician' and 'the iron helmsman'}

With the SKP's emergence from the underground, the People's Democratic League of Finland (SKDL) was formed in the autumn of 1944 as a new organisation to the left of the SPD, embracing communists, socialists and left social democrats. Attempts were made to remember Antikainen as 'a model revolutionary' and 'an acknowledged leader of the party. ${ }^{32}$ Nevertheless, he could not provide the model of a living communist leader, and, with the movement's participation in the government between 1945 and 1948, it was perhaps the Minister of the Interior, Yrjö Leino, who provided such a mode $1 .{ }^{33}$ It was only after the movement's exclusion from the government in mid-1948 that the SKP began to foster a more definite leader cult around Otto Ville Kuusinen.

Kuusinen's career had started in the Finnish labour movement in 1905, but after the civil war he had mainly lived in the USSR, serving in the Comintern secretariat from 1921 to 1943 and as leader of the Karelian-Finnish Soviet Socialist Republic from 1940 onwards. Though he was a respected counsellor to the SKP after 1944, he was nevertheless obliged to remain in the Soviet Union. ${ }^{34}$ The cult around him differed profoundly from earlier examples in not being attached to any particular event or action with which he was identified, but with the celebration of his birthday. ${ }^{35}$ 
The anniversaries of living leaders had not previously received a great deal of attention within the Finnish communist movement. Kuusinen's sixty-fifth birthday in October 1946, however, indicated a change, as the SKP organ Työkansan Sanomat devoted several articles to him. Five years later the attention given to his birthday was much more considerable. A large portrait photograph and the greetings of the party committee covered the whole front page of the paper, which was largely devoted to Kuusinen. Local communist papers offered lesser, but still extensive coverage, while the SKDL organ, Vapaa Sana, gave over three of its eight pages. Speeches and articles of Kuusinen's from 1918 to 1949 were published in a book, Kansainvälisiä kysymyksiä (International issues), which was intended to convey important lessons for Finland. The whole of the party organisation was harnessed to the campaign through the organisation of celebratory meetings, such as the one in Helsinki's Messuhalli (Fair exhibition hall), where the backdrop to the platform showed Lenin's and Stalin's reliefs connected by a red line to a photograph of Kuusinen. The text ran Long live Kuusinen - student of Marx, Engels, Lenin and Stalin - the greatest Finnish flag-bearer of communism! Featured in the proceedings were the speech of party chairman Aimo Aaltonen, further greetings to the absent leader, and a festive poem Pohjolan punainen honka (The red old pine of the North). Similar events were held elsewhere, but were not as bombastic. One special reception offered an opportunity to organisations and members to deliver gifts and congratulations, which the SKP leadership received on Kuusinen's behalf. ${ }^{36}$ These included flags, handicrafts, a metallic globe, a peace dove, a kantele, the traditional Finnish music instrument, and a rug picturing Kullervo from the Finnish national epic the Kalevala. ${ }^{37}$ In Jyväskylä, where Kuusinen had been to school, communists proposed to the city council that the street leading towards Kuusinen's home village should he renamed Otto Ville Kuusinen street. ${ }^{38}$

Such celebrations were not without paralleled in other countries - Harry Pollitt in Britain was one example ${ }^{39}$ - but had no precedent in the history of Finnish communism. This was also 
true of the characterisations of Kuusinen presented at meetings and in newspapers. In the official vocabulary of the SKP in 1951 Kuusinen was characterised as the 'student' or the 'greatest Finnish champion' of Marx, Engels, Lenin and Stalin, or as 'the greatest Finnish flag-bearer for the victorious ideas of Lenin and Stalin'. Articles about him showed little variation; they stressed his thorough knowledge of the ideas of Lenin and Stalin', and his standing as 'one of the most prominent theoreticians in the international communist movement. ${ }^{40}$ Attempts to depict him as a politician and man of action were less conspicuous. This was partly because of communists' respect for the priority of theory, but was also due to the difficulty of finding other ways to indicate how Kuusinen's prominence had manifested itself. His activities were usually written about in rather general terms. Sometimes his merits were discovered in the fight against war and fascism and in the defence of democracy. ${ }^{41}$ More commonly, examples were presented relating to his earlier role in the Finnish labour movement, and he was even depicted as the leading actor in the People's Deputation of 1918. ${ }^{42}$ Kuusinen was also described as one of the founders of the SKP. Indeed, it was claimed that the party was founded on his initiative. The party was also supposed to have been working under his guidance in the 1920s and 1930s, or at least to have received his assistance on various occasions. ${ }^{43}$ Particularly in relation to the social democrats, it was stressed that he had taught how the working class could fulfil its historical task only by expelling the betrayers of the class struggle. ${ }^{44}$ In Kommunisti, the SKP's theoretical organ, the fight for the leninist line against opportunist deviations was also considered an important part of Kuusinen's legacy. ${ }^{45}$ There was a tendency to study even his pre-communist activities through communist glasses, notably in discussion of the draft of the constitution he had written in 1918. This was equated with the dictatorship of the proletariat, although in reality, in its emphasis on the significance of parliament and referendum, it had been much more in harmony with the ideas of western marxism. ${ }^{46}$ 
Short biographical articles reinforced the impression that Kuusinen was the only leader of the SKP. This idea was strengthened by the fact that Kullervo Manner, the leader of the People's Deputation in 1918 and SKP chairman from 1920 to 1934, had been removed as a deviationist and remained largely unmentioned. ${ }^{47}$ Kuusinen was the SKP's 'iron helmsman', and Kommunisti gave the impression that he had been the first in every action, and that everything had been done under his leadership or on his initiative. For those who had known Kuusinen as a Comintern functionary and a leader of the SKP, it was natural to emphasise his contribution in this regard. But their characterisations were also strongly influenced by their having lived in the USSR, and adapted to the cultic practices and style of communist history writing initiated by Stalin in the early 1930s. Their characterisations of Kuusinen were meant to instil in the party members respect and obedience towards the SKP leadership, and a sense of the importance of a united and resolute communist party. In stressing Kuusinen's theoretical and political eminence, they were also meant to demonstrate the significance of marxism-leninism as a scientific world view.

\section{International patriot}

In the divided world of the late 1940s, peace too became an important characteristic of the communist leader cult. Stalin himself was called 'a warden of peace', who would prevent the outbreak of a new war. ${ }^{48}$ Kuusinen's merits as the builder of peace between Finland and Stalin's USSR were also recognised throughout the Finnish communist movement. A patriot and fighter for the brotherhood of nations, he had fought for Finland's independence from the beginning of the century, while understanding the importance of safeguarding the friendship between the peoples of Finland and the USSR ${ }^{49}$ Finnish communists claimed that the Winter War of 1939-40 need never have occurred had Kuusinen's ideas for the peaceful resolution of differences been accepted. ${ }^{50}$ 
Even Raoul Palmgren, who had gone to the front to defend Finland, regarded Kuusinen's participation in the Terijoki government as an attempt to prevent the war from becoming a national disaster. ${ }^{51}$ For the Finnish bourgeoisie, however, Kuusinen symbolised the Soviet origin and interests of Finnish communism, as indicated by the establishment of the Terijoki government in November 1939, or his participation in anti-Finnish propaganda during the Continuation War of 1941-4. Kuusinen's characterisation as a 'peace fighter' implied criticism of this nationalist perspective, and the advocacy of a new kind of perspective based on internationalism and the principles of marxist-leninism. ${ }^{52}$

The depiction of Kuusinen's eminence in the fields of theory and politics and his connections to the leaders of the international labour movement suggested a new conception of great individuals and their role in history. Mauri Ryömä, the chief editor of Työkansan Sanomat, sought as early as 1946 to teach that these individuals were able to perceive the historical and social forces of development and interpret the needs of the masses. Kuusinen filled these requirements in taking account of the needs of the Finnish people while also providing an exemplary figure for other peoples. ${ }^{53}$ Ryömä, therefore, wanted to position Kuusinen alongside other national great men such as J. V. Snellman, the nineteenth-century philosopher and statesman in Finland. By 1951, his merits were being compared instead with those of Carl Gustaf Mannerheim, the Marshal of Finland, whose seventieth and seventy-fifth birthdays in 1937 and 1942 respectively, and funeral in 1951, had been national events. However Mannerheim - who before the October revolution had been in the service of the Imperial Chevalier Guard and Imperial Russian Army - was not mentioned when communists wished to emphasise Kuusinen's unrivalled international standing, as confirmed by the international messages he received in 1951, and by Soviet awards such as the Order of Lenin, also granted in $1951 .{ }^{54}$ Though the aim was to show that the Finnish working class had produced leaders as significant as those of the Finnish bourgeoisie, it was Stalin's seventieth birthday that provided the model for Kuusinen's 
commemoration. Of course, communists in Finland were not in a position to mobilize the whole people in the celebration, as they were in the Soviet Union or the people's democracies.

\section{Kuusinen and the disclosures of 1956}

For Kuusinen's seventy-fifth birthday in October 1956 there were no festive meetings, and newspapers were not filled with his photographs, or articles describing his feats. Explaining the change, Ryömä stressed that it was not in accordance with the labour movement's principles to worship its distinguished leaders, to overestimate their contribution, or to underestimate or despise ordinary people. Ascribing this kind of attitude to the bourgeoisie, Ryömä admitted that even the labour movement occasionally fell into this trap, though at the same time he reaffirmed the importance of prominent individuals, who should he honoured where they expressed the will of the people and loyally served its cause. Since Kuusinen remained such a person, Ryömä continued his article by describing his career. ${ }^{55}$ No mention was made of Khrushchev's disclosures regarding Stalin and the personality cult at the CPSU's Twentieth Party Congress in February of the same year. Nor did Ryömä recall Kuusinen's own vast celebration in 1951. Nevertheless, the article showed how Finnish communists had quickly adapted to the Khrushchev revelations. Five years later, when Kuusinen celebrated his eightieth birthday, the SKP seemed to have found a balance. The party and the SKDL parliamentary group organised modest meetings, newspapers published some articles, and the SKP published a book, Suuri vuosisata, containing Kuusinen's memoirs of his underground activities in Finland in 1919 to 1920, and his speech on Lenin in $1960 .^{56}$

The changes that took place were not only evident in the volume of celebration of Kuusinen's birthdays. References to Kuusinen as a student of Stalin were replaced by a more general reference to communist doctrine. In 1961 Kuusinen was hailed as 'the 
most prominent Finnish representative of the great marxist-leninist ideas', or was more modestly placed 'in the vanguard of the Marxist theoreticians produced by the Finnish labour movement'. It was also usual to stress Kuusinen's creativity in the field of marxist-leninist theories. ${ }^{57}$ The change was due to the revelations about the Stalin cult by Khrushchev, but also to the fact that Kuusinen had established a name for himself in the field of theory after The Fundamentals of Marxism-Leninism, written under his leadership, had come out in $1959 .{ }^{58}$

This contributed further to Kuusinen's activities as a politician remaining ever more in the shadow of his role as a theoretician. There were, however, references to Kuusinen's influence on the decisions of the SKP. The assessments of Kuusinen's international patriotism were also repeated on some occasions, but there was a growing tendency not to mention the Terijoki government as one of Kuusinen's great achievements. ${ }^{59}$

Although Finnish communists campaigned extensively for Kuusinen, they were not able to have any great impact on the dominant ideas concerning him. Thus a street dedicated to Kuusinen did not come into being in Jyväskylä; the other political groups were against naming a street after a living person. ${ }^{60}$ That was partly an excuse, for a street was named after Mannerheim in Helsinki during his seventy-fifth birthday in 1942, and a park was named for Sibelius on the occasion of his eightieth birthday in $1945 .{ }^{61}$ The objection was political, and this was made evident in the response of people in Kotka to the attempts to declare Kuusinen the greatest Finnish patriot; strips of window paper were attached to posters advertising Kuusinen's birthday in 1951 that read 'the destroyer of Tiutinen'.62 The negative attitude to Kuusinen was also evident during the fortieth anniversary of the SKP in 1958; he was not considered welcome, and because of 'his personal past', and its negative influence on the atmosphere of friendship and good will, he was not given a visa to Finland as the head of the CPSU delegation. ${ }^{63}$ 


\section{'Merited students of Kuusinen'}

Kuusinen was not able to come to Finland, but from 1951 onwards his larger-than-life-size picture was displayed at demonstrations and impotant meetings. This too was a new feature in the Finnish communist movement, who were following the examples of the Soviet Union and the people's democracies. ${ }^{64}$ Besides Kuusinen, photographs of other leaders were also displayed at such events - Antikainen; the party chairman Aimo Aaltonen; its general secretary Ville Pessi; and Hertta Kuusinen, leader of the parliamentary group. The celebration of these other leaders, however, never attained the proportions of that of Kuusinen. Thus Pessi's fiftieth birthday in March 1952 was marked by a portrait photograph on the front page of Työkansan Sanomat, together with an article depicting him as 'a merited colleague and student of Otto Ville Kuusinen' The newspaper also published a poem dedicated to the occasion. But, although local party sections and party members congratulated him, this was not organised by the party, and Pessi received the messages at home. ${ }^{65}$

Pessi had been party general secretary since 1945, but his earlier activities were not very well known. The article in Työkansan Sanomat was therefore intended to increase the 'deep respect and trust' in which he was held, by depicting him as a trusted comrade who had held 'many responsible leading posts' in the legal and illegal communist youth movement from the mid-1920s. The article also emphasised his role in building the illegal organisation of the party 'energetically and skilfully', during a time when 'the attack of the enemy was fiercest'. The only reference to the party's indifferent success in this period was implicit in a story of Pessi's encouragement of tired and depressed party comrades on assuming the leadership of the SKP work in Finland at the end of 1934, 'with real communist readiness heedless of dangers'. The article did not mention that his leadership had proved shortlived - he was imprisoned in 1935 - but did pay great attention Pessi's endurance of his years in prison. And although it sought to emphasise his commitment to the international communist 
movement, it said nothing about his studies at the International Lenin School in 1933 to $1934 .{ }^{66}$ Pessi was seen above all as an organiser who had been foremost in making the party a significant public force. Hinting at his other capacities, it was also stated that he had indefatigably given advice to the leadership and members of the party to study the lessons of Lenin and Stalin. ${ }^{37}$ In other articles his knowledge of marxist-leninist theory was described as profound, and he was presented as 'a model for Bolshevist modesty and communist strength' ${ }^{68}$ Other leading communists ranked lower in precedence than the general secretary. On the occasion of the fiftieth birthday of Hertta Kuusinen, chairperson of the parliamentary group and daughter of Otto Ville, Työkansan Sanomat featured her portrait and an article on her life, but did not adopt the exalted tone extended to Pessi. ${ }^{69}$ Aaltonen's fiftieth birthday, in December 1956 and therefore after the Khrushchev disclosures, was met even more modestly - though, again, a short article registered his remarkable knowledge of marxist-leninist theory. ${ }^{70}$ In the case of both Aaltonen and Pessi, the importance attached to the command of theory was dear, although their actual contributions in this field were non-existent. Vague formulations about their pasts were intended to make the reader overlook the question of whether those who had spent the previous decades in underground work, the USSR or in prison were suitable for the leadership of a party whose aim was to achieve a wider influence in society.

The celebration of communist leaders decreased in the late 1950s and early 1960s. After Kuusinen's death in May 1964 the commemoration of living leaders ceased to be organised by the SKP, and the movement returned to the custom of honouring dead leaders. These included Kuusinen, whose anniversaries in 1971 and 1981 were celebrated in meetings and seminars organised by the party and the Otto Ville Kuusinen Foundation, established in 1964. During the hundredth anniversary, in 1981, the intention was to produce something more concrete, and handmade glass plates with Kuusinen's face and signature were ordered for presentation to the foreign guests of the SKP congress. The plates 
were subsequently viewed as representing the cult of personality, however, and were destroyed before the congress. ${ }^{\text {II }}$

While Kuusinen still lived, the celebration of such occasions with large festive meetings and bombastic expressions had not arisen from the wrongs of Finnish society, as had the earlier celebrations around Mäkelin, Vuorio and Antikainen. Nor was it connected with the political issues of the movement. Rather, it expressed attempts to promote an inner hierarchy within the movement, and to reaffirm the validity of marxism-leninism. For the time being at least, the tradition continued in the absence of the hero.

\section{Notes}

1 Nina Tumarkin, Lenin Lives! The Lenin Cult in Soviet Russia, Cambridge, Mass. \& London: Harvard University Press 1997 edn, pp 134-268.

2 See for example Jeffrey Brooks, Thank You, Comrade Stalin! Soviet Public Culture from Revolution to Cold War. Princeton: Princeton University Press, 2000, pp 66, 219-23.

3 See for example Balázs Apor et al (eds), The Leader Cult in Communist Dictatorships. Stalin and the Eastern Bloc, Basingstoke: Palgrave Macmillan, 2004.

4 E. A. Rees, 'The leader cults: varieties, preconditions and functions' in Apor, Leader Cult, pp 21-2.

5 Norman LaPorte and Kevin Morgan, "Kings among their subjects"? Ernst Thälmann, Harry Pollitt and the Leadership Cult as Stalinization' in LaPorte et al (eds), Bolshevism, Stalinism and the Comintern. Perspectives on Stalinization, 1917-53, Basingstoke: Palgrave Macmillan, 2008, pp 124-45; Claude Pennetier and Bernard Pudal, 'Stalinism: workers' cult and cult of leaders' in Twentieth Century Communism. Issue one, Communism and the leader cult.

6 On the birth of Finnish communism see Tauno Saarela, Suomalaisen kommunismin synty 1918-1923. Helsinki: KSL, 1996, pp 26-209; Saarela, 'Finnish communism, 
bolshevization and stalinization' in LaPorte, Bolshevism, Stalinism and the Comintern, pp189-92.

7 M. Rahikainen, N. R af Ursin - aatelismies työväenliikkeessä, Helsinki: SHS, 1986, pp 270-90.

8 Tauno Saarela, 'International and national in the communist movement' in Saarela and Kimmo Rentola (eds), Communism: National and International. Helsinki: SHS, 1998, pp 35-7.

9 See Tauno Saarela, 'Class struggle in the cemetery', Socialist History 9, 1996, pp 82-9.

10 On Mäkelin see for instance M-L. Salkola, Julistaja ja poliitikko. Yrjö Mäkelinin elämä ja toiminta. Helsinki: Tammi, 1967.

11 Sheila Fitzpatrick, Everyday Stalinism. Ordinary Life in Extraordinary Times: Soviet-Russia in the 1930s. New York \& Oxford: Oxford University Press, 1999, p 174.

12 Yrjö Mäkelinin kuolema, Revontulet, 9 November 1923.

13 RGASPI 516/2/727, SKP:n kk, Uusi valkoterroriuhri; SKP:n Oulun komitea, Laittomuuden ja terrorin maassa; SKP:n Tampereen komitea, Työväki mielivallan ja terrorin alaisena; d. 743, SKP:n Helsingin komitea, Valkoisen terrorin ja mielivallan maassa; Tov. Yrjö Mäkelin myrkytetty, Vapaus, 22 September 1923.

14 Yrjö Mäkelinin kuolinpäivänä, Savon Työ, 18 September 1926.

15 Pouttu (Mauritz Rosenberg), Muistoksi sankarille, Pohjan Voima, 19 September 1925.

16 Tauno Saarela, Kansan Tahto. Pohjolan työtätekevien lehti. Jyväskylä: Yrjö Mäkelin -seura, 2006, pp 113-15.

17 Heikki Ohto, 'Yrjö Mäkelin - taistelija, Pohjan Voima, 19 September 1925; see also R. Palmgren, Joukkosydän. Vanhan työväenliikkeemme kaunokirjallisuus 1. Porvoo: WSOY 1966, pp 307-11.

18 Saarela, Kansan Tahto, p 115.

19 On Vuorio and his commemoration see Tauno Saarela, "Tulisieluinen reaalipoliitikko” - Väinö Vuorio, in Elämää arkistossa. Kansan Arkisto 60 vuotta, Toimittanut M. Jalkanen. Saarijärvi: Yhteiskunnallinen arkistosäätiö 2005, pp 113-24.

20 See for instance 'Opiskelevan työläisnuorison katselmus Tampereella' Työväenjärjestöjen Tiedonantaja (henceforth TT), 15 August 1927; 'Valtavat työläisjoukot H:gissä Saccon ja Vanzettin muistoa kunnioittamassa' TT25 August 1927; 'Pietarsaaren työväki Sacco-Vanzettin asiassa, Työn Ä̈̈ni, 29 August 1927; 'Pohjolan työkansa liikehtii marttyyrien teloituksen johdosta', Pohjan Voima, 30 August 1927.

21 'Kaikille Suomen työläisille! Ihmisyyden ja oikeuden puoltajille!', TT, 24 August 1927.

22 See, for instance, A. Hyvönen, SKP:n maanalaisuuden vuodet. Suomen työväenliikkeen historiaa 1920-1930-luvuilla, Kuopio: Kansankulttuuri, 1971, p 236; J. Peltola, Työmailla, kabineteissa ja kaduilla. Valta ja lamapolitiikka Tampereella 
1928-1938. 1930-luvun lama teollisuuskaupungissa III Tampere: Tampere University Press, 2008, pp 204-5.

23 On Antikainen's arrest and campaign, for instance, A. E Upton, The Communist Parties of Scandinavia and Finland, London: Weidenfeld \& Nicolson, 1973, pp 202-3.

24 See, for instance, Nordens Dimitrov Antikainen, Stockholm 1935; Harry Pollitt, 'The political background of the Antikainen trial', Labour Monthly, September 1936.

25 Oikeusmurha. Antikainen pelastettava, pp 22-40; Nordens Dimitrov Antikainen, pp 3-7, 13-30.

26 Oikeusmurha, p2; on Antikainen's background, N. Parkkari, Nuoret taistelun tiellä. Suomen vallankumouksellinen nuorisoliike 1900-1944, Kuopio: Kansankulttuuri, 1970, p 292.

27 Oikeusmurha, pp2-3; O. V. Kuusinen, Antikaisen juttu, n.d.

28 Kuusinen, Antikaisen juttu.

29 Tumarkin, Lenin Lives!, p 249; Brooks, Thank You, p 61.

30 LaPorte and Morgan, 'Kings', pp 131-2, 135-6.

31 K. Rentola, Kenen joukoissa seisot? Suomalainen kommunismi ja sota 1937-1945, Juva: WSOY, 1994, p 365.

32 M. Tiilikainen, 'Toivo Antikainen - peloton taistelija, lahjakas ihminen' in SKP Taistelujen tiellä. Vuosikirja 1. SKP: Oulu, 1945, pp 50-5; T. Lehen, 'Toivo Antikainen ja hänen oikeusjuttunsa in SKP Taistelujen tiellä 1948. Vuosikirja IV, Helsinki: SKP, 1948, pp 133-61.

33 On Leino, see for instance, Rentola, Kenen joukoissa, pp 514-34; Rentola, Niin kylmää että polttaa. Kommunistit, Kekkonen ja Kreml 1947-1958, Keuruu: Otava, 1997, pp 21-32.

34 On Kuusinen's career, see J. H. Hodgson, Otto Ville Kuusinen. Poliittinen elämäkerta, Helsinki: Tammi, 1975.

35 The description on Kuusinen's celebration is based on Tauno Saarela, 'Otto Ville Kuusinen Commemorated' in Juhana Aunesluoma and Pauli Kettunen (eds), The Cold War and the Politics of History, University of Helsinki, 2008, pp 151-68.

36 KA (archive of the SKP), instruction letters 1951, Educational department to educational secretaries of the districts 15 September 1951.

37 'Lahjojen ja tervehdysten tulva jatkuu', Työkansan Sanomat (henceforth TS), 2 October 1951; 'SKP:n lähetystö matkusti tervehtimään O. W. Kuusista', TS, 3 October 1951.

38 'O.W Kuusisen katu Jyväskylään!', Keski-Suomen Työ, 4 October 1951.

39 Kevin Morgan, Harry Pollitt, Manchester: Manchester University Press, 1994 edn, pp 163-4. 
40 V. Pessi, 'Otto Wille Kuusinen 70-vuotias' in Demokraattisen kansan kalenteri 1951, Helsinki: SKDL 1950, p 68; I. Lehtinen, 'Työväenluokan voiton johtaja' in SKP Taistelujen tiellä 1952. Vuosikirja VIII, Helsinki: SKP 1952, pp 84-5; A. Äikiä, 'Lukijalle' in Kuusinen, Kansainvälisiä, p 12.

41 'Työväenliikkeen kunniakkaat perinteet', TS, 5 October 1951; A. Äikiä, 'Sosialistisen työväenliikkeemme suuri kunniaveteraani Otto Wille Kuusinen' in SKP Taistelujen tiellä 1948. Vuosikirja IV, Helsinki: SICP, 1948, p 122.

42 'Toveri Otto Wille Kuusinen 70-vuotias', Kommunisti 9, 1951, p468; Pessi, 'Otto Wille Kuusinen 70-vuotias', p 62.

43 'Marxin-Engelsin-Leninin ja Stalinin aatteiden suurin suomalainen lipunkantaja', TS, 5 October 1951; Äikiä, 'Sosialistisen työväenliikkeemme', p120; Pessi, 'Otto Wille Kuusinen 70-vuotias', pp 62-3; Lehtinen, 'Työväenluokan voiton johtaja, p86; 'Toveri Otto Wille Kuusinen 70-vuotias', p 471; S. Suvanto, 'O.V. Kuusinen kirjallisen tuotannon esittelyä, Kommunisti 9, 1956, pp 456-66.

44 'Toveri Otto Ville Kuusinen', TS, 4 October 1951; 'Marxin-Engelsin-Leninin ja Stalinin aatteiden suurin suomalainen lipunkantaja, TS, 5 October 1951; T. Lehen, 'Otto Wille Kuusisen taistelu oikeistososialidemokratiaa vastaan', Kommunisti 9, 1951, pp 483-9.

45 'Toveri Otto Wille Kuusinen 70-vuotias', pp 465-74; E. Parkkari, 'Otto Wille Kuusinen - SKP:n rautainen perämies', in SKP Taistelujen tiellä 1945. Vuosikirja I. Oulu: SKP 1945, pp 28-33.

46 On Kuusinen's draft of constitution, see for instance O. Rinta-Tassi, Kansanvaltuuskunta punaisen Suomen hallituksena, Helsinki: VAPK, 1986, pp 323-30.

47 On Manner, see for instance, J. Paastela, Finnish Communism under Soviet Totalitarianism. Oppositions within the Finnish Communist Party in Soviet Russia 19181935, Helsinki: Kikimora Publications, 2003, pp 135-7, 253-309.

48 Jan C. Behrends, 'Exporting the leader: the Stalin cult in Poland and East Germany 1944/45-1956' in Leader Cult, pp 171-2.

49 'Suuren isänmaanystävän ja rauhantaistelijan merkkipäivä; 'O. W. Kuusinen - suuri isänmaanystävä ja kansojen veljeyden esitaistelija', TS, 4 October 1951; T. Lehen, 'O. W. Kuusisen ajatuksia' in SKP Taistelujen tiellä 1951. Vuosikirja VII, Helsinki: SKP 1951, pp 22, 30; Äikiä, 'Lukijalle', p12; M. Ryömä, 'Otto Wille Kuusinen Suomen ja Neuvostoliiton kansojen ystävyyden esitaistelijana', Kommunisti 9, 1951, pp 475-82.

50 'Toveri Otto Wille Kuusinen', TS, 4 October 1951; see also Äikiä, 'Sosialistisen työväenliikkeemme’, pp 131-2; Ryömä, 'Otto Wille Kuusinen Suomen', p 478.

51 R. P(almgren), 'O. W. Kuusinen 65 vuotta', Vapaa Sana (1/S), 4 October 1946; 'R. Palmgren, O.V.K', VS, 4 October 1951; on Palmgren in 1939, e.g. K. Kalemaa, Raoul Palmgren - suomalainen toisinajattelija, Helsinki: Tammi, 1984, pp 112-15.

52 'Toveri Otto Wille Kuusinen', TS, 4 October 1951. 
53 'Tervehdyksemme'; M. Ryömä, 'Puolueemme ansioitunut johtaja', TS, 4 October 1946.

54 Saarela, 'Kuusinen commemorated', pp 162-3.

55 M. R(yömä), 'O. W. Kuusinen 75 vuotta', TS, 4 October 1956.

56 Saarela, 'Kuusinen commemorated', p 155.

57 Saarela, 'Kuusinen commemorated', p 157.

58 J. Renkama, Ideology and Challenges of Political Liberalisation in the USSR, 19571961. Otto Kuusinen's "Reform Platform", the State Concept, and the Path to the 3rd CPSU Programme. Helsinki: SKS 2006, pp 145-54.

59 Saarela, 'Kuusinen commemorated', pp 159, 162.

60 Saarela, 'Kuusinen commemorated', p 163.

61 Helsingin kadunnimet. Toinen korjattu painos. Helsinki: Helsingin kaupunki 1992, pp 120, 135.

62 Rentola, Niin kylmää että polttaa, p 273. Tiutinen, a district in Kotka, was bombed heavily 1943 during the War.

63 J. Suomi, Kriisien aika. Urho Kekkonen 1956-1962. Keuruu: Otava, 1992, pp 154-5; J. Nevakivi, Miten Kekkonen pääsi valtaan ja Suomi suomettui. Keuruu: Otava, 1996, pp 141-5.

64 See for example Behrends, 'Exporting the leader', p 165.

65 'SKP:n pääsihteeri, toveri Ville Pessi 50-vuotias', TS, 23 March 1952; on the poem, Pentti Lahti, 'Laulu teräksestä, TS, 23 March 1952; on congratulations, "'Sinun kanssasi ja johdollasi”, TS, 25 March 1952; 'Onnitteluja toveri Pessille’, TS, 26 March 1952.

66 See Joni Krekola, Stalinismin lyhyt kurssi. Suomalaiset Moskovan Lenin-koulussa 1926-1938, Helsinki: Suomalaisen Kirjallisuuden Seura, 2006, pp 368-9, 428.

67 SKP:n pääsihteeri, toveri Ville Pessi 50-vuotias, TS, 23 March 1952.

68 Sulo Suvanto, 'Toveri Ville Pessi työväenluokan yhtenäisyyden rakentajana' and SKP:n pääsihteeri, toveri Ville Pessi 50-vuotias, TS, 23 March 1952.

69 'Hertta Kuusinen 50-vuotias'; 'Kommunisti ja rauhantaistelija Hertta Kuusinen 50-vuotias', TS, 14 February 1954.

70 'Aimo Aaltonen 50-vuotias', TS, 9 September 1956.

71 Saarela, 'Kuusinen commemorated', pp 156, 165-8. 


\section{Kuusinen vs. Mannerheim \\ - Finnish leader cults in comparison}

1918 was a turning point for the lives of Carl Gustaf Emil Mannerheim (1867-1951) and Otto Ville Kuusinen (1881-1964). Mannerheim, who was born in Finland in 1867 but spent the years 1887-1917 as an officer in the Imperial Chevalier Guard and in the Imperial Russian Army, returned to Finland in December 1917 and became in January 1918 the commander in chief of the white army. Otto Ville Kuusinen who had made career as a social democratic newspaperman and a member of parliament became a member in the Red government in January 1918. As the Civil War between Whites and Reds ended in the defeat of the Reds, Kuusinen escaped to Soviet Russia and lived - with short intervals in Finland and Swden in 1919-21 - the rest of his life in Soviet Russia and the Soviet Union and became a prominent functionary in the Communist International in 1921-43 and in the Communist Party of the Soviet Union in the late 1950s. Mannerheim for his part stayed in Finland and became the commander in chief of the Finnish army during the Winter War in 1939-40 and the Continuation War in 1941-44 and was the president of Finland from August 1944 to March 1946.

Both were admired by various groups of people during their lifetime. That became obvious during their birthdays, and a certain leader cult of both was created. In this article I study the celebration of Mannerheim and Kuusinen during their $70^{\text {th }}$ and $75^{\text {th }}$ birthdays in 1937 and 1942 and in 1951 and 1956 respectively. 


\section{Celebrations}

The celebrations differed in many ways, but the most fundamental difference was the fact that Mannerheim was present, Kuusinen not. In both cases the $70^{\text {th }}$ birthday was more bombastic than the occasion five years later. In Mannerheim's case that was mainly due to the war, while diminishing of Kuusinen's celebration was connected to Khrushchev's disclosures about Stalin and his personal cult in February 1956.

In 1937 the Mannerheim celebration was concentrated in Helsinki; Mannerheim's home in Kaivopuisto, the Great Square, and Messuhalli (Fair exhibition hall) were the main forums of the festivities. Although the military parade on the Great Square, in the centre of the Helsinki, was an important official event during the birthday, the celebration got the character of civic festivities; the programme of the birthday was characterized by congratulation calls of various right wing and military organisations at Mannerheim's home and by a feast organised by Suojeluskunnat, the para-military organisation, in Messuhalli. ${ }^{1}$

In 1942 the congratulation calls of various civic organisations were not as central in the festivities, although there was a reception at Mannerheim's home in Helsinki. Mannerheim himself was, however, at his general headquarters in Mikkeli, and the main part of the festivities took place there. In 1942 the role of the state was also much more evident; the adresses of the president, government and parliament were in the centre of the festivities. The main presents were also given by state organs; the president and the government bestowed the title of Finland's Marshal on Mannerheim and pronounced his birthday, the $4^{\text {th }}$ of July, as a general day of the armed forces and a flag day, the parliament donated the house where Mannerheim had lived in Kaivopuisto to his ownership. There was another new aspect in Mannerheim celebrations in 1942 - the trade union movement presented their congratulations to Mannerheim - and before many military organisations. Thus Mannerheim was in 1942 turned from a right wing celebrity to that of the whole Finnish people. ${ }^{2}$ 
Kuusinen's celebration could not get state character, at least not in Finland - it was a civic festivity organised by communists. In that respect it reminded of Mannerheim's birthday in 1937. Kuusinen's celebration did not, however, include any outdoor parades but was restricted in various festive meetings organized by communists indoors. In 1951 these meetings were, however, organised around the country which was different compared to Mannerheim's celebration. In Helsinki the birthday festivities took place in Messuhalli, the same place which had witnessed Mannerheim's birthday in 1937. A special reception was also organised so that the organisations and members of the movement could deliver their gifts and congratulations to Kuusinen. As he was not present, the leaders of the SKP received the gifts. Kuusinen's $75^{\text {th }}$ birthday in 1956 was not as important an occasion; there were no festive meetings. In 1961, during Kuusinen's $80^{\text {th }}$ birthday, Finnish communists had found a balance and organised modest festive meetings. ${ }^{3}$

The official status of Mannerheim's celebration gave him much more publicity than the party status of Kuusinen's celebration. All the newspapers covered Mannerheim's birthdays with large articles and great amount of photographs, while Kuusinen's birthdays were remembered only in communist newspapers. During Mannerheim's birthdays blue-white colours were flying everywhere ${ }^{4}$, while Kuusinen's followers had to content with red flags in their indoor meetings. Communists could not dream of a radio broadcast on Kuusinen, while during Mannerheim's $75^{\text {th }}$ birthday in 1942 the radio programme of the day was entirely dedicated to Mannerheim. ${ }^{5}$ In 1937 a special stamp in two millions copies was created in order to honour Mannerheim's $70^{\text {th }}$ birthday. ${ }^{6}$ In 1937 some of the restaurants in Helsinki advertised a banquet in honour of Mannerheim. ${ }^{7}$ Also some shops put Mannerheim's picture with blue-white colours in the background in their display windows. ${ }^{8}$ Those celebrating Kuusinen could not get him that kind of publicity. 
The status was also obvious in the presents Mannerheim and Kuusinen received. While Mannerheim got an honorary title and a house from the state, Kuusinen received flags, handicrafts and various articles from Finnish communist organisations and members. The difference was manifest also in the fact that a central street in Helsinki was renamed according to Mannerheim in $1942^{9}$ but the authorities in Jyväskylä, Kuusinen's school town, turned down the proposal of naming a street according to him in $1951 .{ }^{10}$

There were similarities, too. A typical characteristic of the festivities concerning Mannerheim and Kuusinen was the publication of their texts. In Mannerheim's case that was very significant in 1942 when Anni Voipio published her book Suomen sotamarsalk$k a^{11}$ and an edited book Sotamarsalkka Mannerheim 75 vuotta came out. The latter expressed the high-esteem of Mannerheim by its writers who included President Risto Ryti, Ex-President Per Evind Svinhufvud, Prime Minister Jukka Rangell, Foreign Minister Rolf Witting, Speaker of the Parliament Väinö Hakkila, Field Marshal Hermann Göring and Crown Prince Carl from Sweden among others. ${ }^{12}$ A collected volume of Mannerheim's orders of the day from 1918 to 1942 was published in 1942 in order to demonstrate his high morality during his career as a soldier. ${ }^{13}$ Mannerheim's diaries from his ride across Asia in 1906-08 were published as early as $1940 .{ }^{14}$

The publication concerning Kuusinen was more modest; there were no biographies or collected works on Kuusinen in 1951 or 1956. In 1951 the collection of Kuusinen's speeches and articles from 1918 to 1949 was published in a book Kansainvälisiä kysymyksiä (International issues) ${ }^{15}$.

It was only after his death that a large collection of his speeches and articles was published in the Soviet Union. ${ }^{16}$ A collection of articles by representatives of various communist parties - for instance German Walter Ulbricht, British Rajani Palme Dutt, French Jacques Duclos, Austrian Friedl Fürnberg, Swede Hilding Hagberg and Norwegian Emil Lövlien - was put forth in Finland in 1971 in order to demonstrate Kuusinen's internationalism. ${ }^{17}$ 


\section{'White general' and 'statesman'}

The change of the characterisation of Mannerheim between 1937 and 1942 was substantial. In 1937, despite the participation of the government, president and parliament in the celebrations, Mannerheim was still pronouncedly a soldier. That was evident in the programme of the celebrations; the military parade and congratulations by various military and para-military organizations formed its main part. The newspapers, especially the right wing newspaper Uusi Suomi, defined Mannerheim as a soldier. ${ }^{18}$

In 1942 the characterisation of a soldier was still present, but there was not such a need to talk about his military skills; the recent events, the Winter War in 1939-40 and the new war which had started in 1941, were enough to remind of them. So was also the constant talk about Mannerheim as a field marshal. In 1942 Mannerheim was portrayed also as a statesman; he was the man who had taken the task of guiding "the development of the country" and laid out "important solutions" in difficult moments. There was a tendency to turn his merits in the military field as those of a statesman. Thus Mannerheim's constant worry about Finland's defense capacity was a proof of his far-sightedness. He had also given the ideological content for the battle during the Winter War. ${ }^{19}$

The statesman Mannerheim was also given the merits of uniting the Finnish people. It was argued that Mannerheim had not only talked about the unity but also taken initiatives and done deeds which created basis for it. It was also argued that after the Civil War in 1918 Mannerheim had tried to be conciliatory towards the Reds and later on done everything in order to overcome the division of the people and to heal up the wounds of the Civil War. ${ }^{20}$ Most practical Mannerheim's deeds were in the child welfare and in the foundation of Mannerheim League for Child Welfare in $1920 .{ }^{21}$

According to the newspapers, Mannerheim had achieved the status of a statesman by keeping himself above the everyday disputes and interests of the parties and regarding only the success of 
the country as his polestar. Unlike the rest of the Swedish-speaking aristocrats in Finland, Mannerheim had grown fast with the Finnish people, and had learnt to understand its needs, wishes and spiritual life. As a statesman and soldier Mannerheim had also used his authority in such a way that he had achieved a unanimous respect in all the circles of the country. Thus the chief in command in the liberation war had begun to symbolise the unity of the people. In 1942 it was usual to emphasize that the whole people had gradually learnt to respect and trust Mannerheim, and he had become "a common caretaker of all the citizens".22

The celebrations indicated that Mannerheim's greatness was above all seen in relation to Finland's history. Mannerheim was portrayed as a great man who with his authority and capabilities had entered the scene in order to solve the problems of the country in difficult moments. In 1937 Mannerheim was "the famous liberator of the country", "the white commander in chief in the Liberation War" or just "the white general". ${ }^{23}$ In 1942 the defense of Finland's independence and the unity of the nation were in the centre of Mannerheim's portrait. ${ }^{24}$

There was a clear tendency to portrait Mannerheim of the waryears to the history and forget all the difficult questions about Mannerheim's relation to Reds, to democracy or to Soviet Russia. Mannerheim's long service in the Russian army was also a sore point to the painters of the nationalist image of Mannerheim, and there was a certain need to explain it. Thus it was usual to convince that even in Russia Mannerheim had, due to his patriotic family traditions and high sense of honour, preserved himself as a proud Finnish man, and portray Mannerheim in 1890s or 1917 as Mannerheim in $1942 .{ }^{25}$ Thus it was possible to admit that Mannerheim had learnt his military skills in foreign battlefields and to publish pictures on him as an officer of Imperial Chevalier Guard and as a commander of an Ulan regiment. ${ }^{26}$ 


\section{'Eminent theoretician' and 'iron helmsman'}

In the communist movement nation, nationalism and various deeds for the independence of the country were not as important. It rather emphasized internationalism, theory and party. Thus Otto Ville Kuusinen was seen in relation to theoreticians of the labour movement, especially those of the communist movement. ${ }^{27}$ In the official vocabulary of the SKP in 1951 Kuusinen was characterised as 'the student of Marx, Engels, Lenin and Stalin', 'the greatest Finnish champion for the ideas of Marx, Engels, Lenin and Stalin' or 'the greatest Finnish flag-bearer for the victorious ideas of Lenin and Stalin' or 'one of the most prominent theoreticians in the international communist movement'. In the following years Stalin's name was dropped out and the other names replaced by a more general reference to marxist-leninist ideas. It also became typical to emphasize how creative Kuusinen had been. The change was due to the revelations about the Stalin cult by Khrushchev, but also to the fact that Kuusinen had established a name for himself in the field of theory after The Fundamentals of Marxism-Leninism, written under his leadership, had come out in $1959^{28}$.

The image of Kuusinen as a theoretician was so strong that it was very difficult to argue that he was also a politician and a prominent man of action. Besides the respect for the priority of theory in the communist movement, this was also due to writers' difficulties to express how his prominence had manifested itself. So it was common to write about Kuusinen's deeds in general terms or to emphasize certain events.

Kuusinen's merits in politics were often found in the fight against war and fascism and in the defence of democracy. It was, however, more usual to present examples of his actions in relation to the history of the Finnish labour movement, to emphasize his role in the People's Deputation in 1918, even to regard him as its leading character. It was, however, more common to say that Kuusinen was one of the founders of the SKP or, stressing Kuusinen's role, to say that the SKP, 'the party of a new type', was 
founded 'on the initiative of Kuusinen'. It was also common to argue that the party had worked under his guidance in the 1920s and 1930s or to say more modestly that Kuusinen had helped the party on various occasions.

Kuusinen's guidance was often seen in questions regarding the attitude of communists to other political forces, especially social democrats. In 1951 it was emphasized how Kuusinen had taught that the working class could fulfil its historical task only by expelling the betrayers of the class struggle. Thus he had been active in the fight against the right-wing social democrats. In Коттиnisti, the theoretical organ of the SKP, the fight for the leninist line against various opportunist deviations was also considered an important part of Kuusinen's political legacy.

Otherwise Kuusinen's actual deeds were not discussed in detail, but there was a tendency to study even his pre-communist activities through communist glasses; his work in the parliament was seen in the context of the importance of mass activities and the draft of the constitution written by him in 1918 was equated with the dictatorship of the proletariat, although, emphasizing the significance of parliament and referendum, the draft was much more in harmony with the ideas of western marxism ${ }^{29}$.

Short biographical articles written about him increased the impression that Kuusinen was the only leader of the SKP. This idea was also strengthened by the fact that nobody wanted to remember Kullervo Manner, who had been the leader of the People's Deputation in 1918 and the chairman of the SKP in 1920-1934, but who had been labelled as a deviationist and dismissed ${ }^{30}$. This impression was also furthered by the use of the words 'first', 'active, 'most skilful' and 'credited' - all in all Kuusinen was 'the iron helmsman of the SKP'. In October 1951 Kommunisti gave the impression that Kuusinen had been the first in every action and everything was done under his leadership or his initiative.

The official line of the SKP was mainly written by persons who had come to know Kuusinen as a Communist International functionary and one of the leaders of the SKP, and who had worked with him in the SKP. Thus it was natural for them to emphasize 
Kuusinen's role in regard to the SKP. But their characterizations were also strongly influenced by their living in the Soviet Union and their adaptation to the celebration of communist leaders and to communist history writing initiated by Stalin in the early 1930s. That commitment led them to picture Kuusinen as a theoretical and political star of the communist movement and to give the impression that the history of Kuusinen was also that of the party.

\section{Patriotism and internationalism}

There were also attempts to see Kuusinen as a great actor in Finnish history, and the communists argued for his merits as the builder of peace between Finland and the Soviet Union. ${ }^{31}$ Thus he had fought for the independence of Finland from the beginning of the $20^{\text {th }}$ century but at the same time realised the importance of the friendship between the peoples of Finland and the Soviet Union. He was the pioneer and had done more than any other Finn in this field. It became usual for the Finnish communists to claim that the war between Finland and the Soviet Union would not have broken out in 1939 and all the controversial issues would have been solved peacefully, if Kuusinen's advice had been followed.

Praising Kuusinen's patriotism was a controversial issue; for the bourgeoisie the establishment of the Terijoki government during the Winter War in November 1939 or participation in the war propaganda against Finland during the Continuation War in 1941-4 rather symbolised the Soviet origin and interests of Kuusinen and the whole Finnish communist movement. The depiction of Kuusinen as a 'peace fighter' implied criticism towards the nationalist perspective of bourgeois Finland. According to the communists, a new kind of perspective based on internationalism and the marxist-leninist principles was needed. 
After the Second World War the interest in peace reflected, of course, the wish to avoid the recurrence of its horrors, but in the divided world of the Cold War it was also important to present oneself as a bearer of peace. Peace became also an important characteristic in the communist leader cult, and Stalin was called 'a warden of peace' who would prevent the outbreak of the new war ${ }^{32}$. The question of peace left its imprint also on the image of Kuusinen presented by the Finnish communist movement; he was regarded as a great patriot and fighter for the brotherhood of nations.

The depiction of Kuusinen's eminence in the fields of theory and politics and his connections to the leaders of the international labour movement was also an attempt to say that Kuusinen was an important Finnish person. Finnish communists also wanted to launch a new concept of great men and of history; great men were those who were able to perceive the historical and social forces of development and interpret the needs of the masses. Kuusinen filled these requirements since he had taken into account the needs of the Finnish people but had also been an example for other peoples.

Although Mannerheim was mainly portrayed in relation to Finland, there were international references in his celebration, too. They were modest in 1937, but even then right wing newspapers tried to prove Mannerheim's international fame by publishing statements from foreign officers - mainly generals - about Mannerheim's skills as a military leader and as a statesman. ${ }^{33}$

In 1942 it was more customary to add that Mannerheim had led Finland's armies in battles that had great significance beyond Finland; in 1918 he had stopped the march of the communists to Northern Europe, from 1939 he had been a shield against "the threatening forces from the east who wanted to drown the whole continent into chaos" and thus done a lot in order to preserve European and Western civilization. ${ }^{34}$ As an attempt to prove the gratitude of Europe the newspapers published news about Mannerheim celebrations in Germany and Sweden and repeated the praising words of foreign newspapers. ${ }^{35}$ 
The greatest international triumph was, however, the visit of German Reich Chancellor Adolf Hitler at Mannerheim's general quarters in Mikkeli. As the Reich Chancellor had seldom left his headquarters during the war $^{36}$, the visit was considered a great honour and a historical event not only to Mannerheim but also to the Finnish people. The visit was also regarded as a proof of the cordiality concerning the alliance between Germany and Finland and of the fact that both Mannerheim and Hitler had fought against communism and bolshevism for two decades. ${ }^{37}$ Mussolini's congratulation telegram was not regarded as important. $^{38}$

The international significance of Mannerheim and Kuusinen was also indicated by the medals of honour they received. In his $70^{\text {th }}$ birthday Mannerheim was awarded with the Grand Cross of Red Cross, the highest medal of honour in Germany which was previously given only to crowned monarchs - and Mussolini. ${ }^{39}$ Five years later he received the German Knight Cross of the Iron Cross. ${ }^{40}$ Kuusinen on his part was awarded the Order of Lenin in the Soviet Union in 1951 and the title of Hero of Socialist Labour in $1961 .^{41}$

\section{Horseman and scientist}

It was usual to portray great men as skillful in almost all fields they touched. In that respect Mannerheim was not an exception. During his $70^{\text {th }}$ and 75th birthday it was customary to remind of his skills on other fields. Horses were connected to Mannerheim's career as a soldier, and during his birthdays he was advertised as a prominent rider and an expert in riding. Riding tour through Asia in 1906-08 was a proof of the former, the encouragement and support of the Finnish Riding Association of the latter. ${ }^{42}$ The wildlife hunting, the other hobby of Mannerheim, was not advertised as strongly, although the newspapers published Mannerheim's memoirs about tiger hunt in India in the 1920s. ${ }^{43}$ 
Kuusinen's free time hobbies were not presented as often as those of Mannerheim. Kuusinen, the theoretician, was not pictured as a sportsman or an outdoor person, although Arvo Tuominen reminded of Kuusinen's habit of doing gymnastics at home ${ }^{44}$. It was, however, only after Kuusinen's death that pictures of Kuusinen skating or playing volleyball reached the publicity.

Mannerheim was not portrayed only as an outdoor man. On the basis of his riding tour in Asia in 1906-08 and the diary based on the observations from that tour Mannerheim was in 1937 characterised as an explorer who had first-class gifts as a scientist. ${ }^{45}$

Ernst Linder, a close friend of Mannerheim, emphasised Mannerheim's ability's in writing and regarded his declarations in 1918 as masterpieces in order to heighten the self-esteem of the young army and to lift the enthusiasm and willingess of the young men to sacrifice themselves. ${ }^{46}$

The merits of Mannerheim as an author were put forth especially in 1942 as V.A. Koskenniemi, 'the Poet Laureate of white Finland, admired the spirituality and universalism of interest in Mannerheim's texts in his diary during his ride through Asia. In Koskenniemi's opinion, the diary from the ride, anticipated the brilliant prose his orders of the day and speeches had demonstrated. ${ }^{47}$

Kuusinen had also been an active writer but that had often taken place in a collective. Thus it was not usual to claim anything about Kuusinen's writing talents. Kuusinen's cultural interests were also shadowed by those in theory and party, and they were not pointedly picked up during his birthdays. He was, though, remembered for his interest in music and his discussions on modern poetry with Elmer Diktonius, the Swedish-speaking Finnish poet, in 1920, and especially for his interest in Kalevala, and his studies on $i^{48}$. Kuusinen's cultural interests were, however, more prominent only after his death. 


\section{Tall nobleman and tiny tailor's son}

The greatness of Mannerheim was often connected with his nobility background. As a member in an old cultural family he was regarded as tailor-made to various tasks of representing both at home and abroad. ${ }^{49}$ The newspapers declared that he had inherited his talents and all-round interests from his father and mother. Joy of life, behaviour of a man of the world and strong love for traditions came from his father, while complaisance and sense of justice and duty took after his mother. ${ }^{50}$ V.A. Koskenniemi was more practical as he saw soldier career, self-sacrifying patriotism, exceptional talents and practical scientific interests as family tradition. ${ }^{51}$ In the labour movement it was customary to emphasize the proletarian background of the leaders, but Kuusinen was rather seldom pictured in such a light, and his background as a son of a poor tailor was not particularly highlighted ${ }^{52}$.

In the nationalist tradition it was obviously easier to speak of the appearance of the leaders than in the labour movement. So, the right wing newspapers referred to Mannerheim's handsome and manly appearance or to his chivalrous presence ${ }^{53}$, but communist newspapers did not mention anything about Kuusinen's appearance. The pictures of Mannerheim took advantage of his tallness; Mannerheim was $190 \mathrm{~cm}$ tall and the pictures usually presented him in full-length ${ }^{54}$, while small Kuusinen got only his face in the pictures. There were, of course, much more pictures about Mannerheim than Kuusinen in the newspapers, although Kuusinen's face could cover the whole front page of a communist paper $^{55}$.

Although Mannerheim was present during his anniversaries and Kuusinen was not and although Mannerheim's celebration got much more publicity, there were common characteristics in their celebration. The format of the festivities was mainly similar; festi- 
ve meetings, various presents, articles in newspapers, collections of articles by the birth day heroes, books for them. The occasions were also mainly civic festivities, although the state had a significant role during Mannerheim's birthday in 1942. Mannerheim's celebration was also more military in its outlook - Kuusinen's celebration did not include any outdoor parades.

Mannerheim was closely connected with the nationalist interpretation of Finland and its fight against the eastern neighbour, while the service in the international communist movement was regarded as Kuusinen's merits. The attempts of the Finnish communists to break the nationalist interpretation by arguments that Kuusinen had tried to help Finland were not convincing. The habit of the communist movement to give priority to theory gave Kuusinen such a strong image as a theoretician that it was difficult to consider him also as a politician and a prominent man of action. The picture of Mannerheim was also in other respects more diversified - besides being a soldier and a statesman he was also an explorer, rider - an outdoor man - and an author. Thus, it was obviously much easier for the Finns to vision Mannerheim's significance than Kuusinen's.

Although Mannerheim's celebration was in decline especially after putting up of his rider statue in the center of Helsinki in $1960^{56}$, Kuusinen, whose celebration was probably at its heights in the $1970 \mathrm{~s}^{57}$, could not reach Mannerheim's popularity. Thus, it was not very surprising that in a voting concerning Great Finns, organized by Yleisradio, the Finnish broadcasting company, in 2004, Mannerheim became number one, while Kuusinen was $38^{\text {th }} .58$

Paper presented at the European Social Science History Conference Gent 12-17 April 2010 


\section{Notes}

1 'Sotamarsalkka Mannerheimin 70-vuotispäivä, Helsingin Sanomat (HS) 3 June 1937; 'Sotamarsalkka Mannerheimin 70-vuotispäiväjuhlallisuudet', HS 4 June 1937.

2 'Päivä maamme historiaan'; 'Historiamme suurin sotilas'; 'Sotamarsalkan kodissa juhlapäivänä, HS 5 June 1942; Suomen marsalkka, Uusi Suomi (US) 5 June 1942 pk; 'Suomen marsalkan merkkipäivänä, US 5 June 1942.

3 Tauno Saarela, 'Otto Ville Kuusinen Commemmorated', in The Cold War and the Politics of History. Edited by Juhana Aunesluoma and Pauli Kettunen. Edita \& University of Helsinki, Helsinki 2008, 153-155 (PDF, see https://helda.helsinki.fi/handle/10224/4646).

4 "'Te uskoitte minuun ja minä luotin suomalaiseen talonpoikaan"', US 5 June 1937.

5 'Kotimaasta tänään', HS 4 June 1942.

6 'Mannerheimin juhlapostimerkkejä, HS 4 June 1937.

7 HS 4.6.1937; US 4.6.1937.

8 '"Te uskoitte minuun ja minä luotin suomalaiseen talonpoikaan", US 5 June 1937.

9 'Mannerheimintie Heikinkadun ja Turuntien uudeksi nimeksi', HS 4 June 1942.

10 Tauno Saarela, 'Dead martyrs and living leaders: the cult of the individual within Finnish communism', Twentieth Century Communism. Issue 12009. Communism and the leader cult, 38, 42.

11 Anni Voipio, Suomen sotamarsalkka. WSOY: Porvoo 1942.

12 Sotamarsalkka Mannerheim 75 vuotta kesäkuun 4 päivänä 1942. Toimittaneet Kaarlo Hildén, Ragnar Numelin, Birger Fagerström. Suomen kirja: Helsinki 1942.

13 Puhtain asein. Sotamarsalkka Mannerheimin päiväkäskyjä vuosilta 1918-42. Toim. Einari Kaskimies. Otava: Helsinki 1942.

14 C. G. E. Mannerheim, Matka Aasian halki. Päiväkirja matkalta Kaspianmeri-Peking. 1. Matka Pietarista Gutsheniin 6 päivästä heinäkuuta 19063 päivään syyskuuta 1907; 2. Matka Gutshenista Kalganiin 5 päivästä syyskuuta 190720 päivään heinäkuuta 1908. Suomen kirja: Helsinki 1940.

15 O. W. Kuusinen, Kansainvälisiä kysymyksiä. Kansankulttuuri: Helsinki 1951.

16 O. W. Kuusinen, Valitut teokset (1918-1964). Edistys: Moskova.

17 Otto Wille Kuusinen - suomalainen internationalisti. Toimittanut MarjaLeena Mikkola. Kansankulttuuri: Helsinki 1971.

18 'Sotamarsalkka Mannerheimin 70-vuotispäivä, HS 3 June 1937; 'Sotamarsalkka Mannerheimin 70-vuotispäiväjuhlallisuudet', HS 4 June 1937; 'Sotamarsalkan syntymäpäivänä, US 4 June 1937 editorial. 
19 'Sotamarsalkan juhlapäivänä, HS 4 June 1942 editorial; 'Historiamme suurin sotilas', HS 5 June 1942; 'Sotamarsalkan juhlapäivänä; E. O., 'Sotapäällikkö ja valtiomies', US 4 June 1942.

20 'Sotamarsalkan juhlapäivänä, HS 4 June 1942 editorial; 'Historiamme suurin sotilas', HS 5 June 1942; 'Sotamarsalkan juhlapäivänä, US 4 June 1942.

21 'Suomen lasten suurin auttaja', HS 4 June 1937; 'Mannerheim ja Suomen lapset', US 4 June 1937.

22 'Sotamarsalkan juhlapäivänä, HS 4 June 1942, editorial; 'Sotamarsalkka Mannerheim 75-vuotias', HS 4 June 1942; V. A. Koskenniemi, 'Sotamarsalkkamme', US 4 June 1942.

23 'Kunniaa miehelle', HS 4 June 1937 editorial; 'Sotamarsalkan syntymäpäivänä, US 4 June 1937 editorial.

24 'Sotamarsalkan juhlapäivänä', HS 4 June 1942 editorial; 'Sotamarsalkka Mannerheim 75-vuotias', HS 4 June 1942; 'Sotamarsalkan juhlapäivänä; Martti Haavio, 'Rintamamies näkee sotamarsalkan', US 4 June 1942; 'Koko kansa juhli Suomen marsalkkaa, US 5 June 1942.

25 'Sotamarsalkan syntymäpäivänä, US 4 June 1937 editorial; 'Sotamarsalkka Mannerheim 75-vuotias', HS 4 June 1942; V. A. Koskenniemi, 'Sotamarsalkkamme', US 4 June 1942.

26 See, e.g. 'Kuvia sotamarsalkan elämästä, HS 4 June 1937; 'Sotamarsalkan juhlapäivänä, HS 4 June 1942.

27 On Kuusinen's assessment, Saarela, ‘Otto Ville Kuusinen', 156-160.

28 On Kuusinen and The Fundamentals, see e.g. Jukka Renkama, Ideology and Challenges of Political Liberalisation in the USSR, 1957-1961. Otto Kuusinen's "Reform Platform", the State Concept, and the Path to the $3^{\text {rd }}$ CPSU Programme. Helsinki. SKS 2006, 145-154.

29 On Kuusinen's draft of constitution, e.g. Osmo Rinta-Tassi, Kansanvaltuuskunta punaisen Suomen hallituksena. Helsinki: VAPK 1986, 323-330.

30 On Manner, for instance, Jukka Paastela, Finnish Communism under Soviet Totalitarianism. Oppositions within the Finnish Communist Party in Soviet Russia 1918-1935. Helsinki: Kikimora Publications 2003, 135-137, 253309.

31 On this, Saarela, 'Otto Ville Kuusinen', 161-163.

32 Jan C. Behrends, 'Exporting the Leader: The Stalin Cult in Poland and East Germany 1944/45-1956, in The leader cult in communist dictatorships. Stalin and the Eastern Bloc. Edited by Balázs Apor, Jan C. Behrends, Polly Jones and E. A. Rees. New York: Palgrave Macmillan 2004, 171-172.

33 See, e.g., M. Weygard, 'Sydämen ja lujan tahdon mies'; G. M. W. Macdonogh, 'Sotamarsalkka Englannissa'; W. A. Douglas, 'Sotamarsalkka Mannerheimin 70-vuotispäivänä'; W. Kirke, 'Valtiomies ja sotilas'; Gösta Törngren, 'Onnentoivotus Suomelle ja sen vapauttajalle', Paul Skoropadsky, 'Vanhan toverin tervehdys', US 4 June 1937.

34 'Sotamarsalkan juhlapäivänä, HS 4 June 1942 editorial;

35 '”Mannerheim on yksimielisyyden symboli"'; US 3 June 1942; 'Sotamarsalkka Mannerheim koko vapautta rakastavan Skandinavian ajatusten kohtee- 
na'; 'Sotamarsalkan 75-vuotispäivä Saksassa'; 'Mannerheim bolshevisminvastaisen taistelun edustavimpia esitaistelijoita', HS 4 June 1942.

36 See, e.g. Ian Kershaw, Hitler. Otava: Helsinki, 2008, 694-695.

37 'Saksan kunnianosoitus', HS 5 June 1942 editorial; 'Saksan johtaja vieraili', US 5 June 1942 editorial.

38 'Mussolinin tervehdyssähkösanoma', US 4 June 1942.

39 'Sotamarsalkka Mannerheim sai eilen Saksan korkeimman kunniamerkin', US 3 June 1937.

40 'Hitler vieraili eilen maassamme', HS 5 June 1942.

41 Saarela, 'Otto Ville Kuusinen', 162-163.

42 Kimo, 'Sotamarsalkka Mannerheimin ratsastajanura', HS 4 June 1937.

43 'Sotamarsalkka Mannerheim kertoo tiikerinmetsästyksestään', HS 30 May 1937.

44 Arvo Tuominen, Kremlin kellot. Muistemia vuosilta 1933-1939. Tammi: Helsinki 1957, 85.

45 G. J. Ramstedt, 'Tutkija ja tiedemies', HS 4 June 1937.

46 Ernst Linder, 'Eräitä Mannerheimin persoonallisuuden piirteitä, US 4 June 1937.

47 V. A. Koskenniemi, 'Sotamarsalkkamme', US 4 June 1942.

48 Raoul Palmgren, 'O.V.K.'; 'Niitä musiikin- ja kirjallisuudenhetkiä en unohda"', Vapaa Sana 4 October 1951.

49 'Kunniaa miehelle', HS 4 June 1937 editorial.

50 'Sotamarsalkka Mannerheim 75-vuotias', HS 4 June 1942; see also Emerik Olsoni, 'Mannerheim-suku', US 4 June 1937.

51 V. A. Koskenniemi, 'Sotamarsalkkamme', US 4 June 1942.

52 On Kuusinen's background, see, e.g., Martti Pakkanen, 'Kyläräätälin poika', in Nuori Otto Ville Kuusinen 1881-1920. Toimittanut Vesa Salminen. Gummerus: Jyväskylä 1970, 11-12.

53 Ernst Linder, 'Eräitä Mannerheimin persoonallisuuden piirteitä, US 4 June 1937.

54 See, e.g., 'Sotamarsalkkamme 70-vuotias', HS 4 June 1937; 'Juhlava ylipäällikkö, HS 4 June 1942.

55 Työkansan Sanomat 4 October 1951.

56 See, e.g., Riitta Konttinen, Suomen marsalkan ratsastajapatsas. Suomen marsalkka Mannerheimin perinnesäätiö: Helsinki, 1989, 11-15, 56-108, 185-199.

57 Saarela, 'Otto Ville Kuusinen', 165-167.

58 Suuret suomalaiset. Otava: Helsinki, 2004, 259; Suuret suomalaiset (http:// yle.fi/vintti/yle.fi/suuretsuomalaiset/tiedotteet/index7429.html?id=15). 


\section{Date and sources of original publications}

Finnish and international communism

National and International in the Communist Movement. Published in Communism: National and International. Edited by Tauno Saarela and Kimmo Rentola. SHS, Helsinki 1998, 15-40.

Finnish communism, Bolshevization and Stalinization. Published in Bolshevism, Stalinism and the Comintern. Perspectives on Stalinization, 1917-53. Edited by Norman LaPorte, Kevin Morgan and Matthew Worley. Palgrave Macmillan, Basingstoke and New York 2008, 188-205.

Comparative Communisms: The Nordic Example. Paper presented in the session Stalinisation and Beyond: Problems of International Communism, European Social Science History Conference, Lisbon, 26 February 2008.

Nordic communists in the Communist International. Published in Regional Cooperation and International Organizations. The Nordic model in transnational alignment. Edited by Norbert Götz and Heidi Haggrén. Routledge, London and New York 2009, 233-247.

American impact on Finnish communism in the 1920s. Published in Labouring Finns. Transnational Politics in Finland, Canada, and the United States. Edited by Michel S. Beaulieu, Ronald N. Harpelle, Jaimi Penney. Institute of Migration, Turku 2011, 50-69.

\section{Cultural communism}

Class struggle in the cemetery. Published in Labour movements. Socialist History 9. Edited by Willie Thompson, David Parker, Mike Waite and David Morgan. London 1996, 82-89. 
Oppressed Worker or Communist Hero? Characters in Finnish communist magazines of the 1920s. Published in Red Lives. Socialist History 21. London 2002, 11-23.

Finnish communist youth and popular music, 1944-1979. Paper presented in the session Cultural communism between national traditions and international impacts, 1918-1989, European Social Science History Conference, Vienna 26 April 2014.

\section{Leader cults}

Dead martyrs and living leaders: the cult of the individual within Finnish communism.

Published in Twentieth Century Communism. Issue one 2009: Communism and the leader cult. London 2009, 30-49.

Kuusinen versus Mannerheim - Finnish leader cults in comparison. Paper presented in the session The cult of communist leaders, European Social Science History Conference, Ghent 14 April 2010 . 
Finnish communism was one of the largest communist movements in Europe. It was born in two countries, Finland and Soviet Russia, and in 1918-1944 active in both of them. It was a movement deeply rooted in Finnish society and the traditions of the Finnish labour movement, but also a movement with strong ties with the Soviets. This collection of articles by Tauno Saarela gives a glimpse of this tension within Finnish communism.

The articles discuss the contacts between the Communist International and Finnish communism, the relations between Finnish and Scandinavian communists, the American impact on Finnish communism. They also touch the importance of cemeteries for Finnish communism, characters in the short stories published in the Finnish communist magazines in the 1920s, and the attitude of the Finnish communist youth towards jazz, rock and roll and pop songs in 1944-1969. The articles address the cult of the individual within Finnish communism, too.

Tauno Saarela is Senior Lecturer in Political History, Department of Political and Economic Studies, University of Helsinki. He is the author of Suomalaisen kommunismin synty 1918-1923 [Birth of Finnish communism, 1918-1923] (1996), Kansan Tahto. Pohjolan työtätekevien lehti (2006), Suomalainen kommunismi ja vallankumous 1923-1930 [Finnish communism and revolution, 1923-1930] (2008), and the co-author of Communism: National and International (1998), Коминтерн и Финляндия 1919-1943 (2003), and several books in Finnish. 